\title{
EWSR1-The Most Common Rearranged Gene in Soft Tissue Lesions, Which Also Occurs in Different Bone Lesions: An Updated Review
}

\author{
Uta Flucke $^{1,2, *}$, Max M. van Noesel ${ }^{2,3}$, Vasiliki Siozopoulou ${ }^{4}\left(\mathbb{D}\right.$, David Creytens ${ }^{5}{ }^{(}$, Bastiaan B. J. Tops ${ }^{2} \mathbb{D}^{\circ}$, \\ Joost M. van Gorp ${ }^{6}$ and Laura S. Hiemcke-Jiwa ${ }^{2}$ (D) \\ 1 Department of Pathology, Radboud University Medical Center, 6525 GA Nijmegen, The Netherlands \\ 2 Princess Máxima Center for Pediatric Oncology, 3584 CS Utrecht, The Netherlands; \\ M.M.vanNoesel@prinsesmaximacentrum.nl (M.M.v.N.); b.b.j.tops@prinsesmaximacentrum.nl (B.B.J.T.); \\ 1.s.jiwa-3@prinsesmaximacentrum.nl (L.S.H.-J.) \\ 3 Division Cancer \& Imaging, University Medical Center Utrecht, 3584 CX Utrecht, The Netherlands \\ 4 Department of Pathology, Antwerp University Hospital, 2650 Edegem, Belgium; vasiliki.siozopoulou@uza.be \\ 5 Department of Pathology, Ghent University Hospital, Ghent University, 9000 Ghent, Belgium; \\ David.creytens@uzgent.be \\ 6 Department of Pathology, St Antonius Hospital, 3435 CM Nieuwegein, The Netherlands; \\ j.van.gorp@antoniusziekenhuis.nl \\ * Correspondence: uta.flucke@radboudumc.nl; Tel.: +31-24-36-14387; Fax: +31-24-36-68750
}

\section{check for} updates

Citation: Flucke, U.; van Noesel, M.M.; Siozopoulou, V.; Creytens, D.; Tops, B.B.J.; van Gorp, J.M.; Hiemcke-Jiwa, L.S. EWSR1-The Most Common Rearranged Gene in Soft Tissue Lesions, Which Also Occurs in Different Bone Lesions: An Updated Review. Diagnostics 2021, 11, 1093. https://doi.org/10.3390/ diagnostics11061093

Academic Editor: Andrea Angelini

Received: 18 April 2021

Accepted: 10 June 2021

Published: 15 June 2021

Publisher's Note: MDPI stays neutral with regard to jurisdictional claims in published maps and institutional affiliations.

Copyright: (C) 2021 by the authors Licensee MDPI, Basel, Switzerland. This article is an open access article distributed under the terms and conditions of the Creative Commons Attribution (CC BY) license (https:// creativecommons.org/licenses/by/ $4.0 /)$.

\begin{abstract}
EWSR1 belongs to the FET family of RNA-binding proteins including also Fused in Sarcoma (FUS), and TATA-box binding protein Associated Factor 15 (TAF15). As consequence of the multifunctional role of EWSR1 leading to a high frequency of transcription of the chromosomal region where the gene is located, EWSR1 is exposed to aberrations such as rearrangements. Consecutive binding to other genes leads to chimeric proteins inducing oncogenesis. The other TET family members are homologous. With the advent of widely used modern molecular techniques during the last decades, it has become obvious that EWSR1 is involved in the development of diverse benign and malignant tumors with mesenchymal, neuroectodermal, and epithelial/myoepithelial features. As oncogenic transformation mediated by EWSR1-fusion proteins leads to such diverse tumor types, there must be a selection on the multipotent stem cell level. In this review, we will focus on the wide variety of soft tissue and bone entities, including benign and malignant lesions, harboring EWSR1 rearrangement. Fusion gene analysis is the diagnostic gold standard in most of these tumors. We present clinicopathologic, immunohistochemical, and molecular features and discuss differential diagnoses.
\end{abstract}

Keywords: EWSR1; soft tissue tumors; bone tumors; pathology; molecular

\section{Introduction}

Ewing sarcoma was molecularly defined by Delattre et al. in 1992 upon the identification of the Ewing sarcoma breakpoint region 1 (EWSR1) located on chromosome 22q12.2 and the term for this gene was coined [1]. EWSR1 is a multifunctional protein ubiquitously expressed in most cell types, indicating diverse roles in physiological cellular processes, including organ development and aging. Genetic and epigenetic pathways are modulated by EWSR1 but the exact mechanisms are still poorly understood [2].

EWSR1 belongs to the FET (also known as TET) family of RNA-binding proteins that also includes Fused in Sarcoma (FUS), and TATA-box binding protein Associated Factor 15 (TAF15) [2]. As a consequence of the multifunctional role of EWSR1 leading to a high frequency of transcription of the chromosomal region where the gene is located, EWSR1 is exposed to aberrations such as rearrangements. Consecutive binding to other genes leads to chimeric proteins inducing oncogenesis. These various somatic genetic rearrangements 
involving EWSR1 result in a fusion of its $\mathrm{N}$-terminal coding region to the C-terminal DNA binding domain of one of several transcription factors. They are reported to act as aberrant transcription factors with the N-terminal domain of EWSR1 as a strong transactivator. The other TET family members are homologous and are involved in strikingly similar translocation events giving rise to the production of structurally similar oncoproteins $[3,4]$.

With the advent of widely used modern molecular techniques during the last decades, it has become obvious that EWSR1 is involved in development of diverse benign and malignant tumors with mesenchymal, neuroectodermal, and epithelial/myoepithelial features [5]. As oncogenic transformation mediated by EWSR1-fusion proteins leads to such diverse tumor types, there must be a selection on a multipotent stem cell level [2].

In this review, we will focus on the wide variety of soft tissue and bone entities, including benign and malignant lesions, harboring EWSR1 rearrangement. Fusion gene analysis is the diagnostic gold standard in most of these tumors. We present clinicopathologic, immunohistochemical, and molecular features and discuss differential diagnoses.

\section{Ewing Sarcoma}

Arthur Purdy Stout and James Ewing were the first to describe this aggressive small, blue round-cell entity in 1918 and 1921, respectively [6-8]. Later on, the chromosomal translocation $(11 ; 22)$ was found by Aurias et al. and Turc-Carel et al. in 1983, the second breakthrough of translocation/fusion-gene associated sarcomas following alveolar rhabdomyosarcoma (ARMS) [9-11]. Subsequently, the fusion gene has been detected as mentioned in the introduction [1], being the genetic hallmark by an otherwise aspecific small blue, round-cell tumor.

Ewing sarcoma, the prototypic round-cell sarcoma, is relatively common in comparison to other small blue round-cell sarcomas. It arises in soft tissue and bone of children, adolescents, and young adults. Exceptionally, older patients are affected. The mean age is in the second to third decade. White males have the highest incidence and black females the lowest due to ethnic genetic preposition differences. Tumors can originate anywhere in the body, and around $80 \%$ of the neoplasms arise in the bone with preference sites in decreasing order of frequency: lower extremities, pelvis, upper extremities, ribs, spine, and craniofacial. Distribution in the soft tissue is extremities, chest wall, retroperitoneum, paravertebral, pelvis, and head and neck. Visceral organs, skin, and epidural spaces are rarely involved [12,13]. The origin of the peripheral nerve as reported by Stout in 1918 can clinically be confused with malignant peripheral nerve sheath tumor [7].

Macroscopically, these infiltrative lesions are (multi)nodular), fleshy, and often necrotic. A pseudocapsule can be present in soft tissue neoplasms. Post-therapy specimens show fibrosis, necrosis, and hemorrhage, often without visible tumor [12,13].

Histologically, Ewing sarcoma is composed of cellular sheets of relatively featureless small cells with round dark nuclei and inconspicuous cytoplasm (Figure 1). In some cases, cells are larger displaying more nuclear variability. The cytoplasm can appear clear due to retraction artefacts. Homer-Wright rosettes may be numerous in a subset of cases initially called peripheral primitive neuroectodermal tumors [6,13]. Adamantinoma-like Ewing sarcoma shows more cohesive sheets and nests of cells with peripheral palisading, prominent desmoplastic stroma with production of hyaline membrane collagen, presence of keratin pearl formation, and comedo-like necrosis. These lesions are predestinated for misinterpretation as carcinoma, since keratins, including high molecular keratins, p40, and p63, are commonly positive $[6,14]$.

Immunohistochemically, CD99 is specific in its distinct staining pattern of the cellmembrane. Nuclear FLI and ERG expression is commonly observed in the cases with corresponding fusion genes. Neuroendocrine markers may be expressed. Keratin-expression, often dot-like, was found in 1/3 of the cases; it can be confused with small-cell carcinoma, especially when combined with the expression of p40 and p63 [6,14]. This is of particular importance in the head and neck area [14]. Expression of NKX2-2 in Ewing sarcoma seems to be highly sensitive, with imperfect specificity in comparison to other small, blue round- 
cell tumors [15-19]. Expression of desmin is reported in a few cases, and can be confused with ARMS or desmoplastic small round-cell tumor (DSRCT) $[6,20]$.

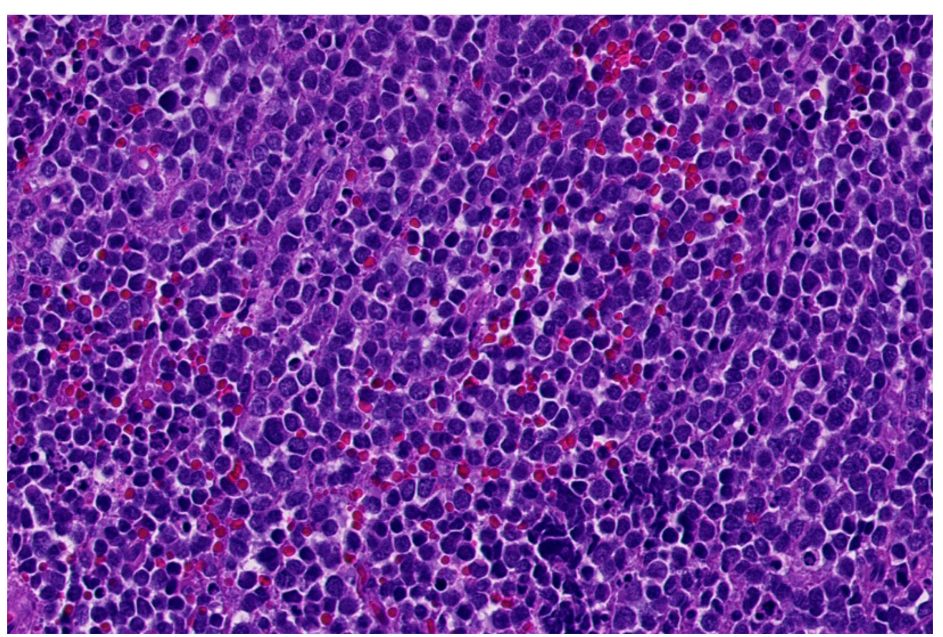

Figure 1. Classical morphology of Ewing sarcoma (HE; 40× magnification).

Ewing sarcoma is genetically characterized by binding of EWSR1 or other members of the TET/FET family to members of the ETS family [5]. Approximately $85-90 \%$ of the Ewing's sarcomas display the translocation $\mathrm{t}(11 ; 22)(\mathrm{q} 24 ; \mathrm{q} 12)$ resulting in the EWS/FLI1 fusion gene, and approximately $5-10 \%$ harbor a EWSR1-ERG fusion gene [6]. The remaining cases show rare gene partners, such as ETV1, ETV4, and FEV, and EWSR1 can be substituted by FUS [21].

Although prognosis has improved markedly for patients with primary disease (5-year survival rate around $65 \%$ ), presence of metastatic disease at time of diagnosis or early relapse leads to an adverse prognosis (5-year survival rate around $25-30 \%$ ), with adequate surgical resection, aggressive multimodal chemotherapy, and adjuvant local radiotherapy being the optimal treatments.

Differential diagnoses are listed in Table 1.

Table 1. Differential diagnoses of Ewing sarcoma.

\begin{tabular}{|c|c|c|c|}
\hline Entity & Morphology & IHC & Common Genetic Alterations \\
\hline CIC-sarcoma & $\begin{array}{l}\text { Sheets of undifferentiated } \\
\text { round/spindle/epitheloid cells; } \\
\text { mild nuclear pleomorphism; } \\
\text { and necrosis }\end{array}$ & $\begin{array}{l}\text { CD99 (mostly patchy), WT1, } \\
\text { ETV4, DUX4, and NUT } \\
\text { (CIC-NUTM1) }\end{array}$ & $\begin{array}{l}\text { CIC- } \\
\text { DUX4/FOXO4/LEUTX/NUTM1/2A } \\
\text { fusions }\end{array}$ \\
\hline BCOR-sarcoma & $\begin{array}{l}\text { Sheets/nests/short fascicles of } \\
\text { uniform; bland } \\
\text { round-oval-spindle cells; rich } \\
\text { capillary network; and myxoid } \\
\text { matrix (variable) }\end{array}$ & $\begin{array}{c}\text { BCOR, SATB2, cyclin D1, TLE1, } \\
\text { CCNB3 (BCOR-CCNB3), and } \\
\text { CD99 (50\%) }\end{array}$ & $\begin{array}{c}\text { BCOR-CCNB3/MAML3/ZC3H7B, } \\
\text { KMT2D); BCOR ITD*; and } \\
\text { YWHAE-NUTM2B; *ITD, internal } \\
\text { tandem duplication }\end{array}$ \\
\hline \multirow[b]{2}{*}{$\begin{array}{l}\text { EWSR1-nonETS } \\
\text { round-cell sarcomas }\end{array}$} & $\begin{array}{l}\text { Cords/nests/pseudoacinar } \\
\text { pattern of round-spindle cells; } \\
\text { bland-pleomorphic spectrum; and } \\
\text { fibro-/myxohyaline stroma }\end{array}$ & $\begin{array}{l}\text { CD99, NKX2.2, and CKAE1/3 } \\
\text { (focal, dot-like) }\end{array}$ & EWSR1/FUS-NFATc2 \\
\hline & $\begin{array}{l}\text { Diverse morphology: } \\
\text { round-spindle cells; } \\
\text { fibrous stroma }\end{array}$ & $\begin{array}{c}\text { Co-expression of } \\
\text { myogenic markers } \\
\text { (desmin/myogenin/MyoD1), } \\
\text { neurogenic markers } \\
\text { (S100/SOX10/MITF/GFAP) and } \\
\text { keratins (AE1/3) }\end{array}$ & EWSR1-PATZ1 or EWSR1-VEZF1 \\
\hline $\begin{array}{l}\text { Desmoplastic small } \\
\text { round-cell tumor }\end{array}$ & $\begin{array}{l}\text { Sheets/nests/cords of uniform; } \\
\text { bland round cells; and } \\
\text { desmoplastic stroma }\end{array}$ & $\begin{array}{c}\text { Desmin (dot-like), keratin, EMA, } \\
\text { and WT1 (C-terminus) }\end{array}$ & EWSR1-WT1 \\
\hline
\end{tabular}


Table 1. Cont.

\begin{tabular}{|c|c|c|c|}
\hline Entity & Morphology & IHC & Common Genetic Alterations \\
\hline Lymphoblastic lymphoma & $\begin{array}{l}\text { Small-medium blastoid cells; } \\
\text { minimal cytoplasm }\end{array}$ & $\begin{array}{l}\text { CD99, TdT, CD45, CD34, CD1a, } \\
\text { and B- and T-cel markers }\end{array}$ & Diverse \\
\hline Small-cell carcinoma & $\begin{array}{l}\text { Small-medium round-oval cells; } \\
\text { salt and pepper chromatin; } \\
\text { indistinct nucleoli; molding; } \\
\text { and apoptosis }\end{array}$ & $\begin{array}{l}\text { Keratins, } \\
\text { CD56, synaptophysin, } \\
\text { chromogranin, and TTF1 }\end{array}$ & $\begin{array}{c}\text { Diverse; TP53, PTEN mutations; } \\
\text { RB1, 3p loss; and MYC } \\
\text { amplification }\end{array}$ \\
\hline NUT carcinoma & $\begin{array}{l}\text { Poorly cohesive sheets of } \\
\text { primitive/basaloid cells; abrupt } \\
\text { keratinization; and } \\
\text { coagulative necrosis }\end{array}$ & CK5/6, P40, P63, and NUT & $\begin{array}{c}\text { NUT- } \\
\text { BRD3/BRD4/NSD3/CIC/BCORL1/ } \\
\text { MGA/MXD4 }\end{array}$ \\
\hline Myoepithelial carcinoma & $\begin{array}{l}\text { Solid sheets/nests of cell with } \\
\text { high nuclear grade or } \\
\text { undifferentiated round-cell } \\
\text { morphology; facultatively } \\
\text { glandular component; necrosis; } \\
\text { and high mitotic count }\end{array}$ & $\begin{array}{c}\text { Pankeratins, S100, EMA, GFAP, } \\
\text { SOX10, P63, SMA, calponin, } \\
\text { desmin (focal); and INI1 } \\
\text { loss (subset) }\end{array}$ & $\begin{array}{l}\text { EWSR1 rearrangements (various } \\
\text { fusion partners); PLAG1 } \\
\text { rearrangements (mixed tumors) }\end{array}$ \\
\hline ARMS & $\begin{array}{l}\text { Nests with central } \\
\text { discohesion-solid nests; } \\
\text { monomorphic primitive round } \\
\text { cells; and multinucleated } \\
\text { wreath-like giant cells }\end{array}$ & $\begin{array}{c}\text { Desmin, myogenin (strong, } \\
\text { diffuse), MyoD1, keratin, } \\
\text { neuro-endocrine markers (CD56, } \\
\text { synaptophysin, } \\
\text { and chromogranin) }\end{array}$ & PAX3/PAX7-FOXO1 \\
\hline Sinonasal glomangiopericytoma & $\begin{array}{l}\text { Solid-fascicular pattern; } \\
\text { spindle-round cells with minimal } \\
\text { atypia; arranged around staghorn } \\
\text { vessels; and } \\
\text { perivascular hyalinization }\end{array}$ & Beta-catenin (nuclear), SMA & CTNNB1 mutations \\
\hline Glomus tumor & $\begin{array}{l}\text { Solid-nested pattern; small, } \\
\text { uniform round cells with round } \\
\text { nucleus, amphophilic-slightly } \\
\text { eosinophilic cytoplasm and } \\
\text { sharply defined cell borders; and } \\
\text { variable vascular pattern }\end{array}$ & $\begin{array}{l}\text { SMA with membranous } \\
\text { accentuation, caldesmon, and } \\
\text { collagen IV }\end{array}$ & $\begin{array}{l}\text { MIR143-NOTCH1/2/3, and } \\
\text { BRAF/KRAS mutations }\end{array}$ \\
\hline Rhabdoid tumor & $\begin{array}{l}\text { Solid pattern; rounded-polygonal } \\
\text { cells with vesicular nuclei and } \\
\text { prominent nucleoli; and } \\
\text { eosinophil hyaline-like } \\
\text { cytoplasmic inclusions }\end{array}$ & $\begin{array}{c}\text { Diverse; keratins, EMA, CD99, } \\
\text { synaptophysin, SALL4, } \\
\text { glypican-3, and INI1 loss }\end{array}$ & $\begin{array}{l}\text { SMARCB1 biallelic loss, } \\
\text { SMARCB1 or SMARCA4 } \\
\text { (germline) mutations }\end{array}$ \\
\hline Mesenchymal chondrosarcoma & $\begin{array}{l}\text { Biphasic: poorly differentiated } \\
\text { round cells and islands of hyaline } \\
\text { cartilage; staghorn-like vessels }\end{array}$ & $\begin{array}{l}\text { S100, CD99, SOX9, EMA, desmin, } \\
\text { myogenin, and MyoD1 }\end{array}$ & HEY1-NCOA2 \\
\hline $\begin{array}{l}\text { Synovial sarcoma with } \\
\text { round-cell features }\end{array}$ & $\begin{array}{l}\text { Fascicles or sheets of small round } \\
\text { hyperchromatic cells; high N/C } \\
\text { ratio; staghorn vessels; necrosis; } \\
\text { and thin fibrovascular septa }\end{array}$ & $\begin{array}{l}\text { CD99, BCL2, CD56, TLE1, S100 } \\
\text { (focal), EMA, and keratins } \\
\text { (variable) }\end{array}$ & SS18-SSX1/2/4 \\
\hline
\end{tabular}

\section{Round-Cell Sarcomas with EWSR1-Non-ETS Fusions}

\subsection{NFATc2-Rearranged Sarcoma}

NFATc2-rearranged sarcoma was first described in 2009 by Szuhai et al. [22]. It is another, apparently very rare, primitive round-cell tumor with a methylation profile distinct from Ewing sarcoma, probably due to the non-ETS fusion gene [23]. Therefore, it belongs in the current WHO classification to the category of "round-cell sarcoma with EWSR1-non-ETS fusions" [5,24].

NFATc2-rearranged sarcoma affects males and females with predominance of males at least in the first studies. There is a broad age range from childhood to the elderly with a median age in the late third decade of life [24-26].

As Ewing sarcomas, these neoplasms originate mainly in the bone with predilection for the long bones, particularly femur and humerus. A few cases were reported to be localized in soft tissue and intraabdominally $[25,27]$. 
Histology demonstrates sheets, lobules, cords, and trabeculae of small, blue, round cells or less commonly spindle cells with slightly irregular nuclei. Nuclear pleomorphism is described in some lesions. There is a variable stromal reaction, being sclerotic, hyaline, myxoid, myxohyaline, and chondromyxoid. Cartilaginous or osteoid-like areas are rarely described [27].

Immunohistochemistry shows reaction for CD99; for AGGRECAN; and inconsistently for panCK AE, S100, BCOR, WT1, ERG, and ETV-4. Desmin, NKX3-1, and SATB2 are negative [27].

Amplification of the EWSR1-NFATC fusion gene is typical and can support the diagnosis when present $[22,23,25,27]$.

In a few cases, rearranged EWSR1 is substituted by FUS [26,27]. However, such cases show a different transcriptomic profile. While EWSR1-NFATC tumors were strongly enriched in genes associated with inflammatory response, the FUS-NFATC2 tumors showed a signature of proliferation and drug resistance [26].

The outcome of patients is uncertain, since response to chemotherapy in unclear. Histological response to multimodal therapy seen in the resection-specimens was poor [27]. Patient studies until now have been too small to draw definitive conclusions for prognosis. Favorable outcome is reported in few cases with long-term follow-up, mostly after complete resection. No data on radiotherapy effect are available [25].

Differential diagnoses are listed in Table 2.

Table 2. Differential diagnoses of EWSR1-non-ETS (NFATC2 and PATZ) fusions.

\begin{tabular}{|c|c|c|c|}
\hline Diagnosis & Morphology & IHC & Common Genetic Alterations \\
\hline Solitary fibrous tumor & $\begin{array}{l}\text { Patternless pattern of spindle cells } \\
\text { or round cells; hyalinized stroma; } \\
\text { collagen bundles; staghorn vessels; } \\
\text { and possibly fat component }\end{array}$ & CD34, BCL2, CD99, and STAT6 & NAB2-STAT6 \\
\hline Myoepithelial tumor & $\begin{array}{c}\text { Divers spectrum; } \\
\text { reticular/trabecular pattern; } \\
\text { variable spin- } \\
\text { dle/epithelioid/plasmocytoid/clear } \\
\text { cells; rarely ductal component } \\
\text { (mixed tumors); and } \\
\text { myxoid stroma }\end{array}$ & $\begin{array}{c}\text { Pankeratins, S100, SOX10, EMA, } \\
\text { GFAP, P63, SMA, calponin, and } \\
\text { desmin (focal) }\end{array}$ & $\begin{array}{l}\text { EWSR1 rearrangements (various } \\
\text { fusion partners); PLAG1 } \\
\text { rearrangements (mixed tumors) }\end{array}$ \\
\hline DSRCT & $\begin{array}{l}\text { Sheets/nests/cords of uniform, } \\
\text { bland, round cells; and } \\
\text { desmoplastic stroma }\end{array}$ & $\begin{array}{l}\text { Desmin (dot-like), keratin, EMA, } \\
\text { and WT1 (C-terminus) }\end{array}$ & EWSR1-WT1 \\
\hline CIC-sarcoma & $\begin{array}{l}\text { Sheets of undifferentiated } \\
\text { round/spindle/epitheloid cells; } \\
\text { mild nuclear pleomorphism; } \\
\text { and necrosis }\end{array}$ & $\begin{array}{l}\text { CD99 (mostly patchy), WT1, ETV4, } \\
\text { DUX4, and NUT (CIC-NUTM1) }\end{array}$ & $\begin{array}{c}\text { CIC- } \\
\text { DUX4/FOXO4/LEUTX/NUTM1/2A }\end{array}$ \\
\hline BCOR-sarcoma & $\begin{array}{l}\text { Sheets/nests/short fascicles of } \\
\text { uniform, bland round-oval-spindle } \\
\text { cells; rich capillary network; and } \\
\text { myxoid matrix (variable) }\end{array}$ & $\begin{array}{c}\text { BCOR, SATB2, cyclin D1, TLE1, } \\
\text { CCNB3 (BCOR-CCNB3), and CD99 } \\
(50 \%)\end{array}$ & $\begin{array}{c}\text { BCOR-CCNB3/MAML3/ZC3H7B, } \\
\text { KMT2D); BCOR ITD; and } \\
\text { YWHAE-NUTM2B }\end{array}$ \\
\hline ARMS & $\begin{array}{c}\text { Nests/sheets with central } \\
\text { discohesion (pseudoalveolar) or } \\
\text { solid nests; monomorphic, } \\
\text { primitive round cells; and } \\
\text { multinucleated wreath-like } \\
\text { giant cells }\end{array}$ & $\begin{array}{l}\text { Desmin, myogenin (strong, diffuse), } \\
\text { MyoD1, keratin, and } \\
\text { neuro-endocrine markers (CD56, } \\
\text { synaptophysin, chromogranin) }\end{array}$ & PAX3/PAX7-FOXO1 \\
\hline $\begin{array}{l}\text { Malignant peripheral nerve sheath } \\
\text { tumor/Triton }\end{array}$ & $\begin{array}{l}\text { Fascicles of spindle cells and/or } \\
\text { sheets epithelioid cells with } \\
\text { perivascular accentuation and } \\
\text { alternating cellularity; staghorn } \\
\text { vessels; geographic necrosis; and } \\
\text { heterologous differentiation } \\
\text { (rhabdomyoblasts, glandular } \\
\text { structures) }\end{array}$ & $\begin{array}{c}\text { S100, SOX10 (focally), and loss of } \\
\text { H3K27me3 }\end{array}$ & $\begin{array}{l}\text { Inactivating mutations of NF1, } \\
C D K N 2 A / B, E E D, \text { and } S U Z 2\end{array}$ \\
\hline Synovial sarcoma & $\begin{array}{l}\text { Sheets-fascicles; cellular, } \\
\text { monomorphic spindle cells; high } \\
\text { N/C ratio; variable epithelial } \\
\text { differentiation; staghorn vessels; } \\
\text { variable amount of collagen; mast } \\
\text { cells; and calcification/ossification; } \\
\text { poorly differentiated areas may } \\
\text { show round-epithelioid cells }\end{array}$ & $\begin{array}{l}\text { CD99, BCL2, CD56, TLE1, S100 } \\
\text { (focal), EMA, and keratins } \\
\text { (variable) }\end{array}$ & SS18-SSX1/2/4 \\
\hline
\end{tabular}




\subsection{EWSR1-PATZ and EWSR1-VEZF1 Rearranged Sarcoma}

EWSR1-PATZ-rearranged sarcomas were first reported by Mastrangelo et al. in 2000 [28]. Recently, more knowledge was gained based on advanced molecular technologies. EWSR1-PATZ-rearranged sarcoma seems to be a separate entity with a wide clinicopathological spectrum [26,29]. VEZF1 is considered a paralogue of PATZ, and the few cases described with EWSR1-VEZF1 are similar to the PATZ-rearranged cases in terms of morphology and immunoprofile [29-31].

The age ranges from early childhood to the elderly, with an average age in the fourth decade. The anatomic sites vary, with lesions being located superficially and deep, mainly in the trunk (thorax, including lung; abdomen), and rarely in the head and neck and extremities [29]. Intracranial localization is also reported [29,32].

Grossly, tumors are either well-circumscribed or infiltrating showing on the cut-surface a tan-yellow or grey-white color.

Histology is striking variable ranging from small blue round-cell morphology (Figures 2 and 3 ) to lesions showing a mixture of spindled, epithelioid, rhabdoid, ovoid, and round cells in varying fractions. The cells are commonly bland-looking with monomorphic nuclei and a low mitotic rate. They can be arranged in sheets, nests, and/or fascicles. Glandular structures as seen in synovial sarcoma, and pseudocystic spaces may be present. The stromal reaction is diverse and can be colleagenous, hyaline, or myxoid. There are often thick bands of collagen. Hyalinization of vessel walls are other possible features. Necrosis may occur but is mostly not prominent [29,33-35].

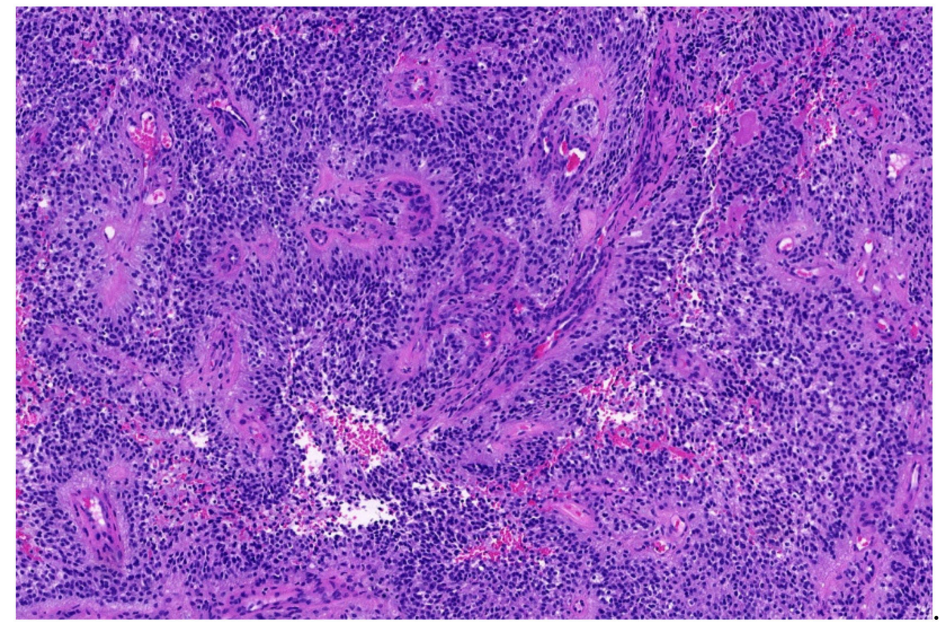

Figure 2. EWSR1-PATZ sarcoma with small blue round-cell morphology (HE; 20× magnification).

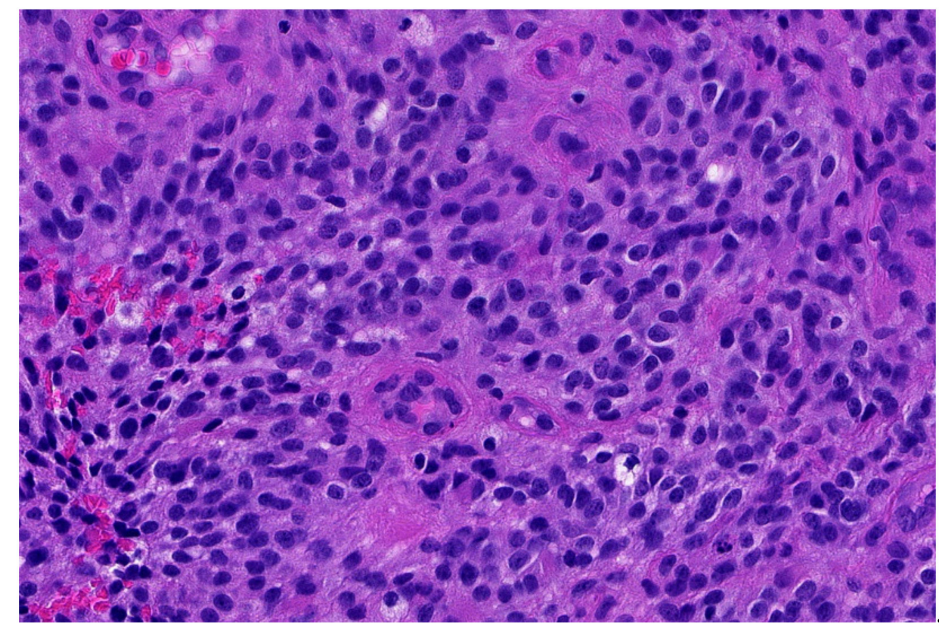

Figure 3. Higher magnification shows more irregular nuclei of the EWSR1-PATZ sarcoma in comparison to Ewing sarcoma (HE; $40 \times$ magnification). 
Michal et al. divided the tumors into two subgroups:

1. Low-grade appearing tumors: the spindled, epithelioid, ovoid, and round cells are set in a hyaline stroma reminiscent of solitary fibrous tumors and myoepithelioma.

2. Intermediate and high-grade appearing neoplasms have a round and/or ovoid morphology with few spindle cells and slight stromal component. The tumors of this second subgroup resemble other small, blue round-cell tumors, e.g., ARMS, BCOR-, and CIC-rearranged sarcoma.

Whether a transition may occur from low-grade to high-grade morphology as seen in myxoid/round-cell liposarcoma amongst others is yet unknown [29].

There is a polytypic immunophenotype with variable expression of neural, skeletal muscle, and epithelial markers. OLIG2 is also positive [29].

In contrast to NGS (or RT-PCR), FISH is not the method of choice for confirming the presence of the fusion gene due to the close proximity of the gene loci of PATZ and EWSR1 on chromosome 22q12 [29,34].

Based on whole transcriptome sequencing, EWSR1-PATZ rearranged sarcomas are different from other EWSR1-related sarcomas [26].

Lesions can be aggressive or follow a more favorable course [29,33-35]. It is unclear if the above-mentioned morphological grading is prognostic for outcome. In addition, deletions of $C D K N 2 A / B$ and $M D M 2$ gene amplification were associated with fatal outcome in one study and may therefore be a negative predictor of outcome [33].

\subsection{Small Blue Round-Cell Tumor with EWSR1-SMARCA5 Rearrangement}

A single case has been described in a 5-year-old female with a mass in the lumbosacral spinal canal with small blue round-cell histology and an immunoprofile like Ewing sarcoma. Cytogenetics showed a $\mathrm{t}(4 ; 22)(\mathrm{q} 31 ; \mathrm{q} 22)$ as sole abnormality resulting in an EWSR1-SMARCA5 fusion [36]. More cases are necessary for definitive categorization.

\subsection{Desmoplastic Small Round-Cell Tumor (DSCRT)}

The first description has been done by Gerald et al. in 1991, and one year later, the consistent translocation $\mathrm{t}(11 ; 22)(\mathrm{p} 13 ; \mathrm{q} 12)$ was found by Sawyer et al. [37-39]. Ladanyi et al. detected the corresponding fusion gene EWSR1-WT1 [40]. WT1, a suppressor of transcription, is expressed in primitive, developing mesothelium [41]. It is therefore not surprising that DSRCTs are classically located in the abdominal cavity with growth along the mesothelial membrane, often with multifocal spread at diagnosis. Origin in the small pelvis with ovary, or spermatic cord/paratesticular (tunica vaginalis), thoracic cavity/pleura, head and neck region, cranium/intracerebral, cauda equina, and extremities is rarely reported. Mostly adolescents and young adult males with a mean age in the second decade of life are affected, whereas females and older patients are rarely involved [21,38,41-43].

Grossly, this tumor is firm and shows a multinodular growth pattern with infiltration into adjacent structures and organs (e.g., liver). It has a solid and gray-white appearance with possible necrotic areas and hemorrhage [38,41].

Histologically, DSRCT is composed of irregular sheets, nests, trabecula, and cords of small cells with hyperchromatic nuclei and inconspicuous cytoplasm surrounded by a prominent desmoplastic stroma, which is a hallmark (Figure 4). When absent, other small round (or spindle) cell tumors could be superior in the differential diagnosis. Cells may vary in shape and size. The nuclei are round, ovoid, or spindly. In some cases, a rhabdoid/eosinophil or clear cytoplasm was noticed. The latter could be due to retraction during fixation process. Glandular/tubular or rosette-like structures have been identified in some cases. Mitotic figures may be numerous. Necrosis, possibly with calcification, can be present. The cells show immunohistochemically a polyphenotypic profile with expression of epithelial (EMA, broad-spectrum keratins (sometimes dot-like), myogenic (desmin, SMA in few cases), and neural markers (CD57, NSE) [21,38,41,43-45]. However, when this polyphenotype is incomplete, as sometimes seen, other small, blue round-cell 
tumors are conceivable, at least without the classical clinical context [46]. WT1 is only of diagnostic value when an antibody toward the carboxy terminus is used showing a nuclear staining pattern $[21,43,47]$. The presence of EWSR1-WT1 confirms the diagnosis in $>95 \%$ of the cases [41,43]. Multiple copies of the fusion gene have also been found [48].

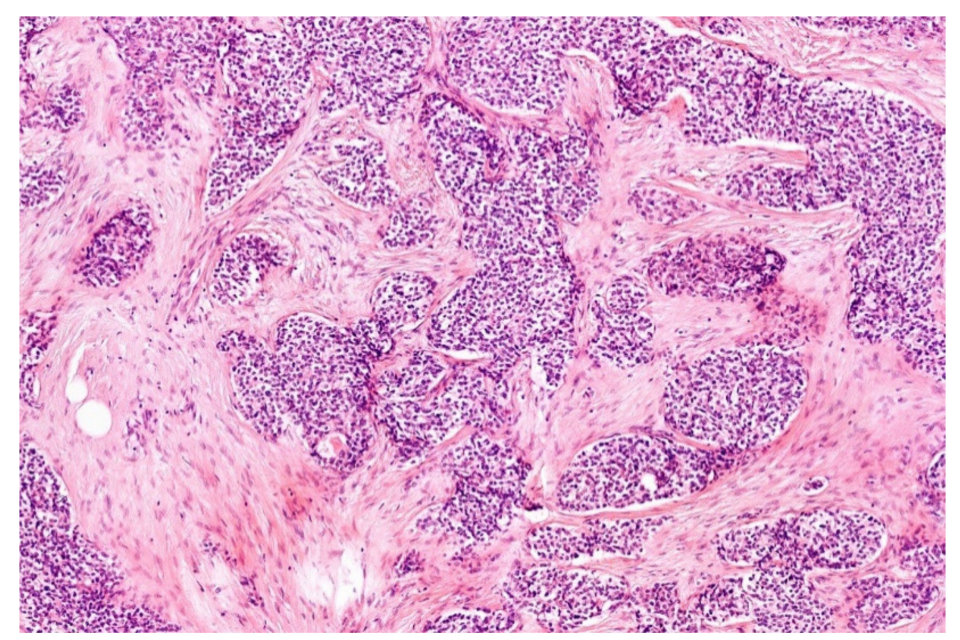

Figure 4. Small, blue, round cells situated in a desmoplastic stroma is characteristic for DSRCT (HE; $20 \times$ magnification).

The differential diagnoses besides other small blue round-cell sarcomas (Tables 1 and 2) can be carcinoids and small-cell carcinoma, including Merkel cell carcinoma because of the desmoplastic stroma reaction [38,41]. Neuroblastoma, lymphoma, and blastemic Wilms tumor are probably less relevant in the differential-diagnostic spectrum [41] (see Table 3).

Table 3. Differential diagnoses of DSRCT (except small blue round-cell sarcoma; see Ewing).

\begin{tabular}{|c|c|c|c|}
\hline Diagnosis & Morphology & IHC & $\begin{array}{c}\text { Common Genetic } \\
\text { Alterations }\end{array}$ \\
\hline Neuroblastoma & $\begin{array}{l}\text { Primitive cells; rosettes; } \\
\text { neuropil; and ganglion cells }\end{array}$ & $\begin{array}{l}\text { CD56, synaptophysin, and } \\
\text { chromogranin }\end{array}$ & $\begin{array}{l}\text { nMYC amplification; ATRK, } \\
\text { ALK mutations; and } \\
\text { chromosomal aberrations (1p, } \\
17 \mathrm{q} \text {, and } 11 \mathrm{q})\end{array}$ \\
\hline Lymphoma & $\begin{array}{c}\text { Variably sized } \\
\text { hyperchromatic-blastoid cells } \\
\text { with variable atypia; } \\
\text { minimal cytoplasm }\end{array}$ & CD45, B/T-cell markers & Diverse \\
\hline Blastemic Wilms & $\begin{array}{l}\text { Primitive, undifferentiated } \\
\text { round-to-spindled cells }\end{array}$ & WT1 (N-terminus), CD56 & $\begin{array}{l}\text { WT1, TP53 mutations; } \\
\text { 11p15.5 deletion }\end{array}$ \\
\hline $\begin{array}{l}\text { Small cell/neuroendocrine } \\
\text { carcinoma }\end{array}$ & $\begin{array}{l}\text { Small-medium round-oval } \\
\text { cells; salt and pepper } \\
\text { chromatin; indistinct nucleoli; } \\
\text { molding; and apoptosis }\end{array}$ & $\begin{array}{l}\text { Keratins } \\
\text { CD56, synaptophysin, } \\
\text { chromogranin, and TTF1 }\end{array}$ & $\begin{array}{c}\text { Diverse; TP53, PTEN } \\
\text { mutations; } R B 1,3 p \text { loss; and } \\
\text { MYC amplification }\end{array}$ \\
\hline $\begin{array}{l}\text { Metastatic Merkel } \\
\text { cell carcinoma }\end{array}$ & $\begin{array}{l}\text { Round-oval nuclei; high } \\
\text { N/C-ratio; salt and pepper } \\
\text { chromatin; indistinct nucleoli; } \\
\text { molding; and apoptosis }\end{array}$ & $\begin{array}{l}\text { Broad spectrum keratins; } \\
\text { CK20 (dot-like), CD56, } \\
\text { chromogranin, and } \\
\text { synaptophysin }\end{array}$ & $\begin{array}{c}\text { Diverse; depends on } \\
\text { polyomavirus (PyV) status; } \\
\text { PyV-tumors: } R b 1 \\
\text { TP53 mutations }\end{array}$ \\
\hline Small cell mesothelioma & $\begin{array}{c}\text { Solid nests; high N/C-ratio; } \\
\text { well defined membrane; fine } \\
\text { chromatin; and } \\
\text { indistinct nucleoli }\end{array}$ & $\begin{array}{l}\text { Calretinin, CK5/6, WT1 } \\
\text { (N-terminus), and D2-40 }\end{array}$ & $\begin{array}{c}\text { Diverse; } P 16 \text { loss; } B A P 1 \\
\text { mutation; NF2 deletion; and } \\
\text { ALK/EWSR1/FUS } \\
\text { rearrangments }\end{array}$ \\
\hline
\end{tabular}


Treatment is challenging, and survival is low despite initial response to multimodal chemotherapy. Debulking is usually the surgical procedure, and tumor-free margins can often not be achieved when extended surgery is performed. For local control, several different additions have been tried with varying effects, such as total abdominal irradiation or surgery in combination with HIPEC. However, most patients relapse with locally disseminated disease not responsive to further treatment. Distant metastases may occur with involvement of lungs, liver, lymph nodes, bone, kidney, pancreas, spleen, adrenal gland, and small pelvis [41,43,44,49]. An indolent clinical course is reported in some mainly unusual cases $[50,51]$.

\section{Myxoid Liposarcoma (MLS)}

MLS is the only translocation-associated liposarcoma-subtype recapitulating more or less normal lipogenesis with maturation arrest [5,52-54]. Limon et al. detected the most common translocation $(12 ; 16)$ in 1986 [55]. The specific fusion genes FUS-DDIT3 (ca 90\% of the cases) and, more rarely, EWSR1-DDIT3 (in up to $10 \%$ of cases) are the result of the $t(12 ; 16)(q 13 ; p 11)$ and $t(12 ; 22)(q 13 ; q 12)$, respectively [56,57]. DDIT is an enhancer binding family of transcription factor involved in erythropoiesis and adipogenesis [58,59].

MLS is the most common liposarcoma arising in children, adolescents, and young adults [60-63]. It comprises up to $35 \%$ of all liposarcomas and has, in $1 / 3$ of cases, the tendency to metastasize to other soft tissue sites, including mediastinum and retroperitoneum, and also to bone, lung, and liver, with a consecutive fatal outcome. The classical primary localization $(2 / 3$ of the cases) is the deep soft tissues commonly of the thigh $[60,64]$. Cases of the retroperitoneum are almost exclusively metastases, with some exceptions $[65,66]$. At distal sites of the extremities, this tumor is exceedingly rare [54].

Macroscopically, the lesion is multinodular and gelatinous on cut surface. High grade areas are firm and grey-white in appearance.

Histology depicts a nodular growth pattern of relatively low cellularity with enhancement of cells at the periphery of the nodules. There is a proliferation of uniform bland, round-to-oval-shaped primitive cells intermingled with a variable amount of lipoblasts of different stages in an abundant myxoid stroma. Slightly pleomorphic nuclei are often associated with multivacuolated cytoplasm (Figure 5). In addition to the classical features, a nested pattern or islands of primitive cells, areas of extensive maturation, pseudoacini, or a cord-like growth pattern can be obvious. The very characteristic delicate plexiform ('chicken-wire') capillary vasculature is less obvious in cellular areas. When present, hemangiopericytoma-like vessels can be confused with solitary fibrous tumor, especially the lipomatous variant. Stromal hyalinization is rarely reported, which can be misleading if prominent. Hypercellular morphology with more large round cells with increased nuclear/cytoplasmic ratio, distinct nucleoli, and a small amount of intervening myxoid stroma is called round-cell liposarcoma and is associated with an inferior prognosis when more than $5 \%$ of the neoplasm is affected [5].

Immunohistochemistry shows variable expression of S100, which is of little value $[21,54,62]$. The determination of the fusion gene is therefore an important confirmation that has consequences therapeutically. Recently, nuclear expression of DDIT3 as an appropriate immunohistochemical surrogate marker has been reported [67-69].

In the differential diagnosis is lipoblastoma, which rarely occurs in adults, at least in its primitive form, and myxoid pleomorphic liposarcoma when slight pleomorphism is present. Chondroid lipoma can be considered because of lipoblastic differentiation, and soft tissue angiofibroma shows some similarities in terms of the branching capillaries, which do not have such a delicate appearance in the latter. Small, blue round-cell tumors can be pondered when round-cell morphology without obvious lipoblasts is observed [54] (see Tables 1, 2 and 4). 


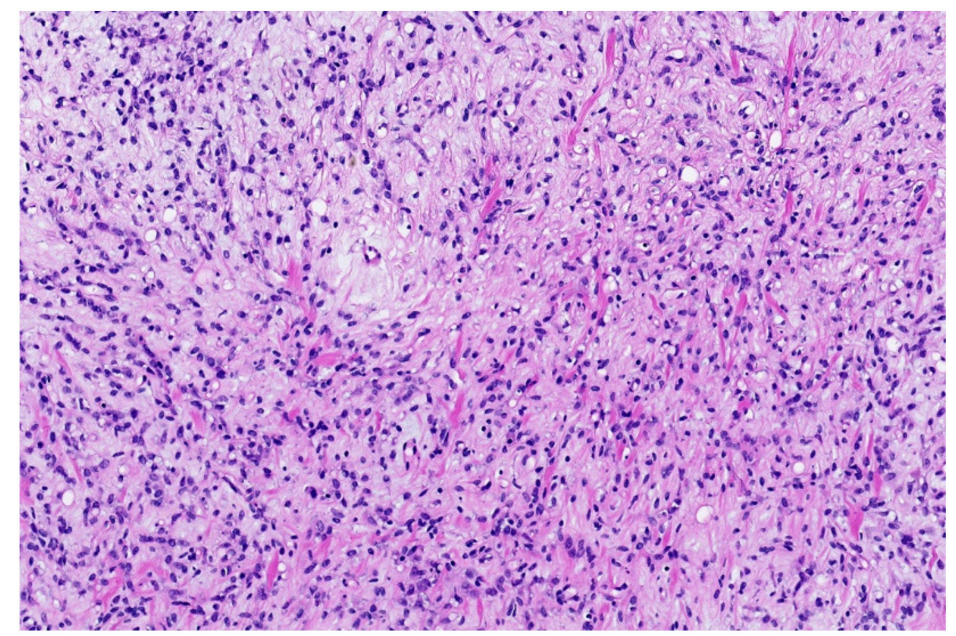

Figure 5. Myxoid liposarcoma showing different stages of primitive fat cells. There is slight pleomorphism. The myxoid matrix contains variable collagen (HE; 20× magnification).

Table 4. Differential diagnoses of MLS.

\begin{tabular}{|c|c|c|c|}
\hline Diagnosis & Morphology & IHC & $\begin{array}{l}\text { Common Genetic } \\
\text { Alterations }\end{array}$ \\
\hline Lipoblastoma & $\begin{array}{l}\text { Lobulated architecture with } \\
\text { fibrous septa with often } \\
\text { prominent vasculature; } \\
\text { possibly myxoid stroma with } \\
\text { possibly plexiform } \\
\text { vasculature; resembling fetal } \\
\text { fat with prelipoblasts, } \\
\text { lipoblasts, and mature fat in } \\
\text { variable portions }\end{array}$ & Not specific & $\begin{array}{l}\text { PLAG1 rearrangements } \\
\text { (various fusion partners) }\end{array}$ \\
\hline $\begin{array}{l}\text { Myxoid pleomorphic } \\
\text { liposarcoma }\end{array}$ & $\begin{array}{l}\text { Progressive transition } \\
\text { between areas resembling } \\
\text { myxoid liposarcoma and } \\
\text { pleomorphic liposarcoma; } \\
\text { pleomorphic cells; and } \\
\text { myxoid matrix }\end{array}$ & Not specific & RB1 deletion, TP53 mutations \\
\hline Chondroid lipoma & $\begin{array}{l}\text { Myxohyaline chondroid } \\
\text { matrix; lipoblasts } \\
\text { intermingled with mature } \\
\text { adipocytes and chondroid } \\
\text { cells; and vascularized septa }\end{array}$ & $\begin{array}{l}\text { S100 (mature adipocytes and } \\
\text { lipoblasts); keratins (rare) }\end{array}$ & C110r95-MRTFB \\
\hline Soft tissue angiofibroma & $\begin{array}{l}\text { Myxoid-collagenous stroma; } \\
\text { prominent, branching } \\
\text { vasculature; and bland } \\
\text { spindle cells, } \\
\text { possibly adipocytes }\end{array}$ & $\begin{array}{l}\text { CD34, EMA, desmine } \\
\text { (dendritic cells) }\end{array}$ & $\begin{array}{l}\text { NCOA2 rearrangements } \\
\text { (various fusion partners) }\end{array}$ \\
\hline $\begin{array}{l}\text { Small, blue round-cell tumors } \\
\text { (when round-cell } \\
\text { liposarcoma) }\end{array}$ & $\begin{array}{c}\text { Cells with small } \\
\text { round-oval-spindle cells with } \\
\text { little cytoplasm }\end{array}$ & $\begin{array}{l}\text { See Table Ewing and } \\
\text { Ewing-like sarcomas }\end{array}$ & $\begin{array}{l}\text { See Table Ewing and } \\
\text { Ewing-like sarcomas }\end{array}$ \\
\hline
\end{tabular}

Neo-adjuvant radiotherapy leading to a good response with maturation and hyalinization, followed by resection, is the optimal treatment [70]. Recurrences are less frequent. When metastasized (up to $1 / 3$ of the patients), the outcome is poor; however, a slow progression may be observed. 


\section{Tumors with EWSR1/FUS Fused to the CREB-Family}

ATF1, CREB1, and CREM are members of the CREB-family of transcription factors playing a pivotal role in diverse physiological processes [71,72]. They act as fusion partners of EWSR1 or alternating FUS in several benign, intermediate, and fully malignant tumors, and the growing list includes mesenchymal, neuroectodermal, and epithelial neoplasms. Secondary genetic and/or epigenetic events seem to be mandatory for the specific oncogenesis. Whereas EWSR1-ATF1 and EWSR1-CREB are the two most characterized fusions, EWSR1-CREM is less well studied [72]. Whether or not AFH (including its myxoid variant), PPMS, so-called mesothelioma, and EWSR1-CREM undifferentiated sarcoma are a spectrum of one tumor type will yield further studies in the future.

\subsection{Angiomatoid Fibrous Histiocytoma (AFH)}

This lesion was firstly recognized by Enzinger in 1979 with the main characteristics being reported in his seminal paper [73]. In 2000, the first genetic report was published showing FUS-ATF1 as the result of $\mathrm{t}(12 ; 16)$ (q13;p11) [74]. Later on, it became apparent that EWSR1/FUS-CREB/ATF1/CREM are the alternating candidates for the gene fusion, with EWSR1-CREB1 being the most common in soft tissue lesions $[21,75,76]$. EWSR1-CREM positive cases are recently reported [72]. Multiple copy numbers of the fusion gene seem to be associated with pleomorphism [76].

AFH affect mainly children, adolescents, and young adults. However, the age range is broad. When located in superficial soft tissue, clinical presentation is often a palpable, slowly growing indolent nodus imposing as hemangioma or lymph node $[21,73,77,78]$. Rarely accompanied systemic symptoms such as malaise, pyrexia, and anemia are documented [21,78-80]. Classically, AFH arises subcutaneously in the extremities followed by the trunk and head and neck $[21,73,77]$. Involvement of deep soft tissues and visceral sites is increasingly reported due to higher diagnostic standards (including molecular diagnostics). They include mediastinum, retroperitoneum, intraabdominal, lung, brain, bone, and ovary [78,80-83].

Grossly, the neoplasm is circumscribed, (multi)nodular or (multi)cystic, grayishyellow, and hemorrhagic, and can be as large as $10 \mathrm{~cm}[73,80]$.

Histologically, these circumscribed (multi)nodular and/or multicystic lesions possess a fibrous pseudocapsule that is surrounded by a prominent often lymph node-like mixed lymphocytic infiltrate with variable germinal center formation and presence of plasma cells. The inflammatory component may also be intermixed with tumor. The tumor cells are arranged in sheets, nodules/whorls, aggregates, short fascicles (storiform), and reticular formations (when myxoid). The cells are histiocytoid with a syncytial aspect showing an ovoid, epithelioid, or spindled appearance and bland-looking nuclei with fine chromatin and moderate amount of ill-defined eosinophilic cytoplasm (Figure 6). Centrally, a cannonball arrangement can be seen. Unusual characteristics are scattered large cells, nuclear grooving, and bizarre and irregularly folded nuclei. Rhabdoid, clear cells, or osteoclast-like giant cells and Ewing-like areas may be present. Nuclear palisading as seen in schwannomas has been rarely observed. Mitotic rate is usually low, but atypical mitoses are not a worrisome sign. Hemorrhage and blood-filled spaces are, when present, a hallmark of this lesion often associated with hemosiderin deposition [21,73,77-82,84]. The stroma can be unremarkable, sclerotic, "desmoplastic", or myxoid. Edema can be prominent, and a slit-like pseudovascular pattern may be seen. Additionally, perivascular hyalinization is a possible sign $[80,82,84]$.

Immunohistochemistry shows expression of ALK in almost all cases and desmin in approximately 50\% of the cases. EMA, CD99, and CD68 are variably expressed. Other smooth muscle markers such as SMA and caldesmon are sometimes positive. CD21 may be positive in some cells. Myogenin and MYOD1 are consistently absent [21,77,79,80].

Intracranial myxoid mesenchymal tumors are suggested to be a variant of AFH $[83,85]$. This meets the observations of peripherally located AFHs with myxoid changes $[72,84,86]$. Differential diagnoses are listed in Table 5. 


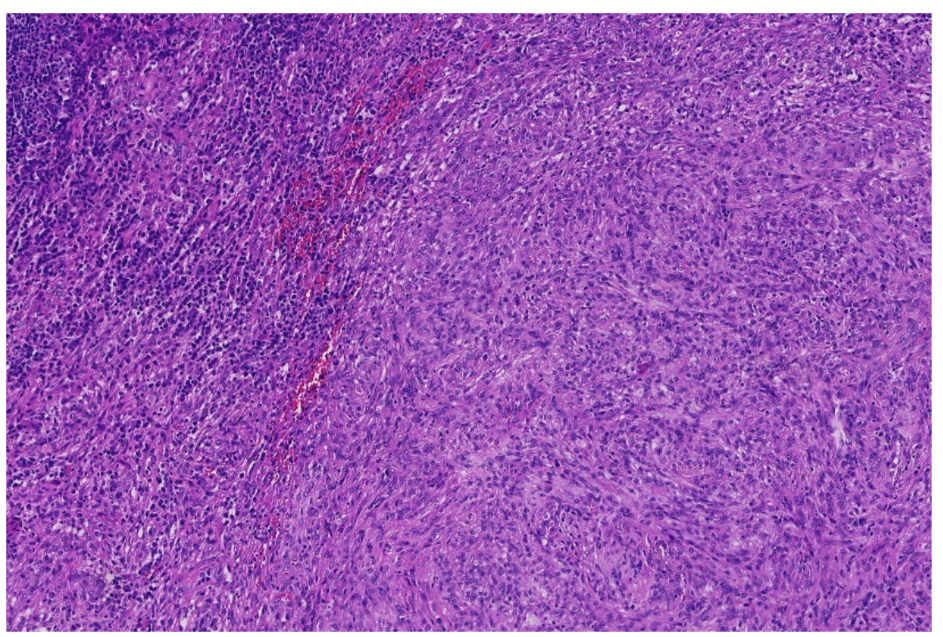

Figure 6. Angiomatoid fibrous histiocytoma showing sheets and short fascicles of histiocytoid cells with monomorphic nuclei. Note the lymphocytic reaction (HE; $20 \times$ magnification).

Table 5. Differential diagnoses of AFH.

\begin{tabular}{|c|c|c|c|}
\hline Diagnosis & Morphology & IHC & $\begin{array}{l}\text { Common Genetic } \\
\text { Alterations }\end{array}$ \\
\hline Histiocytic lesions & $\begin{array}{l}\text { Diverse; histiocytes; and } \\
\text { multinucleated giant cells }\end{array}$ & $\begin{array}{l}\text { Diverse (depending on entity); } \\
\text { CD68, CD163, and FXIIIA }\end{array}$ & $\begin{array}{c}\text { Diverse (depending on entity); } \\
\text { activating MAPK signaling } \\
\text { mutations (BRAF, NRAS, } \\
K R A S, A R A F \text {, and } M A P 2 K 1)\end{array}$ \\
\hline Follicular dentritic sarcoma & $\begin{array}{l}\text { Fascicles/whorls/storiform } \\
\text { pattern; oval-spindle cells } \\
\text { with small nucleoli and } \\
\text { syncytial borders; nuclear } \\
\text { pseudoinclusions; binucleate } \\
\text { (often) or multinucleate (rare) } \\
\text { forms; and admixed } \\
\text { lymphocytic infiltrate with } \\
\text { perivascular } \\
\text { lymphocytic cuffs }\end{array}$ & CD21, CD23, CD35, and D2-40 & $\begin{array}{l}\text { Highly diverse } \\
\text { mutational profile }\end{array}$ \\
\hline $\begin{array}{l}\text { Small, blue round-cell tumors } \\
\text { See Tables } 1 \text { and } 2\end{array}$ & $\begin{array}{l}\text { Cells with small } \\
\text { round-oval-spindle cells with } \\
\text { scant cytoplasm }\end{array}$ & Diverse (depending on entity) & Diverse (depending on entity) \\
\hline $\begin{array}{l}\text { Epithelioid fibrous } \\
\text { histiocytoma }\end{array}$ & $\begin{array}{l}\text { Polypoid; epidermal collarette; } \\
\text { epithelioid cells with vesicular } \\
\text { nuclei, small nucleoli, and } \\
\text { amphophilic cytoplasm }\end{array}$ & FXIIIA, EMA, and ALK & $\begin{array}{l}A L K \text { rearrangements (various } \\
\text { fusion partners) }\end{array}$ \\
\hline $\begin{array}{l}\text { Aneurysmatic fibrous } \\
\text { histiocytoma }\end{array}$ & $\begin{array}{l}\text { Epidermal hyperplasia and } \\
\text { basal layer pigmentation; } \\
\text { circumscribed, dermal based } \\
\text { proliferation; haphazard } \\
\text { arrangement of ovoid spindle } \\
\text { cells; admixed foam and giant } \\
\text { cell; central blood-filled cystic } \\
\text { space; and abundant } \\
\text { hemosiderin deposition }\end{array}$ & FXIIIA, SMA & Not specific \\
\hline Rhabdomyosarcoma & $\begin{array}{l}\text { Monomorphic primitive } \\
\text { round cells with variable } \\
\text { rhabdomyoblastic } \\
\text { differentiation (depending } \\
\text { on subtype) }\end{array}$ & $\begin{array}{l}\text { Desmin, myogenin, } \\
\text { and MyoD1 }\end{array}$ & $\begin{array}{c}\text { Diverse (depending on } \\
\text { subtype); PAX3/PAX7-FOXO1 } \\
\text { fusions (ARMS); alterations of } \\
\text { RAS signaling pathway } \\
\text { (embryonal RMS) }\end{array}$ \\
\hline
\end{tabular}


Table 5. Cont.

\begin{tabular}{|c|c|c|c|}
\hline Diagnosis & Morphology & IHC & $\begin{array}{l}\text { Common Genetic } \\
\text { Alterations }\end{array}$ \\
\hline Rhabdoid tumor & $\begin{array}{c}\text { Solid pattern; } \\
\text { rounded-polygonal cells with } \\
\text { vesicular nuclei and } \\
\text { prominent nucleoli; and } \\
\text { eosinophil hyaline-like } \\
\text { cytoplasmic inclusions }\end{array}$ & $\begin{array}{c}\text { Diverse; keratins, EMA, CD99, } \\
\text { synaptophysin, SALL4, } \\
\text { glypican-3, and INI1 loss }\end{array}$ & $S M A R C B 1$ biallelic loss \\
\hline $\begin{array}{c}\text { Inflammatory myofibroblastic } \\
\text { tumor }\end{array}$ & $\begin{array}{l}\text { Fascicular pattern (variable); } \\
\text { plump-spindle cells with } \\
\text { vesicular nuclei and small } \\
\text { nucleoli; amphophilic } \\
\text { cytoplasm; } \\
\text { oedematous-myxoid-fibrous } \\
\text { stroma; and mixed } \\
\text { inflammatory infiltrate }\end{array}$ & $\begin{array}{l}\text { SMA, calponin, desmin, } \\
\text { keratin (focal), ALK, and } \\
\text { ROS1 }\end{array}$ & $\begin{array}{c}A L K \text { rearrangements (various } \\
\text { fusion partners); ROS1, } \\
\text { NTRK3, RET, or PDGFRB } \\
\text { rearrangements }\end{array}$ \\
\hline Carcinoma & $\begin{array}{l}\text { Sheets/nests/trabecula; } \\
\text { round-oval-epithelioid cells } \\
\text { with nuclear atypia and } \\
\text { variable amount of cytoplasm }\end{array}$ & $\begin{array}{l}\text { Pankeratins, lineage specific } \\
\text { markers (depending on site of } \\
\text { origine) }\end{array}$ & $\begin{array}{l}\text { Diverse (depending on site of } \\
\text { origin) }\end{array}$ \\
\hline Meningeoma & $\begin{array}{l}\text { Highly diverse (according to } \\
\text { subtype and grade): lobulated; } \\
\text { whorled, fascicular pattern; } \\
\text { spindle or plump syncytial } \\
\text { cells; intranuclear } \\
\text { pseudoinclusions; and } \\
\text { psammoma bodies }\end{array}$ & EMA, S100, and PR & Monosomy 22; NF2 deletions \\
\hline $\begin{array}{l}\text { Extraskeletal myxoid } \\
\text { chondrosarcoma }\end{array}$ & $\begin{array}{l}\text { Multinodular; } \\
\text { lace-like/reticular pattern; } \\
\text { round-spindle monomorphic } \\
\text { cells; eosinophilic cytoplasm; } \\
\text { and myxoid matrix }\end{array}$ & Non-specific; S100 (focal) & $\begin{array}{l}\text { NR4A3-EWSR1- } \\
\text { /TAF15/TCF12/TFG }\end{array}$ \\
\hline Myoepithelioma (syncytial) & $\begin{array}{l}\text { Cutaneous; poorly } \\
\text { marginated; syncytial growth; } \\
\text { sheets of uniform } \\
\text { ovoid-histiocytoid-epithelioid } \\
\text { cells; and minimal stroma }\end{array}$ & $\begin{array}{l}\text { S100, EMA, GFAP, SMA, } \\
\text { and calponin }\end{array}$ & EWSR1-PBX3 \\
\hline Myxoid liposarcoma & $\begin{array}{l}\text { Lobulated; primitive uniform } \\
\text { round-ovoid cells; variable } \\
\text { number of lipoblasts; myxoid } \\
\text { stroma; and plexiform } \\
\text { vasculature (chicken wire) }\end{array}$ & DDIT3 & FUS/EWSR1-DDIT3 \\
\hline
\end{tabular}

AFH has a low to intermediate biologic potential, with most cases behaving benign. Recurrence is reported in up to $15 \%$ of the cases, especially when marginally excised. Metastases have been reported in up to $5 \%$, most frequently in the regional lymph nodes and exceptionally in the lungs, liver, and brain. Pleomorphism and increased mitotic activity are not associated with worse outcome [21,77,82].

\subsection{Primary Pulmonary Myxoid Sarcoma (PPMS)}

PPMS, an entity rendered by Thway et al. in 2011, is an EWSR1-CREB1 fusion gene associated neoplasm of the lung. It predominantly arises intrabronchially and involves the pulmonary parenchyma. It affects young to middle-aged adults, mainly women [21,87].

Morphologically, lesions are (multi)nodular with a pale and glistening cut surface on macroscopy. Microscopically, round-to-ovoid or spindle cells are situated in a myxoid 
matrix arranged in cords with possible reticular growth, as seen in extraskeletal myxoid chondrosarcoma (see there), nests, and sheets. Cells are relatively bland looking with at most slight nuclear pleomorphism (Figure 7). There is a low mitotic index and possibly focal necrosis. An inflammatory component is often obvious with presence of lymph follicles, either marginal or intralesional. Immunohistochemistry is of little value, with a faint reaction for EMA, but helps to exclude other lesions [21,87].

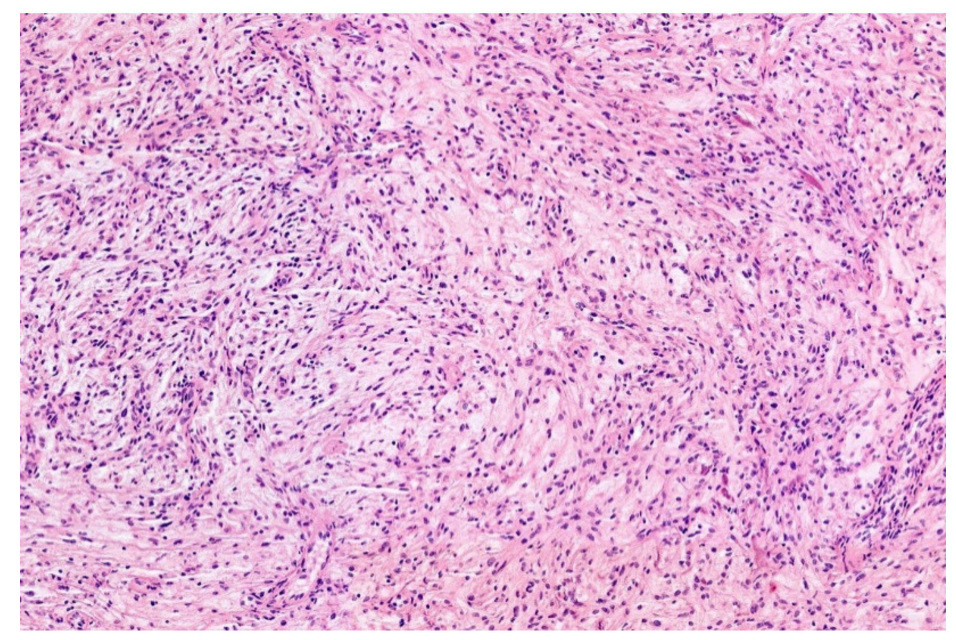

Figure 7. Primary pulmonary myxoid sarcoma: relatively uniform spindle cells arranged in loose fascicles in a myxoid matrix (HE; $20 \times$ magnification).

Lesions may be benign or malignant (with described metastases in kidney and brain) [21,87].

To what extent AFH and PPMS are related needs to be further explored. A close relationship is conceivable. Differential diagnoses are listed in Table 6.

Table 6. Differential diagnoses of PPMS.

\begin{tabular}{cccc}
\hline Diagnosis & Morphology & IHC & Common Genetic Alterations \\
\hline $\begin{array}{c}\text { Salivary gland } \\
\text { myoepithelial tumors }\end{array}$ & $\begin{array}{c}\text { Strands/nests/ductular } \\
\text { structures of } \\
\text { epithelial/myoepithelial cells; and } \\
\text { chondromyxoid/hyalinised } \\
\text { stroma }\end{array}$ & $\begin{array}{c}\text { Epithelial cells: EMA, } \\
\text { cytokeratins; Myoepithelial cells: } \\
\text { GFAP, S100, SOX10, p40, p63, } \\
\text { and SMA }\end{array}$ & PLAG1 or HMGA2 fusions \\
Angiomatoid fibrous histiocytoma & $\begin{array}{c}\text { Syncytial/whorling pattern } \\
\text { (classic AFH); reticular/lace-like } \\
\text { pattern (myxoid AFH); uniform } \\
\text { histiocytoid cells; blood-filled } \\
\text { pseudocysts; and } \\
\text { inflammatory/lymphocytic } \\
\text { reaction (lymph node-like) }\end{array}$ & Desmin, EMA, and ALK & EWSR1-ATF1 or EWSR1-CREB1 \\
\hline $\begin{array}{c}\text { Multinodular; lace-like/reticular } \\
\text { pattern; round-spindle } \\
\text { monomorphic cells with } \\
\text { chtraskeletal myxoid }\end{array}$ & eosinophilic cytoplasm; and \\
myxoid stroma & Non-specific; S100 (focal) & \\
\hline
\end{tabular}

\subsection{EWSR1-CREM Undifferentiated Sarcoma}

Currently, these tumors are still relatively unexplored.

One aggressive intraabdominal tumor in an adolescent was described consisting of swirls of uniform spindle cells with intercellular delicate collagen. Immunohistochemistry shows expression of vimentin, cytokeratin AE1/3, and CD56. EMA, CD34, ALK, synaptophysin, and DOG1 were focally positive. INI1 and H3K27me3 were retained. Negative were desmin, myogenin, S100, SOX10, NUT, CD31, and smooth muscle markers [72]. 
The other tumor was that of a 63-year-old woman with localization in the chest wall and a sclerosing epitheloid fibrosarcoma-like morphology with MUC4 and synaptophysin expression. The stroma was more fibrillary than sclerotic. After 17 months, there was no evidence of disease [72]. A comparable case was included in the study by Arbajian et al. 2017 [88,89]. Sequencing techniques should be applied in the right context to detect this rearrangement.

\subsection{Clear-Cell Sarcoma (CCS)}

Enzinger was the first to describe CCSs systematically in 1965 [90] (Enzinger 1965), also called melanoma of soft parts, because of overlapping morphological and immunohistochemical features with melanoma [91]. In the years 1990, 1991, and 1992, the translocation $(12 ; 22)(\mathrm{q} 13 ; \mathrm{q} 12)$ was found [92-94], one year after the EWSR1-ATF1 gene fusion by Zucman et al. 1993 [95]. Later on, it became apparent that CREB1 and CREM are substituents of ATF1 involving a smaller subset of cases [72,96,97].

Young adults (30-40 years) with equal sex distribution are the main group of patients. However, there is a broad age range from children to the elderly [90-92,97-102]. Additionally, there is a race distribution with the overwhelming majority of patients being Caucasian, whereas black people and Asians are uncommonly afflicted [101].

The deep soft tissue of the extremities is for the most part involved. Superficial soft tissue and skin localization does not exclude diagnosis. Extension into bone can be seen. Unusual tumor sites include the trunk, e.g., breast, anus, mediastinum, pleura, retroperitoneum, and the head and neck area. Symptoms depend on site and are nonspecific. Tumors can be large (up to $15 \mathrm{~cm}$ ) [90-92,97,98,101-104].

Grossly, tumors are firm and roughly spherical, with a smooth, nodular, or coarsely lobular surface. Most are well defined and surrounded by a fibrous pseudocapsule. Illdefined lesions are less frequently reported. The cut surface is usually gray to white. Brown areas and gelatinous foci are observed [90,102].

Microscopically, the classical pattern is that of a well delineated tumor with extension into adjacent structures consisting of nests or short fascicles of monomorphic round-to spindled cells with ample clear to eosinophilic cytoplasm, vesicular nuclei, and prominent nucleoli (Figure 8). Mitotic activity is variable but rarely brisk. Cells are separated by delicate fibrous septa. Typical are multinucleated giant cells with wreath-shaped nuclei. A diffuse growth pattern and pleomorphism are seen in some instances. Also reported are rhabdoid cells, an alveolar growth pattern, a seminoma-like appearance with a lymphocyterich fibrovascular stroma, and a dominant stromal reaction. Melanin pigment may be present, and necrosis can be found [90-92,97-99,102,104].

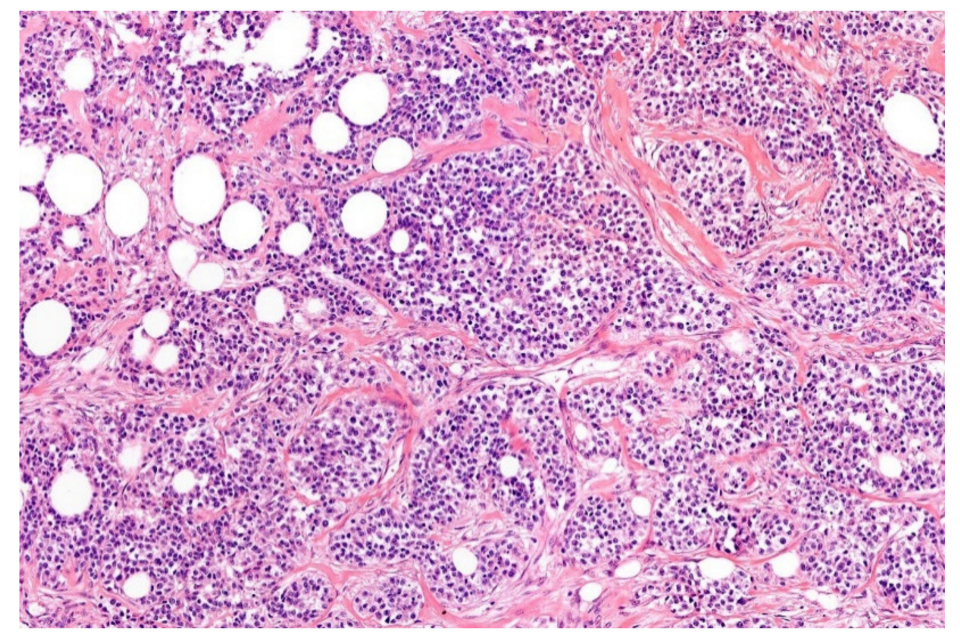

Figure 8. Clear-cell sarcoma comprises of nests of epithelioid cells separated by fibrous septa. There are uniform round nuclei and eosinophilic to clear cytoplasm (HE; 20× magnification). 
Melanoma markers are expressed using immunohistochemistry [97-99,104].

Melanoma is the most important differential diagnosis. It has to be discriminate from CCS because of the therapeutic consequences [105]. Other differential diagnoses are listed in Table 7.

Table 7. Differential diagnoses of CCS.

\begin{tabular}{|c|c|c|c|}
\hline Diagnosis & Morphology & IHC & $\begin{array}{l}\text { Common Genetic } \\
\text { Alterations }\end{array}$ \\
\hline Melanoma & $\begin{array}{l}\text { Diverse growth patterns; } \\
\text { large, atypical } \\
\text { spindle-epithelioid-bizarre cells } \\
\text { with vesicular nuclei and } \\
\text { prominent, eosinophilic nucleoli; } \\
\text { nuclear pseudo-inclusions; } \\
\text { abundant eosinophilic-clear } \\
\text { cytoplasm; and melanin pigment }\end{array}$ & $\begin{array}{l}\text { S100, SOX10, Melan-A, } \\
\text { HMB45, and MITF }\end{array}$ & $\begin{array}{c}\text { Diverse: ARID2, BAP1, BRAF, } \\
\text { GNAQ, HRAS, KIT, NF1, } \\
\text { NRAS, PTEN mutations; and } \\
\text { chromosomal gains/losses }\end{array}$ \\
\hline Epithelioid Schwannoma & $\begin{array}{l}\text { Multilobulated growth; } \\
\text { encapsulated; nests or single cells; } \\
\text { variableschwannoma } \\
\text { epithelioid cells; and } \\
\text { myxoid-hyalinized stroma }\end{array}$ & $\begin{array}{l}\text { S100, SOX10, Loss of } \\
\text { INI1 }(\sim 40 \%)\end{array}$ & Loss of SMARCB1 ( 40\%) \\
\hline Myoepithelial tumors & $\begin{array}{c}\text { Divers spectrum; } \\
\text { reticular/trabecular } \\
\text { pattern; variable } \\
\text { spindle/epithelioid/clear/ } \\
\text { plasmocytoid/rhabdoid cells; } \\
\text { rarely ductal component (mixed } \\
\text { tumors); fibromyxoid stroma; and } \\
\text { hyalinization }\end{array}$ & $\begin{array}{c}\text { Pankeratins, S100, SOX10, } \\
\text { EMA, GFAP, P63, SMA, } \\
\text { calponin, and desmin (focal) }\end{array}$ & $\begin{array}{l}\text { EWSR1 rearrangements } \\
\text { (various fusion partners); } \\
\text { PLAG1 rearrangements } \\
\text { (mixed tumors) }\end{array}$ \\
\hline
\end{tabular}

Excision is the treatment of choice. In a large epidemiological study, radiotherapy and chemotherapy were applied in $34 \%$ and $20 \%$, respectively [101]. Whether this confers any survival advantage is unclear. At least some tumors are reported to be chemosensitive [99]. Local recurrences and in-transit metastases are reported in around 20\% of the cases [99]. Sites of metastases are the lung (most commonly) and lymph nodes. The propensity to metastasize to lymph nodes is typical in comparison to most other sarcoma types. Overall, estimated 5- and 10-year survival is approximately $50 \%$ and $38 \%$, respectively $[98,99,101,102]$.

\subsection{Clear-Cell Sarcoma-Like Tumor of the Gastrointestinal Tract (Osteoclastrich Tumor of the Gastrointestinal Tract or Malignant Gastrointestinal Neuroectodermal Tumor)}

In 1993, Ekfors et al. described the first case of a clear-cell sarcoma in the duodenum [106]. However, a similar case was already reported in 1985 under the term malignant neuroendocrine tumor of the jejunum with osteoclast-like giant cells [107]. In 1998, it became apparent that these tumors share the same genetic characteristics [108], with most tumors harboring an EWSR1-CREB1 fusion and less often an EWSR1-ATF1 fusion [109]. Since then, there has been discussion whether these tumors are CCSs or a separate entity as they have morphological and genetic similarities [21,110-112].

Tumors arise in the gastrointestinal tract (small bowel, stomach, colon, and esophagus) of predominantly young adults and children. However, the age range is broad, including the elderly. An abdominal mass with pain and intestinal obstruction are the main clinical features. Lesions may be large, up to $15 \mathrm{~cm}$. The appear macroscopically firm, solid, and tan-white. Microscopy shows primary involvement of submucosa and muscularis propria, occasionally with mucosal involvement [21,110-112]. Cytomorphology resembles CSS. However, tumors show, besides the nested pattern, arrangement in sheets. Pseudoalveolar, 
pseudopapillary, microcystic, fascicular, and cord-like patterns, and rosette-like structures, are also reported. Mitotic activity is variable. Osteoclast-like giant cells are often numerous [21,110-112]. Immunohistochemistry shows expression of S100 and SOX10. Other melanocytic markers (Melan A, HMB45) are in contrast to CSS commonly absent. Neural and neuroendocrine markers, including synaptophysin, NSE, and CD56, are inconsistently expressed. Rarely dot-like keratin-expression can be observed [21,110-112]. Although there are some differences compared to CCS with regard to morphology and immunophenotype, lack of melanin pigment does not exclude CCS [109]. Another important differential diagnosis regards melanoma. Although molecular alterations can often resolve this matter, not all melanomas harbor a $B R A F$ mutation and not all clear-cell sarcoma-like tumors of the gastrointestinal tract have EWSR1 rearrangements.

These tumors show aggressive behavior with metastases to lymph nodes and the liver [21,110-112].

\subsection{Mesothelioma}

In 2013 a (14;22)(q32;q12) translocation leading to a EWSR1-YY1 fusion was reported in two mesotheliomas, showing for the first time fusion genes in these neoplasms [113]. In 2017, EWSR1/FUS-CREB fusions have been described in a subset of malignant mesotheliomas occurring mainly in young adults [114]. However, the age range is broad, comprising patients from the childhood to the elderly $[113,114]$. There is an equal sex distribution [115]. The peritoneum seems to be mostly involved with pleural lesions less frequently reported [114]. Extension into adjacent organs and structures and lymph node involvement are reported [115]. Histologically, these lesions resemble AFH and in part CSS as described above under these headlines (Figure 9). Additionally, papillary projections, acinar, and tubular structures and psammomatous calcifications are reported as seen in classical mesotheliomas. The cells are epithelioid and histiocytoid with monomorphic round-to-oval nuclei and eosinophilic cytoplasm $[113,115]$. The immunophenotype with keratin- and WT1 nuclear expression and absence of S100 differs from AFH and CSS. Overlapping positive immunohistochemical markers are EMA and desmin. Loss of BAP1 may occur in a minority of cases $[113,115]$. Other differential diagnoses are listed in Table 8. EWSR1/FUS-ATF1/CREM are the described fusion genes showing the spectrum seen in other entities with EWSR1/FUS-CREB [115]. Follow-up data show variable clinical presentation ranging from indolent to aggressive behavior [114,115].

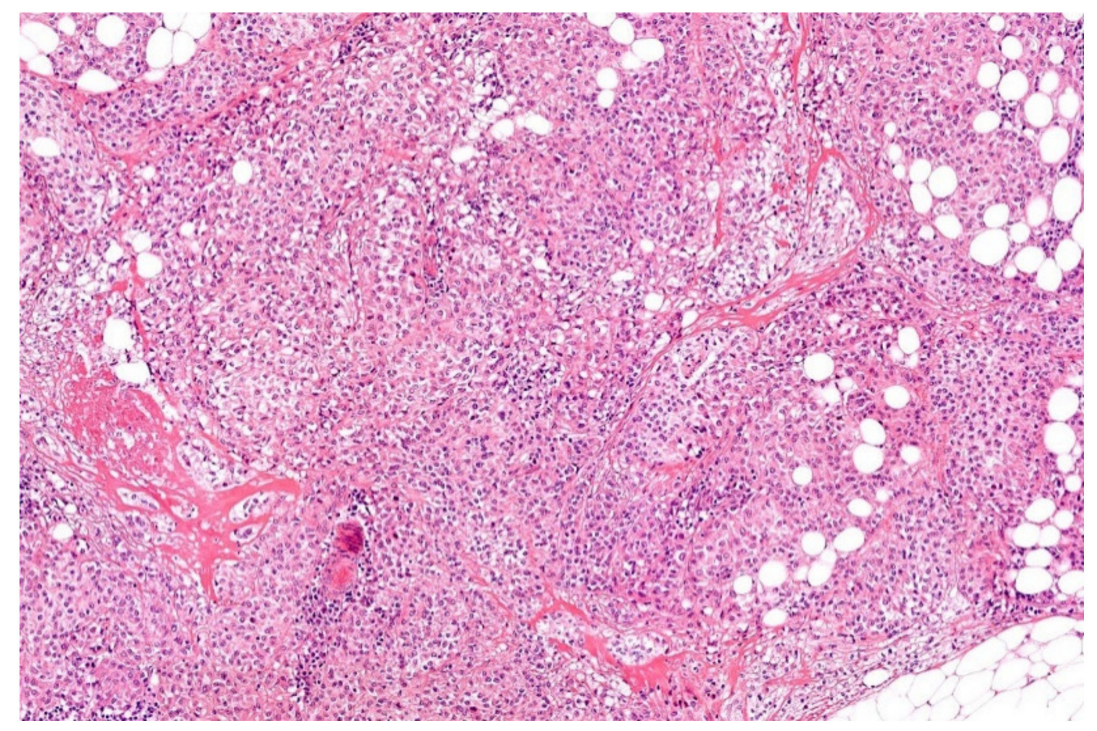

Figure 9. Mesothelioma consist sheets and nests of uniform epitheloid tumor cells with enlarged nuclei and eosinophilic cytoplasm (HE; 20× magnification). 
Table 8. Differential diagnoses of mesothelioma.

\begin{tabular}{|c|c|c|c|}
\hline Diagnosis & Morphology & IHC & $\begin{array}{l}\text { Common Genetic } \\
\text { Alterations }\end{array}$ \\
\hline Clear-cell sarcoma & $\begin{array}{l}\text { Nested-fascicular pattern; } \\
\text { epithelioid-plump spindle } \\
\text { cells with vesicular nuclei and } \\
\text { macronucleoli; fibrous septa; } \\
\text { and scattered wreath-like } \\
\text { multinucleated giant cells }\end{array}$ & $\begin{array}{c}\text { Melanocytic markers (S100, } \\
\text { SOX10, Melan-A, HMB45, } \\
\text { and MITF) }\end{array}$ & $\begin{array}{l}\text { EWSR1-ATF1/CREB (most } \\
\text { often); EWSR1-CREM (rare) }\end{array}$ \\
\hline $\begin{array}{l}\text { Desmoplastic small } \\
\text { round-cell tumor }\end{array}$ & $\begin{array}{l}\text { Sheets/nests/cords of } \\
\text { uniform, small round cells; } \\
\text { and variable } \\
\text { desmoplastic stroma }\end{array}$ & $\begin{array}{l}\text { Desmin (dot-like), keratin, } \\
\text { EMA, and WT1 (C-terminus) }\end{array}$ & EWSR1-WT1 \\
\hline Carcinoma & $\begin{array}{l}\text { Sheets/nests / trabecules; } \\
\text { round-oval-epithelioid cells } \\
\text { with nuclear atypia and } \\
\text { variable cytoplasm }\end{array}$ & $\begin{array}{c}\text { Pankeratins, lineage-specific } \\
\text { markers (depending on site } \\
\text { of origin) }\end{array}$ & $\begin{array}{c}\text { Diverse (depending on site } \\
\text { of origin) }\end{array}$ \\
\hline
\end{tabular}

\section{Myoepithelial Tumors}

Different from most other EWSR1-rearranged neoplasms, myoepithelial tumors have a normal counterpart, with myoepithelial cells being the outer layer of glands present in e.g., salivary glands, lung, skin adnexa, and mamma, but naturally not in soft tissue and bone.

The first myoepithelial tumor of soft tissue was published by Stout and Gorman in 1959 in a series of cutaneous lesions, and the first bone myoepithelioma was reported in 2001 [116,117]. Parachordoma is another term introduced 1977 in the English literature [118]. Reports of cytogenetic analyses showed heterogeneous abnormalities [119-124].

Since EWSR1 rearrangement was mentioned in one myoepithelial carcinoma and one myoepithelioma of soft tissue 2007 and 2008 [125,126]; systematic analyses revealed that approximately $50 \%$ of myoepithelial tumors of skin, soft tissue, viscera, and bone harbor a EWSR1 fusion gene with a variety of gene partners, including PBX1, PBX3, ZNF 444, POU5F1, ATF1, and KLF17 [126-132]. EWSR1 seems to be rarely substituted by FUS [128-130,132]. PLAG1 rearrangement and other genetic changes are alternatively observed [124,133,134].

The age range is broad from early childhood to the elderly. Extremities and limb girdles are most frequently involved, followed by the head and neck and trunk. Skin, subcutis, and deep soft tissue, including mediastinum and retroperitoneum, can be affected [125,135-137]. Bone lesions most often arise in long tubular bones but also in small tubular bones and the axial skeleton, including iliac bone, sacrum, vertebra, ribs, skull, and jaw. Cortical destruction and extension into surrounding soft tissue may be present [138].

Macroscopically, tumors can be large with up to $20 \mathrm{~cm}$. They are usually circumscribed and (multi)nodular. The cut surface often is white-grey in color with gelatinous areas. Calcification and ossification may be seen $[137,138]$.

Microscopy is similar to salivary gland myoepithelial tumors showing a (multi)nodular appearance with well-circumscribed nodi/noduli variably infiltrating adjacent tissue. There is a broad spectrum in terms of architecture, cellularity, and cell composition. Growth patterns, often combined, are solid, nested, reticular, trabecular, cord-like, and glandular. Cells are epithelioid and/or spindled, having sometimes a clear cytoplasm, and/or plasmacytoid, and/or rhabdoid (Figure 10) [135-137]. Lesions called syncytial myoepitheliomas mainly occurring in skin show a sheet-like syncytial growth of ovoid to spindled or histiocytoid cells with pale eosinophilic cytoplasm [139]. Criteria for malignancy were established in the largest series of soft tissue myoepithelial tumors, with tumors with benign cytomorphology or mild atypia (little variation in cell size, small relatively uniform nuclei, fine chromatin, inconspicuous nucleoli) diagnosed as myoepithelioma, whereas morderate 
to servere atypia (nuclear pleomorphism or vesicular or coarse chromatin, prominent nucleoli) represented features of myoepithelial carcinoma [135]. Small round-cell morphology has been described in myoepithelial carcinomas $[125,136,137]$. The matrix, variably present in myoepithelial tumors, can be (chondro)myxoid and/or collagenous/hyaline. Metaplastic cartilage or bone may occur. In myoepithelial carcinomas, malignant bone or cartilage can be observed. High mitotic rate and necrosis is reported in myoepithelial carcinomas [125,136,137].

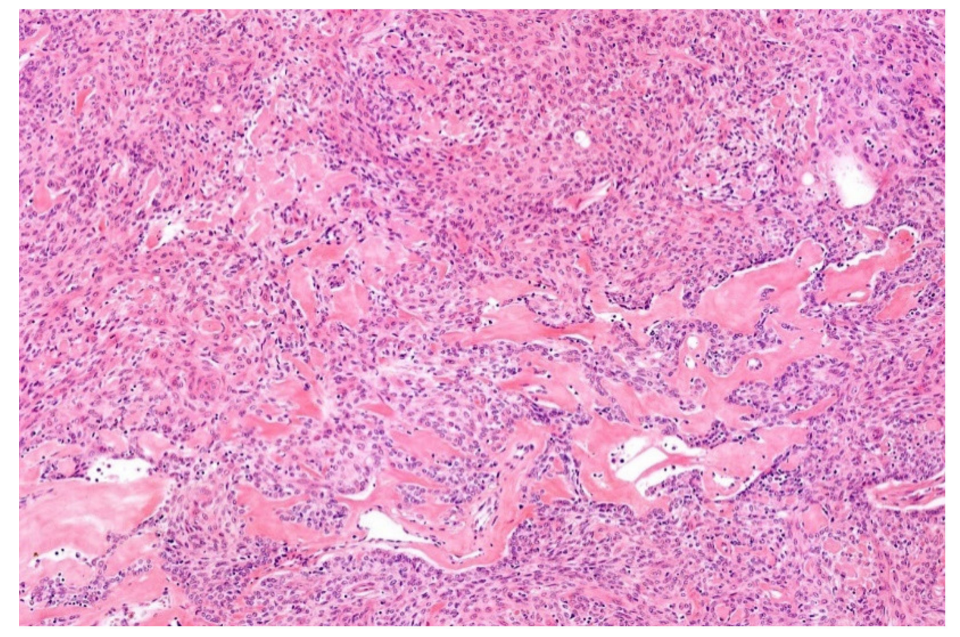

Figure 10. Myoepithelioma: epitheloid and spindle cells are arranged in sheets possessing bland looking nuclei. Note the prominent hyaline matrix (HE; $20 \times$ magnification).

The immunohistochemical profile of myoepithelial tumors is variable showing per definition expression of broad-spectrum keratins and/or EMA and neuronal markers as S100, SOX10, and/or GFAP. P63 is positive in a subset of cases. Smooth muscle markers (SMA, calponin, and desmin) are possibly positive. INI1 is lost in a subset of myoepithelial carcinoma [5]. MUC4 expression can be confusing when considering sclerosing epithelioid fibrosarcoma [130]. Nuclear expression of brachyury, absent in myoepithelial tumors, distinguishes them from chordomas [140]. Differential diagnoses are listed in Table 9.

Table 9. Differential diagnoses of myoepithelial tumors.

\begin{tabular}{|c|c|c|c|}
\hline Diagnosis & Morphology & IHC & $\begin{array}{l}\text { Common Genetic } \\
\text { Alterations }\end{array}$ \\
\hline $\begin{array}{l}\text { Extraskeletal myxoid } \\
\text { chondrosarcoma }\end{array}$ & $\begin{array}{c}\text { Multinodular; } \\
\text { lace-like/reticular pattern; } \\
\text { round-spindle monomorphic } \\
\text { cells with eosinophilic } \\
\text { cytoplasm; and } \\
\text { myxoid stroma }\end{array}$ & Non-specific; S100 (focal) & $\begin{array}{c}\text { NR4A3- } \\
\text { EWSR1/TAF15/TCF12/TFG }\end{array}$ \\
\hline Chordoma & $\begin{array}{l}\text { Lobulated; fibrous septa; } \\
\text { cords/nests of large } \\
\text { epithelioid/polygonal cells, } \\
\text { physaliphorous cells (bubbly } \\
\text { cytoplasm); and variable } \\
\text { myxoid stroma }\end{array}$ & $\begin{array}{c}\text { Cytokeratin, EMA, S100, } \\
\text { Brachyury }\end{array}$ & $\begin{array}{c}\text { Germline tandem duplication } \\
\text { of TBXT (rare); germline } \\
\text { loss-of-function mutations of } \\
\text { TSC1/2 (rare) }\end{array}$ \\
\hline $\begin{array}{l}\text { Sclerosing epitheloid } \\
\text { fibrosarcoma }\end{array}$ & $\begin{array}{l}\text { Infiltrative; cords/nests of } \\
\text { monomorphic epithelioid } \\
\text { cells; and hyalin- } \\
\text { ized/sclerotic/collagenous stroma; }\end{array}$ & MUC4, SMA, and EMA & $\begin{array}{c}\text { EWSR1/FUS/PAX5- } \\
\text { CREB3L1/CREB3L2/CREB3L3/ } \\
\text { CREM }\end{array}$ \\
\hline
\end{tabular}


Table 9. Cont.

\begin{tabular}{|c|c|c|c|}
\hline Diagnosis & Morphology & IHC & $\begin{array}{l}\text { Common Genetic } \\
\text { Alterations }\end{array}$ \\
\hline (Adeno)carcinoma & $\begin{array}{l}\text { Sheets/nests/trabeculae, } \\
\text { glands; round-oval } \\
\text {-epithelioid cells with nuclear } \\
\text { atypia and variable cytoplasm; } \\
\text { and ductular structures } \\
\text { (adenocarcinoma) }\end{array}$ & $\begin{array}{l}\text { Pankeratins, lineage specific } \\
\text { markers (depending on site } \\
\text { of origin) }\end{array}$ & $\begin{array}{l}\text { Diverse (depending on site } \\
\text { of origin) }\end{array}$ \\
\hline Small, blue, round cell tumors & $\begin{array}{l}\text { Cells with small } \\
\text { round-oval-spindle cells with } \\
\text { little cytoplasm }\end{array}$ & Diverse (depending on entity) & See Tables $1-3$ \\
\hline Epitheloid sarcoma & $\begin{array}{l}\text { Nodules of uniform } \\
\text { epithelioid-spindled cells with } \\
\text { eosinophilic cytoplasm; } \\
\text { central geographic necrosis } \\
\text { (classic type); } \\
\text { multinodular/sheet-like } \\
\text { growth; large-slightly } \\
\text { pleomorphic epithelioid cells } \\
\text { with eosinophilic cytoplasm } \\
\text { (proximal type) }\end{array}$ & $\begin{array}{l}\text { CD34, keratins, EMA, and loss } \\
\text { of INI1 }\end{array}$ & Loss of $S M A R C B 1$ \\
\hline Melanoma & $\begin{array}{l}\text { Diverse growth patterns; } \\
\text { large, atypical } \\
\text { spindle-epithelioid-bizarre } \\
\text { cells with vesicular nuclei and } \\
\text { prominent, eosinophilic } \\
\text { nucleoli; nuclear } \\
\text { pseudo-inclusions; abundant } \\
\text { eosinophilic-clear cytoplasm; } \\
\text { and melanin pigment }\end{array}$ & $\begin{array}{l}\text { S100, SOX10, Melan-A, } \\
\text { HMB45, and MITF }\end{array}$ & $\begin{array}{c}\text { Diverse: ARID2, BAP1, BRAF, } \\
\text { GNAQ, HRAS, KIT, NF1, } \\
\text { NRAS, PTEN mutations; and } \\
\text { chromosomal gains/losses }\end{array}$ \\
\hline Epithelioid schwannoma & $\begin{array}{l}\text { Multilobulated growth; } \\
\text { capsule; nests or singly cells; } \\
\text { variable epithelioid cells; and } \\
\text { myxoid-hyalinized stroma }\end{array}$ & $\begin{array}{l}\text { S100, SOX10, and loss of INI1 } \\
(\sim 40 \%)\end{array}$ & Loss of SMARCB1 ( 40\%) \\
\hline $\begin{array}{l}\text { Epitheloid malignant } \\
\text { peripheral nerve sheath tumor }\end{array}$ & $\begin{array}{c}\text { Lobulated growth; atypical } \\
\text { epithelioid cells with enlarged } \\
\text { nuclei; and prominent } \\
\text { nucleoli and } \\
\text { eosinophilic cytoplasm }\end{array}$ & $\begin{array}{l}\text { S100, SOX10 (strong and } \\
\text { diffuse), and loss in INI1 } \\
(\sim 75 \%)\end{array}$ & Loss of SMARCB1 ( 75\%) \\
\hline $\begin{array}{l}\text { Ossifying fibromyxoid tumor } \\
\text { (mostly benign, } \\
\text { rarely malignant) }\end{array}$ & $\begin{array}{l}\text { Multilobulated; nests/cords of } \\
\text { uniform round-spindle cells; } \\
\text { indistinct cytoplasm; no } \\
\text { atypia (rarely high nuclear } \\
\text { grade in malignant lesions); } \\
\text { fibromyxoid stroma; partial } \\
\text { rim of mature bone; and } \\
\text { atypical osteoid in } \\
\text { malignant tumors }\end{array}$ & $\begin{array}{l}\text { S100, desmin, GFAP (focal), } \\
\text { and pankeratin (rare) }\end{array}$ & $\begin{array}{l}\text { PHF1 rearrangements (diverse } \\
\text { fusion partners) }\end{array}$ \\
\hline Clear-cell sarcoma & $\begin{array}{l}\text { Nested-fascicular pattern; } \\
\text { epithelioid-plump spindle } \\
\text { cells with vesicular nuclei and } \\
\text { macronucleoli; fibrous septa; } \\
\text { and scattered wreath-like } \\
\text { multinucleated giant cells }\end{array}$ & $\begin{array}{l}\text { Melanocytic markers (S100, } \\
\text { SOX10, Melan-A, HMB45, } \\
\text { and MITF) }\end{array}$ & $\begin{array}{l}\text { EWSR1-ATF1/CREB (most } \\
\text { often); EWSR1-CREM (rare) }\end{array}$ \\
\hline
\end{tabular}


Table 9. Cont.

\begin{tabular}{|c|c|c|c|}
\hline Diagnosis & Morphology & IHC & $\begin{array}{l}\text { Common Genetic } \\
\text { Alterations }\end{array}$ \\
\hline Malignant rhabdoid tumors & $\begin{array}{l}\text { Solid pattern; uniform } \\
\text { rounded-polygonal cells with } \\
\text { vesicular nuclei and } \\
\text { prominent nucleoli; and } \\
\text { eosinophilic hyaline-like } \\
\text { cytoplasmic inclusions }\end{array}$ & $\begin{array}{c}\text { Diverse; keratins, EMA, CD99, } \\
\text { synaptophysin, SALL4, } \\
\text { glypican-3, and INI1 loss }\end{array}$ & SMARCB1 biallelic loss \\
\hline $\begin{array}{c}\text { Epithelioid } \\
\text { hemangio-endothelioma }\end{array}$ & $\begin{array}{c}\text { Infiltrative, sometimes } \\
\text { angiocentric growth; } \\
\text { cords/nests of bland looking } \\
\text { epithelioid and spindle cells; } \\
\text { glassy cytoplasm; } \\
\text { intracytoplasmic vacuoles } \\
\text { (blister cells); and } \\
\text { myxohyaline stroma }\end{array}$ & $\begin{array}{c}\text { CD34, CD31, ERG, D2-40, } \\
\text { keratins (subset), SMA, } \\
\text { CAMTA1, and TFE3 }\end{array}$ & $\begin{array}{c}\text { WWTR1-CAMTA1 (>90\%); } \\
\text { YAP1-TFE3 }\end{array}$ \\
\hline $\begin{array}{l}\text { Pseudomyogenic (epitheloid } \\
\text { sarcoma-like) } \\
\text { hemangio-endothelioma }\end{array}$ & $\begin{array}{c}\text { Multiple discontinuous } \\
\text { nodules; possibly } \\
\text { involvement of different } \\
\text { tissue planes; sheets/fascicles } \\
\text { of plump-spindle-epithelioid } \\
\text { cells with abundant, brightly } \\
\text { eosinophilic cytoplasm; } \\
\text { vesicular nuclei with small } \\
\text { nucleoli; mild nuclear atypia; } \\
\text { not obvious vascular; and } \\
\text { prominent stromal } \\
\text { neutrophils (50\%) }\end{array}$ & $\begin{array}{l}\text { Keratins (AE1/AE3 but not } \\
\text { MNF116), FLI, ERG, CD31 } \\
(50 \%) \text {, SMA (focal), and FOSB }\end{array}$ & SERPINE1/ACTB-FOSB \\
\hline
\end{tabular}

Excision is the treatment of choice. Most of the lesions are superficially located with a benign morphology behaving indolent. Benign and malignant lesions have the potential for local recurrence. The metastatic rate of myoepithelial carcinoma is high with spread to lung, lymph nodes, bone, and soft tissue. Radiotherapy and chemotherapy are additional treatment options, but clinical effectiveness is variable $[5,137]$.

\section{Low-Grade Fibromyxoid Sarcoma (LGFMS)/Sclerosing Epithelioid Fibrosarcoma (SEF)}

These mostly deep situated sarcomas show overlapping features in terms of morphology, immunohistochemistry, genetic aberrations, and behavior [141]. Therefore, it has been suggested that they form a spectrum of one entity [141,142].

LGFMS was firstly observed by Evans in 1987, and the first description of SEF was done by Meis-Kindblom eight years later $[143,144]$. The chromosomal translocation, most typical for LGFMS, (t7;16)(q34;p11), has been described in 2003 by Reid et al. and the corresponding fusion gene FUS-CREB3L2 in the same year $[145,146]$. Later on, it was shown that CREB3L1 is an alternative fusion partner of FUS and that FUS can be substituted by EWSR1 [147,148]. The genetic findings of LGFMS were also found in SEF and hybrid cases with predominance of EWSR1-CREBL3L1 in SEF [149]. In one case, a PAX5-CREB3L1 was identified [88].

Both entities affect patients over a wide age range with a median in the 3 th (LGFMS) and 4th (SEF) decade [141,142,144,150]. Most often, these tumors occur in the deep soft tissue of the lower extremities, particularly thigh and limb girdles and the trunk. However, a wide variety of involved anatomic sites are reported, including intraabdominal, kidney, and bone [5,141-144,149-153].

Macroscopically, lesions are (multi)nodular with a grey-white whorled cut surface. Myxoid areas, if present, are visible. Infiltrative growth in adjacent structures can be seen $[142,144,151]$. 
Microscopically, LGFMS is characterized by alternating fibrous and myxoid areas with a whorled and bundled growth of uniform bland-looking slender fibroblastic spindle cells with elongated and tapered nuclei. A storiform, fascicular, and patternless architecture may be seen (Figure 11). Mitotic figures are sparse. There is scant cytoplasm. Typically, there are arcades of small blood vessels. In some cases, hyaline rosettes surrounded by round or oval cells are present. Such neoplasms were formerly called hyalinizing spindle cell tumor with giant rosettes. Cellular examples containing epithelioid cells show overlap with SEF and hybrid cases occur. A shift of the LGFMS pattern to SEF morphology is described in recurrences and metastases. Uncommonly noted are cell clusters, strands, palisades, and a retiform pattern. Thick collagen bundles are sometimes found in fibrotic areas. Nuclear pleomorphism and multinucleated giant cells are rarely observed and are mainly associated with recurrences and metastases. Cystic changes and osseous metaplasia may occur $[141,143,150,151]$.

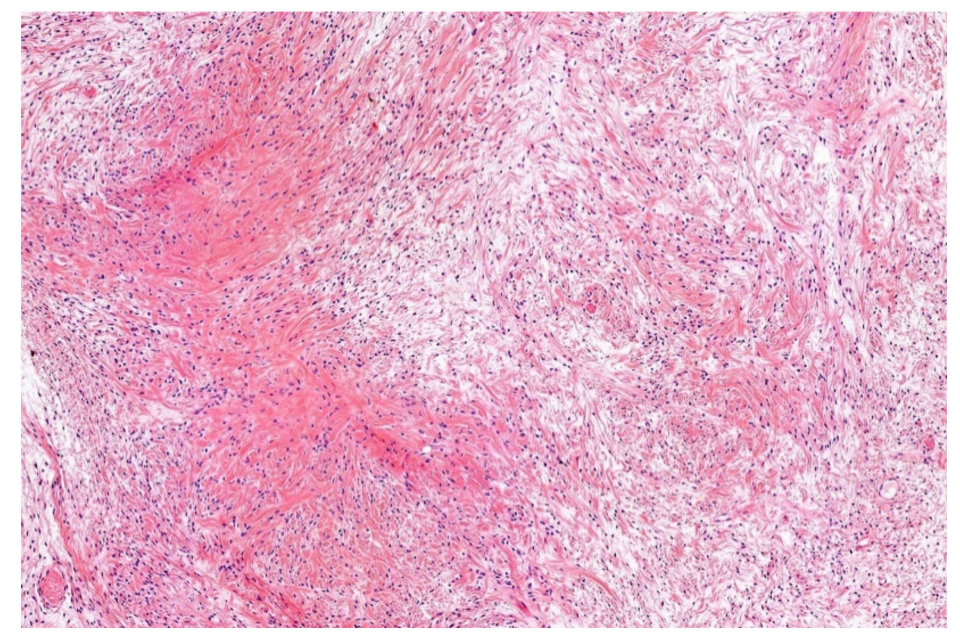

Figure 11. Low-grade fibromyoid sarcomas are characterized by bland looking spindle cells set in an alternating fibromyxoid matrix (HE; $20 \times$ magnification).

SEF shows histomorphologically epithelioid/polygonal cells arranged in cords, nests, and sheets situated in a sclerotic stroma. Due to cellular shrinkage, a pseudovascular appearance can become apparent. The round-to-oval nuclei show at most slight pleomorphism and an open chromatin. There is a variable often low mitotic count (Figure 12) [141,142,144]. Chondro-osseous differentiation is exceptionally observed [144,149].

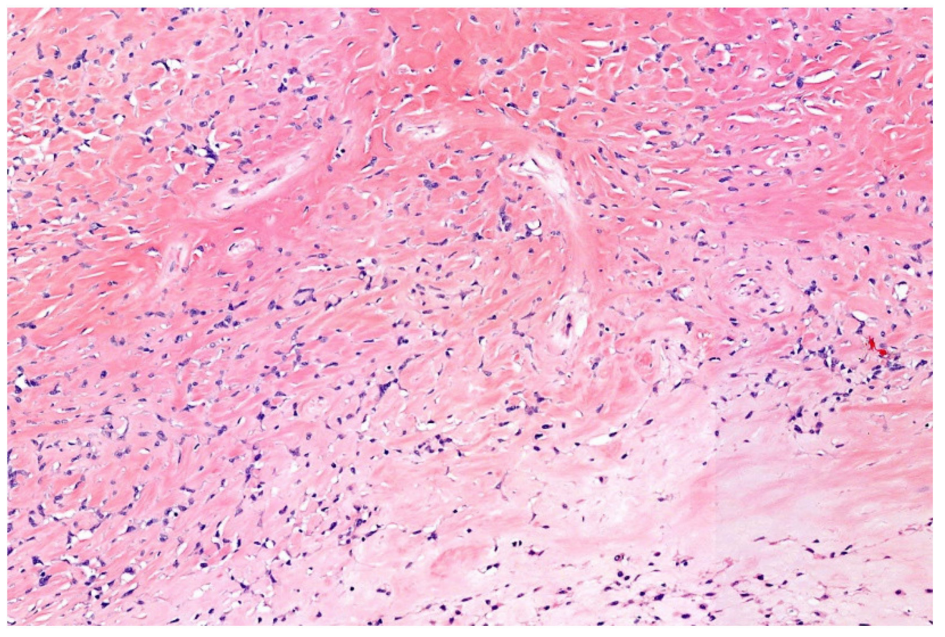

Figure 12. Sclerosing epitheloid fibrosarcoma, demonstrated by cords of bland looking epitheloid cells in a sclerotic stroma. Note pseudoangiomatous shrinkage artefacts ( $20 \times$ magnification). 
The most reliable immunohistochemical marker is MUC4 with positivity in the majority of LGFMS, whereas SEFs are positive in around 70\% of the cases $[149,154,155]$. Other markers such as EMA, S100, CD34, SMA, and keratins (in SEF) are inconsistently expressed [141].

Differential diagnoses are listed in Tables 10 and 11.

Wide excision is the treatment of choice. LGFMS typically shows a prolonged clinical course with recurrences and metastases. SEF seems to be more aggressive with much shorter survival; however, the outcome is variable [141,150].

Table 10. Differential diagnoses of LGFMS.

\begin{tabular}{|c|c|c|c|}
\hline Diagnosis & Morphology & IHC & $\begin{array}{l}\text { Common Genetic } \\
\text { Alterations }\end{array}$ \\
\hline Desmoid-type fibromatosis & $\begin{array}{l}\text { Long, sweeping fascicles; } \\
\text { slender uniform spindle cells; } \\
\text { pale cytoplasm; and parallel } \\
\text { to fascicles thin-walled blood } \\
\text { vessels with perivascular } \\
\text { edema }\end{array}$ & $\begin{array}{l}\text { Beta-catenin (nuclear), SMA, } \\
\text { and desmin (focal) }\end{array}$ & CTNNB1 or APC mutations \\
\hline Nodular fasciitis & $\begin{array}{c}\text { Plump spindle cells; } \\
\text { tissue-culture aspect; } \\
\text { extravasated erythrocytes; } \\
\text { lymphocytes; and sometimes } \\
\text { osteoclast-like giant cells }\end{array}$ & $\begin{array}{l}\text { Non-specific: SMA, CD68, } \\
\text { and desmin (focal) }\end{array}$ & $\begin{array}{l}\text { USP6 rearrangements (diverse } \\
\text { fusion partners) }\end{array}$ \\
\hline $\begin{array}{l}\text { Ossifying fibromyxoid tumor } \\
\text { (mostly benign, } \\
\text { rarely malignant) }\end{array}$ & $\begin{array}{l}\text { Multilobulated; nests/cords of } \\
\text { uniform round-spindle cells; } \\
\text { indistinct cytoplasm; no } \\
\text { atypia (rarely high nuclear } \\
\text { grade in malignant lesions); } \\
\text { fibromyxoid stroma; partial } \\
\text { rim of mature bone; and } \\
\text { atypical osteoid in } \\
\text { malignant tumors }\end{array}$ & $\begin{array}{l}\text { S100, desmin, GFAP (focal), } \\
\text { and pankeratin (rare) }\end{array}$ & $\begin{array}{l}\text { PHF1 rearrangements (diverse } \\
\text { fusion partners) }\end{array}$ \\
\hline Neurofibroma & $\begin{array}{l}\text { Nodular or diffuse growth; } \\
\text { variable admixture of } \\
\text { perineurial cells, schwann } \\
\text { cells and fibroblasts; } \\
\text { hyperchromasia; usually no } \\
\text { atypia or mitoses; and } \\
\text { myxoid-collagenous } \\
\text { stroma with } \\
\text { "shredded-carrot" collagen }\end{array}$ & S100, SOX10, CD34, and EMA & NF1 deletions \\
\hline Perineurioma & $\begin{array}{l}\text { Nodular; non-encapsulated; } \\
\text { circumscribed or infiltrative; } \\
\text { whorled/storiform/fascicular } \\
\text { pattern; and slender spindle } \\
\text { cells with bipolar cytoplasmic } \\
\text { extensions and uniform oval } \\
\text { or elongated nuclei }\end{array}$ & $\begin{array}{l}\text { EMA, GLUT1, CD34, and } \\
\text { Claudin } 1\end{array}$ & $\begin{array}{c}\text { TRAF7 mutations (intraneural } \\
\text { perineurioma); } \\
\text { NF1/2 deletions }\end{array}$ \\
\hline Desmoplastic fibroblastoma & $\begin{array}{l}\text { Paucicellular; bland } \\
\text { stellate-spindle cells; and } \\
\text { abundant collagenous- } \\
\text { myxocollagenous stroma }\end{array}$ & FOSL1, SMA (focal) & $\mathrm{t}(2 ; 11)$ \\
\hline
\end{tabular}


Table 10. Cont.

\begin{tabular}{|c|c|c|c|}
\hline Diagnosis & Morphology & IHC & $\begin{array}{l}\text { Common Genetic } \\
\text { Alterations }\end{array}$ \\
\hline $\begin{array}{l}\text { Malignant peripheral nerve } \\
\text { sheath tumor }\end{array}$ & $\begin{array}{l}\text { Fascicles of monomorphic } \\
\text { atypical spindle cells with } \\
\text { perivascular accentuation and } \\
\text { alternating cellularity; } \\
\text { pleomorphism is possible; } \\
\text { staghorn vessels; geographic } \\
\text { necrosis; and heterologous } \\
\text { differentiation }\end{array}$ & $\begin{array}{c}\text { S100, SOX10 (focal), and loss } \\
\text { of H3K } 27 \mathrm{me} 3\end{array}$ & $\begin{array}{c}\text { Inactivating mutations of } N F 1 \text {, } \\
C D K N 2 A / B, E E D \text {, and } S U Z 2\end{array}$ \\
\hline Fibroma nuchae & $\begin{array}{l}\text { Paucicellular; bland spindle } \\
\text { cells; thick collagen bundles; } \\
\text { and entrapped adipose tissue } \\
\text { and/or small nerves }\end{array}$ & CD34 & Not relevant \\
\hline $\begin{array}{l}\text { Intramuscular (cellular) } \\
\text { myxoma }\end{array}$ & $\begin{array}{l}\text { Myxoid stroma; hypocellular; } \\
\text { uniform spindle-stellate cells; } \\
\text { inconspicuous vessels; and } \\
\text { infiltration into } \\
\text { skeletal muscle }\end{array}$ & CD34 & GNAS mutations \\
\hline $\begin{array}{l}\text { Dermatofibrosarcoma } \\
\text { protuberans }\end{array}$ & $\begin{array}{l}\text { Dermal based; cellular, } \\
\text { storiform pattern of uniform } \\
\text { spindle cells; encasement of } \\
\text { skin appendages; and } \\
\text { infiltration in subcutaneous } \\
\text { fat with honeycombing }\end{array}$ & CD34 & $\begin{array}{c}\text { COL1A1-PDGFB (most often); } \\
\text { COL6A3-PDGFD or } \\
\text { EMILIN2-PDGFD (rare) }\end{array}$ \\
\hline $\begin{array}{l}\text { NTRK-rearranged spindle cell } \\
\text { neoplasm (emerging) }\end{array}$ & $\begin{array}{c}\text { Wide spectrum of } \\
\text { morphologies and histological } \\
\text { grades; most often } \\
\text { haphazardly arranged } \\
\text { monomorphic spindle cells; } \\
\text { variable stromal/perivascular } \\
\text { hyalinization; and infiltrative } \\
\text { growth into fat }\end{array}$ & $\begin{array}{l}\text { S100, CD34 (co-expression), } \\
\text { and NTRK }\end{array}$ & $\begin{array}{c}\text { NTRK1-3 rearrangements } \\
\text { (diverse fusion partners); } \\
R A F 1 \text { or BRAF fusions (rare) }\end{array}$ \\
\hline
\end{tabular}

Table 11. Differential diagnoses of SEF.

\begin{tabular}{|c|c|c|c|}
\hline Diagnosis & Morphology & IHC & $\begin{array}{l}\text { Common Genetic } \\
\text { Alterations }\end{array}$ \\
\hline Ossifying fibromyxoid tumor & $\begin{array}{l}\text { Multilobulated; nests/cords of } \\
\text { uniform round-spindle cells; } \\
\text { indistinct cytoplasm; no } \\
\text { atypia (rarely high nuclear } \\
\text { grade in malignant lesions); } \\
\text { fibromyxoid stroma; partial } \\
\text { rim of mature bone; and } \\
\text { atypical osteoid in } \\
\text { malignant tumors }\end{array}$ & $\begin{array}{l}\text { S100, desmin, GFAP (focal), } \\
\text { and pankeratin (rare) }\end{array}$ & $\begin{array}{l}\text { PHF1 rearrangements (diverse } \\
\text { fusion partners) }\end{array}$ \\
\hline $\begin{array}{l}\text { Carcinoma (lobular, signet } \\
\text { ring cell) }\end{array}$ & $\begin{array}{l}\text { Files-small nests; round-oval } \\
\text { cells with variable cytoplasm } \\
\text { and nuclear atypia; and } \\
\text { intracytoplasmic } \\
\text { mucin vacuole }\end{array}$ & $\begin{array}{l}\text { Pankeratins, lineage specific } \\
\text { markers (depending on site } \\
\text { of origine) }\end{array}$ & $\begin{array}{l}\text { Diverse (depending on site } \\
\text { of origin) }\end{array}$ \\
\hline Sclerosing lymphoma & $\begin{array}{l}\text { Variably sized } \\
\text { hyperchromatic-blastoid cells } \\
\text { with variable atypia; scant } \\
\text { cytoplasm; and } \\
\text { sclerotic stroma }\end{array}$ & CD45, B/T-cell markers & Diverse \\
\hline
\end{tabular}


Table 11. Cont.

\begin{tabular}{|c|c|c|c|}
\hline Diagnosis & Morphology & IHC & $\begin{array}{l}\text { Common Genetic } \\
\text { Alterations }\end{array}$ \\
\hline Synovial sarcoma & $\begin{array}{c}\text { Sheets-fascicles; cellular, } \\
\text { monomorphic spindle cells; } \\
\text { high N/C ratio, variable } \\
\text { epithelial differentiation; } \\
\text { staghorn vessels; variable } \\
\text { amount of collagen; mast cells; } \\
\text { and calcification/ossification; } \\
\text { poorly differentiated areas } \\
\text { may show } \\
\text { round-epithelioid cells }\end{array}$ & $\begin{array}{l}\text { CD99, BCL2, CD56, TLE1, } \\
\text { S100 (focal), EMA, and } \\
\text { keratins (variable) }\end{array}$ & SS18-SSX1/2/4 \\
\hline Clear-cell sarcoma & $\begin{array}{l}\text { Nested-fascicular pattern; } \\
\text { epithelioid-plump spindle } \\
\text { cells with vesicular nuclei and } \\
\text { macronucleoli; fibrous septa; } \\
\text { and scattered wreath-like } \\
\text { multinucleated giant cells }\end{array}$ & $\begin{array}{c}\text { Melanocytic markers (S100, } \\
\text { SOX10, Melan-A, HMB45, } \\
\text { and MITF) }\end{array}$ & $\begin{array}{l}\text { EWSR1-ATF1/CREB (most } \\
\text { often); EWSR1-CREM (rare) }\end{array}$ \\
\hline Osteosarcoma & $\begin{array}{l}\text { Highly diverse; infiltrative } \\
\text { growth; severely anaplastic } \\
\text { and pleiomorphic cells; } \\
\text { monomorphic small cell } \\
\text { appearance is rare; and } \\
\text { atypical neoplastic bone } \\
\text { formation (essential) }\end{array}$ & $\begin{array}{l}\text { SATB2, osteocalcin (BGLAP), } \\
\text { osteonectin (SPARC), } \\
\text { osteoprotegerin (TNFRSF11B), } \\
\text { RUNX2, S100, actins, CD99, } \\
\text { keratin, and EMA }\end{array}$ & $\begin{array}{l}\text { Highly complex } \\
\text { chromosomal aneuploidy }\end{array}$ \\
\hline Myoepithelioma & $\begin{array}{c}\text { Divers spectrum; } \\
\text { reticular/trabecular } \\
\text { pattern; variable } \\
\text { spindle/epithelioid/clear/ } \\
\text { plasmocytoid/rhabdoid cells; } \\
\text { rarely ductal component } \\
\text { (mixed tumors); fibromyxoid } \\
\text { stroma; and hyalinization }\end{array}$ & $\begin{array}{c}\text { Pankeratins, S100, EMA, } \\
\text { GFAP, SOX10, P63, SMA, } \\
\text { calponin, and desmin (focal) }\end{array}$ & $\begin{array}{l}\text { EWSR1 rearrangements } \\
\text { (various fusion partners); } \\
\text { PLAG1 rearrangements } \\
\text { (mixed tumors) }\end{array}$ \\
\hline
\end{tabular}

\section{Extraskeletal Myxoid Chondrosarcoma (EMC)}

When initially described by Stout and Verner in 1953, it was thought that EMCs are true chondrosarcomas [156]. The first large series delineating this tumor type more precisely was published by Enzinger and Shiraki in 1972 [157]. In 1985, Hinrichs et al. reported for the first time the specific reciprocal translocation $t(9 ; 22)(q 22 ; q 11)$ leading to the most common fusion gene EWSR1-NR4A3, which was detected by Labelle et al. 1995 [158,159]. It seems that $N R 4 A 3$ is necessarily involved. The described fusion partners besides EWSR1 are TAF15, TCF12, and TFG [160,161].

This in deep subcutis and soft tissue located sarcoma affects adults with a mean age of 50 years. Children are rarely involved [162,163]. Males are slightly more often affected [160]. The main sites are the proximal extremities and limb girdles followed by the distal extremities and trunk. Unusual sites are the head and neck area, including the intracranial cavity, the pelvic cavity/retroperitoneum, or intraabdominal and acral sites [21,160,162]. Rarely bone lesions are also reported [164].

Macroscopically, tumors show a (multi)nodular configuration with relatively welldefined margins and variably a pseudocapsule. The cut-surface appears gelatinous with a tan color. Firm grey-white areas and hemorrhage may be seen [160].

Regarding microscopy, EMC is commonly a hypocellular lesion characterized by a multinodular growth pattern with presence of fibrous septa. The tumor nodules show peripheral accentuation of cellularity and are composed of bland-looking small round-tospindled cells with scanty eosinophilic cytoplasm set in a myxoid matrix resulting in a 
lace-like or reticular appearance. The nuclei are usually uniform, round-to-oval with an open chromatin or with hyperchromasia (Figure 13). There is low mitotic activity. Cellular areas lose their classical architecture owing to the limited myxoid matrix. They may be present in primary and recurrent lesions sometimes associated with pleomorphism of epithelioid, rhabdoid, and spindled cells [160,162].

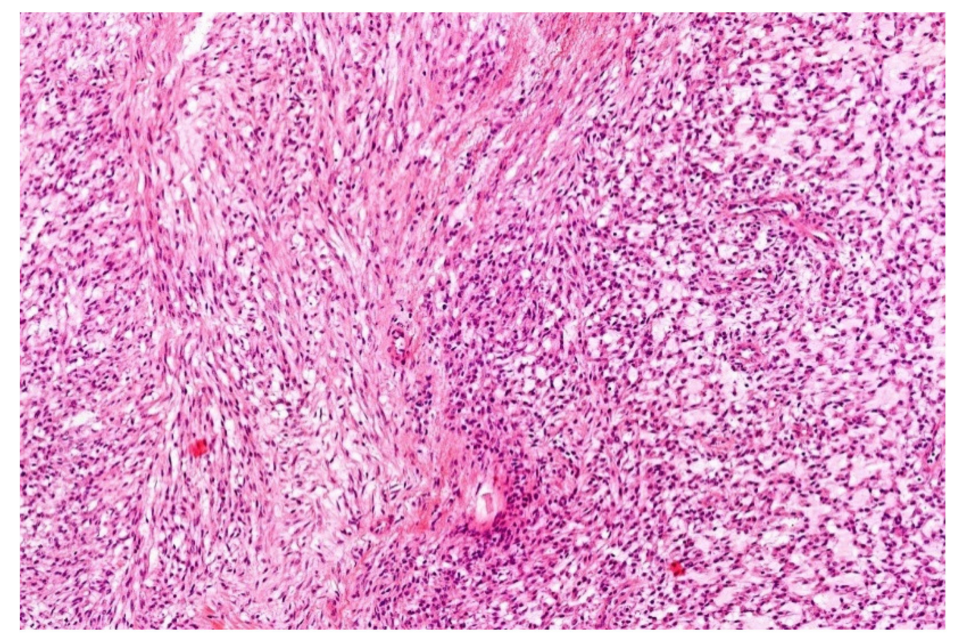

Figure 13. Extraskeletal myxoid chondrosarcoma shows a lace-like architecture due to the myxoid matrix. There are monomorphic epitheloid and spindle cells with an obvious eosinophilic cytoplasm (HE; 20× magnification).

Immunohistochemistry is of little value depicting focal S100 reaction. GFAP, EMA, SMA, keratins, and p63 are expressed in a minority of cases with a focal staining pattern $[160,161]$. Fusion gene analyses is especially helpful when classical features are less obvious.

The most important differential diagnosis is myoepithelial tumors of soft tissue. They show morphological, immunophenotypical (EMA/Keratins + and S100/SOX10/GFAP+), and genetic overlap with rearrangement of EWSR1 in a subset of cases. Fusion chimera involving $N R 4 A 3$ are confirmatory for the diagnosis of EMC [161]. For further differential diagnoses see Table 9.

Surgery is the treatment of choice. EMC shows a protracted clinical course with a high rate of recurrences and metastatic potential [21,162,165].

\section{EWSR1-SMAD3-Positive Fibroblastic Tumor (ESFT)}

This recently defined tumor type was first described by Kao et al. in 2018 [166]. Few reports have followed since then [167-171].

Lesions usually present as a relatively small painless mass in the skin and superficial soft tissue of the extremities, mainly distal, especially the foot. Occurrence in bone is reported in one case localized in the tibia [171]. There is a broad age range from the early childhood to the elderly and an obvious female preponderance.

Macroscopically, the neoplasms are nodular and firm, showing on cut surface a whitegrey solid appearance.

Histologically, tumors have a nodular configuration and consist of infiltrative growing intersecting long or short fascicles. The spindle cells possess uniform elongated nuclei with open chromatin. Mitotic activity is low. There is inconspicuous cytoplasm. Cellular areas merge with hyalinized areas showing sometimes calcifications. In some cases, a zonation pattern is seen often with central hyalinization (Figure 14). When located intradermal, an epidermal collarette may be present. Arrangement around blood vessels as seen in myopericytomas is sometimes observed. Myxoid and collagenous areas with the latter reminiscent of collagen rosettes are rarely reported [167-171]. 


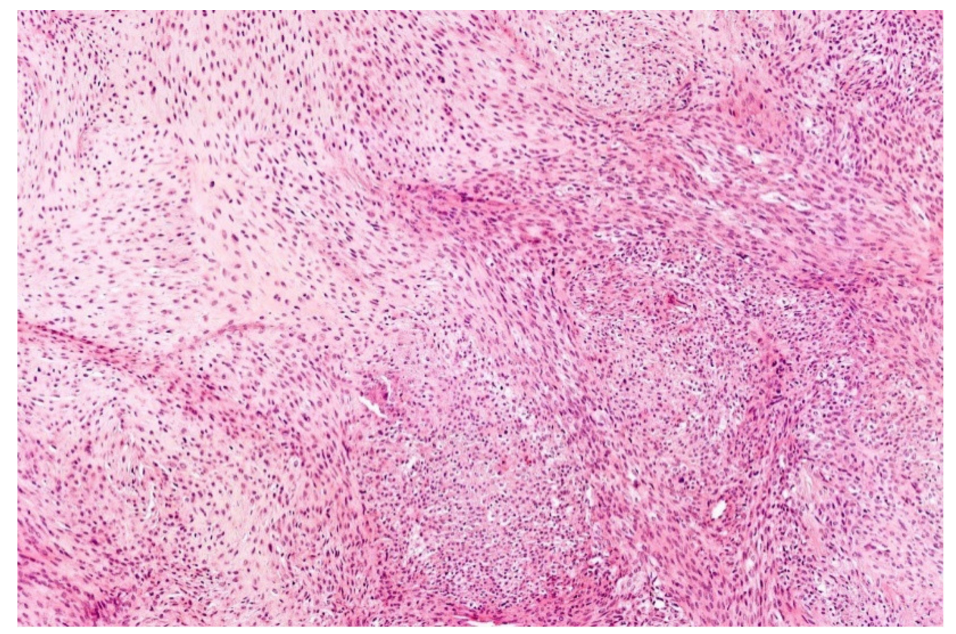

Figure 14. EWSR1-SMAD3-positive fibroblastic tumor is composed of fascicles of bland looking spindle cells. There is an alternating cellularity with a hyaline matrix (HE; $20 \times$ magnification).

Immunohistochemically, the most reliable marker by now seems to be ERG demonstrating an homogeneous nuclear expression. Variable positive markers are SMA, keratins (both mostly week and focal), and SATB2. Reported negative stainings are EMA, desmin, S100, SOX10, CD34, CD31, MUC4, STAT6, TLE1, HMB45, and CD99. When a classical clinicopathologic constellation is present with expression of ERG, the diagnosis is straight forward. However fusion gene analysis may aid for the precise diagnosis, because benign and malignant lesions are in the differential diagnoses listed in Table 12 [167-171].

Table 12. Differential diagnoses of EWSR1-SMAD3-positive fibroblastic tumor.

\begin{tabular}{|c|c|c|c|}
\hline Diagnosis & Morphology & IHC & $\begin{array}{l}\text { Common Genetic } \\
\text { Alterations }\end{array}$ \\
\hline Cellular schwannoma & $\begin{array}{c}\text { Encapsulation; } \\
\text { predominantly Antoni A } \\
\text { areas; variable neuroid } \\
\text { spindle cells; possibly } \\
\text { hyperchromasia and frequent } \\
\text { mitoses; rarely Verocay bodies } \\
\text { or schwannian whorls; and } \\
\text { hyalinized vessels } \\
\text { subcapsular lymphocytes }\end{array}$ & S100, SOX10 & $\begin{array}{l}\text { NF2 deletion; } L A T S 1 / 2, \\
\text { ARID1A/1B, and } \\
\text { DDR1 mutations; } \\
\text { SH3PXD2A-HTRA1 }\end{array}$ \\
\hline Perineurioma & $\begin{array}{l}\text { Whorled/storiform pattern; } \\
\text { slender spindle cell with } \\
\text { bipolar cytoplasmic } \\
\text { extensions and } \\
\text { oval/elongated } \\
\text { uniform nuclei }\end{array}$ & $\begin{array}{l}\text { EMA, GLUT1, CD34, } \\
\text { Claudin } 1\end{array}$ & $\begin{array}{l}\text { TRAF7 mutations (intraneural } \\
\text { perineurioma); NF/2 deletions }\end{array}$ \\
\hline Myofibroma/myopericytoma & $\begin{array}{l}\text { Myofibroma: nodular; } \\
\text { biphasic pattern: immature } \\
\text { plump-spindle cells around } \\
\text { staghorn vessels; and } \\
\text { nodules/fascicles of } \\
\text { hyalinized-myoid-chondroid } \\
\text { appearing cells. } \\
\text { Myopericytoma: lobular; } \\
\text { variably cellular; bland } \\
\text { oval-spindle-myoid cells; and } \\
\text { perivascular growth }\end{array}$ & $\begin{array}{c}\text { SMA (myofi- } \\
\text { broma/myopericytoma), } \\
\text { caldesmon (myopericytoma) }\end{array}$ & $\begin{array}{c}\text { PDGFRB, } \\
\text { SOTCH3 mutations; } \\
\text { SRF-RELA }\end{array}$ \\
\hline
\end{tabular}


Table 12. Cont.

\begin{tabular}{|c|c|c|c|}
\hline Diagnosis & Morphology & IHC & $\begin{array}{l}\text { Common Genetic } \\
\text { Alterations }\end{array}$ \\
\hline Angioleiomyoma & $\begin{array}{l}\text { Bundles of bland } \\
\text { leiomyocytes around } \\
\text { numerous vessels }\end{array}$ & $\begin{array}{l}\text { SMA, calponin, caldesmon, } \\
\text { and desmin (variable) }\end{array}$ & Not relevant \\
\hline Cellular digital fibroma & $\begin{array}{l}\text { Whorls/short fascicles; bland } \\
\text { spindle cells with slightly } \\
\text { eosinophilic cytoplasm; pale } \\
\text { pink-red, paranuclear } \\
\text { inclusions; and } \\
\text { collagenous stroma }\end{array}$ & $\begin{array}{l}\text { Actin, calponin, } \\
\text { and caldesmon }\end{array}$ & Not relevant \\
\hline $\begin{array}{l}\text { Calcifying aponeurotic } \\
\text { fibroma }\end{array}$ & $\begin{array}{l}\text { Fibromatosis-like, infiltrative } \\
\text { component of bland spindle } \\
\text { cells; nodular calcified } \\
\text { component with } \\
\text { hyalinized-chondroid matrix } \\
\text { encircled by } \\
\text { rounded-chondrocyte like } \\
\text { cells; and osteoclast-type } \\
\text { giant cells }\end{array}$ & $\begin{array}{l}\text { SMA, CD99, S100 } \\
\text { (chondroid areas) }\end{array}$ & FN1-EGF \\
\hline Acral fibromyxoma & $\begin{array}{c}\text { Nodular or diffuse; infiltrative } \\
\text { growth of bland } \\
\text { spindle-stellate cells; and } \\
\text { variably } \\
\text { myxoid-collagenous stroma }\end{array}$ & $\begin{array}{l}\text { CD34, EMA, SMA, and } \\
\text { RB1 (loss) }\end{array}$ & RB1 deletions \\
\hline Superficial fibromatosis & $\begin{array}{l}\text { Plexiform or multinodular; } \\
\text { moderately cellular bland } \\
\text { spindle cells; and } \\
\text { collagenous stroma }\end{array}$ & $\begin{array}{l}\text { SMA, desmin, beta-catenin } \\
\text { (nuclear) positive in a subset } \\
\text { of cases despite absence of } \\
\text { CTNNB1 or APC mutation }\end{array}$ & Not relevant \\
\hline Cellular dermatofibroma & $\begin{array}{l}\text { Radiar configuration; } \\
\text { storiform/short fascicular } \\
\text { pattern; cellular center of } \\
\text { fibrohistiocytic cells; and } \\
\text { peripheral } \\
\text { collagen entrapment }\end{array}$ & SMA, FXIIA, and CD68 & $\begin{array}{c}\text { PRKCB/PRKCD- } \\
\text { PDPN/CD63/LAMTOR1 }\end{array}$ \\
\hline Lipofibromatosis & $\begin{array}{l}\text { Admixture of mature fat, } \\
\text { fascicles of bland } \\
\text { myofibroblastic spindle cells } \\
\text { (fibromatosis-like) and } \\
\text { lipoblast-like cells at } \\
\text { the interface }\end{array}$ & CD34, SMA & $\begin{array}{c}\text { EGFR/HER1/ROS/RET/ } \\
\text { PDGFRB-EGF/HBEGF/TGF- } \alpha\end{array}$ \\
\hline Smooth muscle neoplams & $\begin{array}{c}\text { Intersecting fascicles of } \\
\text { smooth muscle cells; } \\
\text { blunt-ended, cigar-shaped } \\
\text { nuclei; and } \\
\text { eosinophilic cytoplasm }\end{array}$ & SMA, desmin, and caldesmon & Not relevant; \\
\hline Synovial sarcoma & $\begin{array}{c}\text { Sheets-fascicles; cellular, } \\
\text { monomorphic spindle cells; } \\
\text { high N/C ratio; variable } \\
\text { epithelial differentiation; } \\
\text { staghorn vessels; variable } \\
\text { amount of collagen; mast cells; } \\
\text { calcification/ossification; and } \\
\text { poorly differentiated areas } \\
\text { may show } \\
\text { round-epithelioid cells }\end{array}$ & $\begin{array}{l}\text { CD99, BCL2, CD56, TLE1, } \\
\text { S100 (focal), EMA, and } \\
\text { keratins (variable) }\end{array}$ & SS18-SSX1/2/4 fusion \\
\hline
\end{tabular}


Table 12. Cont.

\begin{tabular}{|c|c|c|c|}
\hline Diagnosis & Morphology & IHC & $\begin{array}{l}\text { Common Genetic } \\
\text { Alterations }\end{array}$ \\
\hline $\begin{array}{l}\text { Malignant peripheral nerve } \\
\text { sheath tumor }\end{array}$ & $\begin{array}{l}\text { Fascicles of spindle cells with } \\
\text { perivascular accentuation and } \\
\text { alternating cellularity; } \\
\text { staghorn vessels; georgraphic } \\
\text { necrosis; and heterologous } \\
\text { differentiation }\end{array}$ & $\begin{array}{c}\text { S100, SOX10 (focal), and loss } \\
\text { of H3K } 27 \mathrm{me} 3\end{array}$ & $\begin{array}{c}\text { Inactivating mutations of } N F 1 \text {, } \\
C D K N 2 A / B, E E D \text {, and } S U Z 2\end{array}$ \\
\hline $\begin{array}{c}\text { Acral dermatofibrosarcoma } \\
\text { protuberans }\end{array}$ & $\begin{array}{l}\text { Dermal-based; cellular, } \\
\text { storiform pattern of uniform } \\
\text { spindle cells; encasement of } \\
\text { skin appendages; and } \\
\text { infiltration in subcutaneous } \\
\text { fat with honeycombing }\end{array}$ & CD34 & $\begin{array}{l}\text { COL1A1-PDGFB fusion (most } \\
\text { often); COL6A3-PDGFD or } \\
\text { EMILIN2-PDGFD (rare) }\end{array}$ \\
\hline $\begin{array}{l}\text { Low-grade fibromyxoid } \\
\text { sarcoma }\end{array}$ & $\begin{array}{l}\text { Alternating myxoid-fibrous } \\
\text { areas; whorling/fascicular } \\
\text { pattern of bland spindle cells; } \\
\text { arcades of small vessels; and } \\
\text { sometimes hyaline rosettes, } \\
\text { which sometimes overlap } \\
\text { with sclerosing epitheloid } \\
\text { fibrosarcoma }\end{array}$ & $\begin{array}{l}\text { MUC4 (highly sensitive and } \\
\text { specific); EMA, S100, CD34, } \\
\text { and SMA (variable) }\end{array}$ & EWSR1/FUS-CREB3L1/2 \\
\hline $\begin{array}{l}\text { Pseudomyogenic (epitheloid } \\
\text { sarcoma-like) } \\
\text { hemangioendothelioma }\end{array}$ & $\begin{array}{l}\text { Multiple discontinuous } \\
\text { nodules; possible involvement } \\
\text { of different tissue planes; } \\
\text { sheets/fascicles of } \\
\text { plump-spindle-epithelioid } \\
\text { cells with abundant, brightly } \\
\text { eosinophilic cytoplasm; } \\
\text { vesicular nuclei with small } \\
\text { nucleoli; mild nuclear atypia; } \\
\text { not obvious vascular; and } \\
\text { prominent stromal } \\
\text { neutrophils }(50 \%)\end{array}$ & $\begin{array}{l}\text { Keratins (AE1/AE3 but not } \\
\text { MNF116), FLI, ERG, CD31 } \\
(50 \%), \text { SMA (focal), and FOSB }\end{array}$ & SERPINE1/ACTB-FOSB \\
\hline $\begin{array}{l}\text { NTRK-rearranged spindle } \\
\text { cell neoplasms }\end{array}$ & $\begin{array}{c}\text { Wide spectrum of } \\
\text { morphologies and histological } \\
\text { grades; most often } \\
\text { haphazardly arranged } \\
\text { monomorphic spindle cells; } \\
\text { variable stromal/perivascular } \\
\text { hyalinization; and infiltrative } \\
\text { growth into fat }\end{array}$ & $\begin{array}{c}\text { S100, CD34 (co-expression), } \\
\text { and NTRK }\end{array}$ & $\begin{array}{c}\text { NTRK1-3 rearrangements } \\
\text { (diverse fusion partners); } \\
\text { RAF1 or BRAF fusions (rare) }\end{array}$ \\
\hline
\end{tabular}

The clinical behavior appears to be benign, also when located in the bone, but lesions are prone to local recurrence even after 10 years [167-171].

\section{Epithelioid and Spindle Cell Rhabdomyosarcoma with EWSR1/FUS-TFCP2 Fusion}

These lesions were first described by Watson et al. in 2018 [26].

Hitherto-reported cases arose mainly in the bone and rarely in soft tissue, with predilection for the craniofacial bones. However, sites are heterogeneous, including also pelvis, femur, groin, and peritoneum. Intraosseous lesions show destruction of the cortex and expansion into soft tissue. The age range is broad, including pediatric patients and elderly patients. The average age is in the third decade. Males and females are affected (almost) equally with a slight female preponderance [172].

Macroscopically, a solid mass is reported [173]. 
Histologically, tumors consist of epithelioid and/or spindle cells. Whereas epithelioid cells are arranged in sheets, spindle cells show fascicular growth. The enlarged, relatively monomorphic round, oval, or elongated nuclei are vesicular with prominent nucleoli. The cytoplasm is scant or moderate, more or less intense eosinophilic, and can be rhabdoid in the epithelioid population. Round-cell morphology and uncommonly pleomorphism and hyperchromasia are reported. Real rhabdomyoblasts are not always present. There is a variable, sometimes prominent stromal reaction with sclerosing/hyalinized areas. Immunohistochemically, tumors were all positive with desmin and MYOD1 and to a much lesser degree with myogenin. ALK seems to be heterogeneously expressed in a large subset of cases, and broad-spectrum keratins are positive in almost all cases. S100 can be expressed without concomitant positivity for SOX10 [26,172,174,175]. Differential diagnoses are listed in Table 13.

Table 13. Differential diagnoses of epithelioid and spindle cell rhabdomyosarcoma.

\begin{tabular}{|c|c|c|c|}
\hline Entity & Morphology & IHC & $\begin{array}{l}\text { Common Genetic } \\
\text { Alterations }\end{array}$ \\
\hline $\begin{array}{l}\text { Inflammatory } \\
\text { myofibroblastic tumor }\end{array}$ & $\begin{array}{l}\text { Fascicular pattern (variable); } \\
\text { plump-spindle cells with } \\
\text { vesicular nuclei and small } \\
\text { nucleoli and amphophilic } \\
\text { cytoplasm; } \\
\text { oedematous-myxoid-fibrous } \\
\text { stroma; and mixed } \\
\text { inflammatory infiltrate }\end{array}$ & $\begin{array}{l}\text { SMA, calponin, desmin, } \\
\text { keratin (focal), ALK, } \\
\text { and ROS1 }\end{array}$ & $\begin{array}{c}A L K \text { rearrangements (various } \\
\text { fusion partners); } R O S 1, \\
N T R K 3, R E T \text {, or } P D G F R B \\
\text { rearrangements }\end{array}$ \\
\hline Carcinoma & $\begin{array}{c}\text { Sheets/nests/trabecules; } \\
\text { round-oval-epithelioid cells } \\
\text { with variable cytoplasm and } \\
\text { nuclear atypia }\end{array}$ & $\begin{array}{c}\text { Pankeratins, lineage-specific } \\
\text { markers (depending on site } \\
\text { of origine) }\end{array}$ & $\begin{array}{c}\text { Diverse (depending on site } \\
\text { of origin) }\end{array}$ \\
\hline Myoepithelial carcinoma & $\begin{array}{l}\text { Solid sheets / nests of variable } \\
\text { myoepithelial cells (epitheloid, } \\
\text { spindled, plasmocytoid, } \\
\text { rhabdoid, and clear) with high } \\
\text { nuclear grade or } \\
\text { undifferentiated round-cell } \\
\text { morphology; necrosis; and } \\
\text { high mitotic count }\end{array}$ & $\begin{array}{l}\text { Pankeratins, EMA, S100, } \\
\text { SOX10, GFAP, P63, SMA, } \\
\text { calponin, desmin (focal); and } \\
\text { INI1 loss (subset) }\end{array}$ & $\begin{array}{l}\text { EWSR1 rearrangements } \\
\text { (various fusion partners); } \\
\text { PLAG1 rearrangements } \\
\text { (mixed tumors) }\end{array}$ \\
\hline EWSR1-PATZ1 sarcoma & $\begin{array}{l}\text { Diverse morphology: } \\
\text { round-spindle cells; } \\
\text { fibrous stroma }\end{array}$ & $\begin{array}{c}\text { Co-expression of } \\
\text { myogenic markers } \\
\text { (desmin/myogenin/MyoD1) } \\
\text { and neurogenic markers } \\
\text { (S100/SOX10/MITF/GFAP) }\end{array}$ & EWSR1-PATZ1 \\
\hline $\begin{array}{l}\text { Dedifferentiated } \\
\text { chondrosarcoma }\end{array}$ & $\begin{array}{c}\text { Conventional } \\
\text { chondrosarcoma with abrupt } \\
\text { transition to a high-grade } \\
\text { non-cartilaginous sarcoma } \\
\text { (undifferentiated sarcoma, } \\
\text { osteosarcoma, angiosarcoma, } \\
\text { leiomyosarcoma, and } \\
\text { rhabdomyosarcoma) }\end{array}$ & $\begin{array}{l}\text { Diverse (according to line of } \\
\text { differentiation); loss of } \\
\text { H3K27me3, MDM2 } \\
\text { overexpression, p53 } \\
\text { overexpression, and PDL1 }\end{array}$ & $\begin{array}{c}\text { Complex karyotype; IDH1/2, } \\
\text { TP53 mutations }\end{array}$ \\
\hline
\end{tabular}


Table 13. Cont.

\begin{tabular}{|c|c|c|c|}
\hline Entity & Morphology & IHC & $\begin{array}{l}\text { Common Genetic } \\
\text { Alterations }\end{array}$ \\
\hline $\begin{array}{l}\text { Pseudomyogenic (epitheloid } \\
\text { sarcoma-like) } \\
\text { hemangioendothelioma }\end{array}$ & $\begin{array}{c}\text { Multiple discontinuous } \\
\text { nodules; possibly } \\
\text { involvement of different } \\
\text { tissue planes; sheets/fascicles } \\
\text { of plump-spindle-epithelioid } \\
\text { cells with abundant, brightly } \\
\text { eosinophilic cytoplasm; } \\
\text { vesicular nuclei with small } \\
\text { nucleoli; mild nuclear atypia; } \\
\text { not obvious vascular; and } \\
\text { prominent stromal } \\
\text { neutrophils }(50 \%)\end{array}$ & $\begin{array}{l}\text { Keratins (AE1/ AE3 but not } \\
\text { MNF116), FLI, ERG, CD31 } \\
(50 \%), \text { SMA (focal), and FOSB }\end{array}$ & SERPINE1/ACTB-FOSB \\
\hline $\begin{array}{l}\text { Rhabdomyosarcoma } \\
\text { (spindle cell) }\end{array}$ & $\begin{array}{l}\text { Cellular fascicles with } \\
\text { intersecting/herringbone } \\
\text { pattern; atypical uniform } \\
\text { spindle cells with pale } \\
\text { eosinophilic cytoplasm; } \\
\text { primitive round cells may be } \\
\text { present; and tadpole/strap } \\
\text { cells (sometimes) }\end{array}$ & $\begin{array}{l}\text { Desmin, MyoD1 (focal or } \\
\text { diffuse), myogenin (focal) }\end{array}$ & $\begin{array}{l}\text { SRF/VGLL2/TEAD1-NCOA2, } \\
\text { VGLL2-CITED2 (congenital } \\
\text { spindle cell RMS); and } \\
\text { MYOD1 mutation }\end{array}$ \\
\hline Leiomyosarcoma & $\begin{array}{c}\text { Intersecting fascicles of } \\
\text { smooth muscle cells; } \\
\text { blunt-ended, cigar-shaped } \\
\text { nuclei; variable atypia and } \\
\text { pleomorphism (depending on } \\
\text { grade); eosinophilic } \\
\text { cytoplasm; mitoses; necrosis }\end{array}$ & SMA, desmin, and caldesmon & $\begin{array}{l}\text { Extensive genomic instability } \\
\text { (leiomyosarcoma); diverse } \\
\text { gene involvement with p53 } \\
\text { mutations; deleterious ATRX } \\
\text { alterations; ALK } \\
\text { rearrangement (small subset); } \\
\text { and NF1 mutations (subset of } \\
\text { inflammatory } \\
\text { leiomyosarcoma); }\end{array}$ \\
\hline Melanoma & $\begin{array}{c}\text { Diverse growth patterns; } \\
\text { large, atypical } \\
\text { spindle-epithelioid-bizarre } \\
\text { cells with vesicular nuclei and } \\
\text { prominent, eosinophilic } \\
\text { nucleoli; nuclear } \\
\text { pseudo-inclusions; abundant } \\
\text { eosinophilic-clear cytoplasm; } \\
\text { and melanin pigment }\end{array}$ & $\begin{array}{l}\text { S100, SOX10, Melan-A, } \\
\text { HMB45, and MITF }\end{array}$ & $\begin{array}{c}\text { Diverse: ARID2, BAP1, BRAF, } \\
\text { GNAQ, HRAS, KIT, NF1, } \\
\text { NRAS, and PTEN mutations; } \\
\text { chromosomal gains/losses }\end{array}$ \\
\hline $\begin{array}{l}\text { Malignant peripheral nerve } \\
\text { sheath tumor }\end{array}$ & $\begin{array}{l}\text { Fascicles of spindle cells with } \\
\text { perivascular accentuation and } \\
\text { alternating cellularity; } \\
\text { staghorn vessels; necrosis; and } \\
\text { heterologous differentiation }\end{array}$ & $\begin{array}{c}\text { S100, SOX10 (focal), and loss } \\
\text { of H3K } 27 \mathrm{me} 3\end{array}$ & $\begin{array}{l}\text { Inactivating mutations of } N F 1 \text {, } \\
C D K N 2 A / B, E E D \text {, and } S U Z 2\end{array}$ \\
\hline
\end{tabular}

Most of the tumors behave extremely aggressively, with a reported median survival of 8 months $[26,172,173]$. However, few patients with local disease and long-term follow-up showed no evidence of disease after treatment, with the mandible being a site of favorable prognosis [172,174-176].

\section{Retroperitoneal Leiomyoma}

The first cytogenetic analyzed retroperitoneal leiomyoma harbored at(10;17)(q22;q21) translocation resulting in a KAT6B-KANSL1 fusion gene, and the second case was identified with a $\mathrm{t}(9 ; 22)(\mathrm{q} 33 ; \mathrm{q} 12)$ leading to an EWSR1-PBX3 chimeric transcript. Both lesions occurred in woman 45 and 26 years old and showed a usual leiomyoma morphology, with 
leiomyocytes arranged in long fascicles and a classical immunoprofile with expression of smooth muscle markers. It is obvious that molecular heterogeneity may exist in these tumors $[177,178]$.

\section{Simple (Unicameral) Bone Cyst (SBC)}

SBC was initially reported by Rudolf Virchow in 1876 [179-181]. It is a benign intramedullary cystic lesion involving the long bones in skeletally immature individuals. Boys are twice as more affected than girls. The reported peak is between the ages of 3 and 14 years. It commonly arises in the proximal humerus or proximal femur and less frequently in other long bones. Symptoms can be pain and swelling. A unilocular expansile cyst showing double-density fluid levels is radiologically characteristic [5,179,180,182].

Macroscopically, an often-fragmented thin fibrous membrane representing the cyst wall possibly with thickening and hemorrhage after trauma is seen (fracture). The fibrous pseudocystic structure is also microscopically obvious showing focal fibrin-like collagen with calcification and ossification. There is no true lining (Figure 15). Myofibroblastic cells and osteoclasts are not as prominent as typically seen in aneurysmal bone cyst (ABC), which is a differential diagnosis. Secondary changes as hemorrhage with resorption with chronic inflammation can be found after fracture. This can camouflage the classical microscopical features $[5,179,180,182]$. In 2002, the translocation $(16 ; 20)(p 11.2 ; q 13)$ was identified as the sole cytogenetic abnormality in a SBC case [183]. Recently, the corresponding FUS1-NFATC2 or alternatively EWSR1-NFATC2 fusion have been demonstrated in a subset of cases proving that SBC is a neoplasm [5,180,182] (WHO, Pizem et al., 2020, Hung et al., 2021).

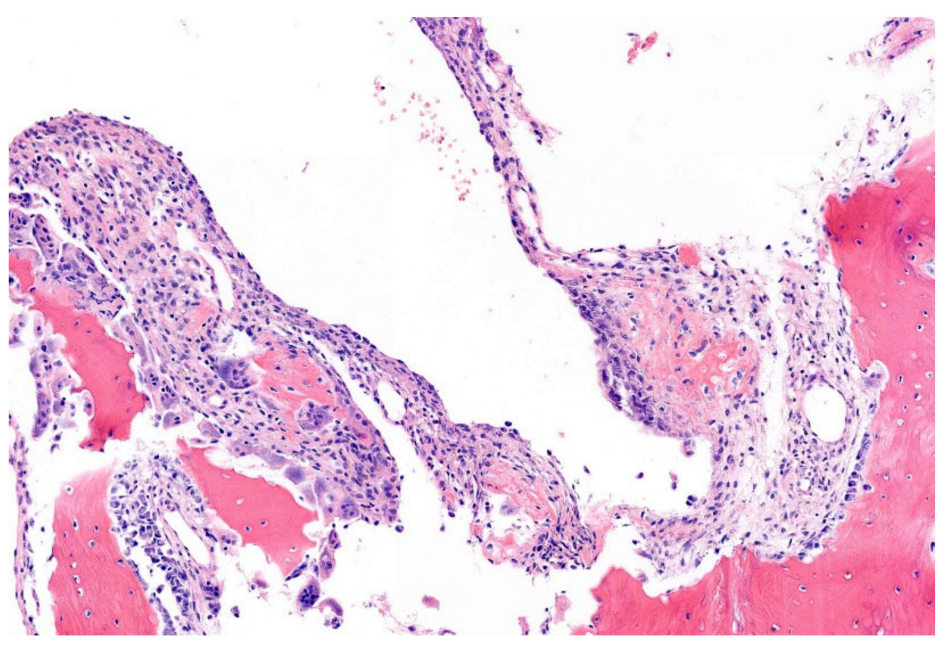

Figure 15. Pseudocystic space of a simple bone cysts lined by myofibroblastic cells. There is primitive osteoid. The preexistent bone shows resorption (HE; $20 \times$ magnification).

Besides $\mathrm{ABC}$, other differential diagnoses are cystic fibrous dysplasia, intraosseous ganglion, or lipoma (Table 14) $[5,180]$.

Table 14. Differential diagnoses of simple (unicameral) bone cyst.

\begin{tabular}{ccc}
\hline Diagnosis & Morphology & Common Genetic Alterations \\
\hline Fibrous dysplasia & $\begin{array}{l}\text { Irregular, curvilinear trabeculae of woven (or rarely lamellar) } \\
\text { bone without osteoblast rimming; inconspicuous osteoblasts; } \\
\text { sharpey fibers; and osteoclasts bland fibroblastic stroma }\end{array}$ & GNAS mutations (50-70\%) \\
\hline Intraosseous ganglion & Cavity without lining; filled with mucoid viscous material & None (probably degenerative) \\
\hline Lipoma & Nodules of mature adipose tissue, often fibrotic & Unknown \\
\hline
\end{tabular}


Conservative and surgical treatment are discussed in the literature. The recurrence rate is low but fractures are a known complication $[5,179,180]$.

\section{Hemangioma of Bone with an EWSR1-NFATC1 Fusion}

In 1982, Mulliken and Glowacki separated vascular anomalies into hemangiomas and vascular malformations based on their clinicopathological appearance and biological background $[184,185]$. This was the base for the classification of the International Society for the Study of Vascular Anomalies (ISSVA) [186]. Vascular tumors arise by clonal cellular proliferation of vessels showing a disproportionate growth. In contrast, vascular malformations originate in utero as a result of mosaic mutations leading to erroneous development of vessels with proportionate growth [187].

Hemangiomas of the bone are relatively common and often incidental findings. They can be found at any age and arise often multifocal. The spine is the predilection site followed by the craniofacial bones. Radiologically, well-demarcated lucent lesions with coarse primary trabeculations are visible. When symptomatic, surgical intervention can be necessary and tissue will be obtained [5].

Macroscopically, the lesional tissue, often piecemeal, is soft and hemorrhagic with some bony fragments.

Microscopy is variable, showing thin and thick-walled vessels of different caliber. The endothelial lining is not remarkable [5]. A stromal reaction can be prominent. A vascular malformation can be difficult to differentiate (Figure 16).

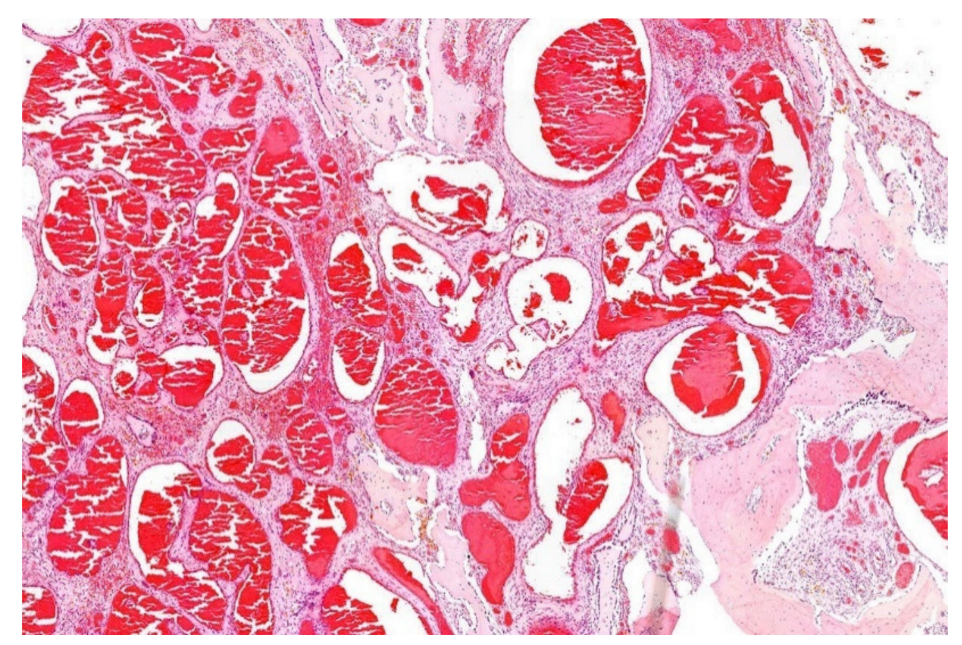

Figure 16. Hemangioma of bone consisting of cavernous blood-filled vessels. Note the surrounding cellular matrix and remodeling of the preexisting bone (HE; $20 \times$ magnification).

Recently, a multifocal hemangioma has been described located in the occipital bone and clavicle showing at $\mathrm{t}(18 ; 22)(\mathrm{q} 23 ; \mathrm{q} 12)$ with an EWSR1-NFATC1 fusion chimera [188].

Comparable lesions were found with EWSR1-NFATC1 or EWSR1-NFATC2 (own observation). Therefore, it seems to be a recurrent finding.

Prognosis is excellent $[5,188]$.

\section{Conclusions}

Several malignant and benign tumors harbor an EWSR1 rearrangement due to the central role of EWSR1 in different cell processes and vulnerability of the gene as consequence of frequent transcription. It was the first described fusion gene in sarcomas, and during the last decade(s) its promiscuous character has been shown by involvement in a variety of tumors. The recently described polyphenotypic sarcomas, which seem to be different entities with aggressive behavior, are interesting in this context. Whether they could be treated like Ewing sarcoma or require a more tailored approach is paramount to investigate. 
Another intriguing point is that the same fusion partners are present in benign and malignant tumors, arguing that secondary genetic and epigenetic changes are mandatory to regulate and activate the required oncogenic pathways.

Author Contributions: Conceptualization, U.F.; writing-original draft preparation, U.F., L.S.H.-J.; writing-review and editing, U.F., L.S.H.-J., M.M.v.N., V.S., B.B.J.T., D.C., J.M.v.G.; visualization, U.F., L.S.H.-J., J.M.v.G. All authors have read and agreed to the published version of the manuscript.

Funding: This research received no external funding.

Institutional Review Board Statement: Not applicable.

Informed Consent Statement: Not applicable.

Data Availability Statement: Not applicable.

Conflicts of Interest: The authors declare no conflict of interest.

\section{References}

1. Delattre, O.; Zucman, J.; Plougastel, B.; Desmaze, C.; Melot, T.; Peter, M.; Kovar, H.; Joubert, I.; de Jong, P.; Rouleau, G.; et al. Gene fusion with an ETS DNA-binding domain caused by chromosome translocation in human tumours. Nature 1992, 359, 162-165. [CrossRef] [PubMed]

2. Lee, J.; Nguyen, P.T.; Shim, H.S.; Hyeon, S.J.; Im, H.; Choi, M.H.; Chung, S.; Kowall, N.W.; Lee, S.B.; Ryu, H. EWSR1, a multifunctional protein, regulates cellular function and aging via genetic and epigenetic pathways. Biochim. Biophys. Acta Mol. Basis Dis 2019, 1865, 1938-1945. [CrossRef]

3. Bertolotti, A.; Bell, B.; Tora, L. The N-terminal domain of human TAFII68 displays transactivation and oncogenic properties. Oncogene 1999, 18, 8000-8010. [CrossRef]

4. Lindén, M.; Thomsen, C.; Grundevik, P.; Jonasson, E.; Andersson, D.; Runnberg, R.; Dolatabadi, S.; Vannas, C.; Luna Santamaría, M.; Fagman, H.; et al. FET family fusion oncoproteins target the SWI/SNF chromatin remodeling complex. EMBO Rep. 2019, 20. [CrossRef] [PubMed]

5. W.H.O. Classification of Soft Tissue and Bone Tumours; International Agency for Research on Cancer: Lyon, France, 2020.

6. Folpe, A.L.; Goldblum, J.R.; Rubin, B.P.; Shehata, B.M.; Liu, W.; Dei Tos, A.P.; Weiss, S.W. Morphologic and immunophenotypic diversity in Ewing family tumors: A study of 66 genetically confirmed cases. Am. J. Surg. Pathol. 2005, 29, 1025-1033. [CrossRef] [PubMed]

7. Stout, A.P. A tumor of ulnar nerve. Proc. NY Pathol. Soc. 1918, 18, 2-12. (In Japanese)

8. Ewing, J. Classics in oncology. Diffuse endothelioma of bone. James Ewing. Proceedings of the New York Pathological Society, 1921. CA Cancer J. Clin. 1972, 22, 95-98. [CrossRef]

9. Seidal, T.; Mark, J.; Hagmar, B.; Angervall, L. Alveolar rhabdomyosarcoma: A cytogenetic and correlated cytological and histological study. Acta Pathol. Microbiol. Immunol. Scand. A 1982, 90, 345-354. [CrossRef]

10. Aurias, A.; Rimbaut, C.; Buffe, D.; Dubousset, J.; Mazabraud, A. Translocation of chromosome 22 in Ewing's sarcoma. C R Seances Acad Sci. III 1983, 296, 1105-1107.

11. Turc-Carel, C. Chromosomal translocations in Ewing's sarcoma. N. Engl. J. Med. 1983, 309, 496-498.

12. Czerniak, B.U. Dorfman and Czerniak's Bone Tumors; Elsevier Health Sciences: Houston, TX, USA, 2015.

13. Miettinen, M.U. Modern Soft Tissue Pathology: Tumors and Non-Neoplastic Conditions; Cambridge University Press: Cambridge, UK, 2010.

14. Rooper, L.M.; Bishop, J.A. Soft Tissue Special Issue: Adamantinoma-Like Ewing Sarcoma of the Head and Neck: A Practical Review of a Challenging Emerging Entity. Head Neck Pathol. 2020, 14, 59-69. [CrossRef] [PubMed]

15. Yoshida, A.; Sekine, S.; Tsuta, K.; Fukayama, M.; Furuta, K.; Tsuda, H. NKX2.2 is a useful immunohistochemical marker for Ewing sarcoma. Am. J. Surg. Pathol. 2012, 36, 993-999. [CrossRef] [PubMed]

16. Shibuya, R.; Matsuyama, A.; Nakamoto, M.; Shiba, E.; Kasai, T.; Hisaoka, M. The combination of CD99 and NKX2.2, a transcriptional target of EWSR1-FLI1, is highly specific for the diagnosis of Ewing sarcoma. Virchows Arch. 2014, 465, 599-605. [CrossRef] [PubMed]

17. Hung, Y.P.; Fletcher, C.D.; Hornick, J.L. Evaluation of NKX2-2 expression in round cell sarcomas and other tumors with EWSR1 rearrangement: Imperfect specificity for Ewing sarcoma. Mod. Pathol. 2016, 29, 370-380. [CrossRef]

18. Russell-Goldman, E.; Hornick, J.L.; Qian, X.; Jo, V.Y. NKX2.2 immunohistochemistry in the distinction of Ewing sarcoma from cytomorphologic mimics: Diagnostic utility and pitfalls. Cancer Cytopathol. 2018, 126, 942-949. [CrossRef]

19. Smith, R.; Owen, L.A.; Trem, D.J.; Wong, J.S.; Whangbo, J.S.; Golub, T.R.; Lessnick, S.L. Expression profiling of EWS/FLI identifies NKX2.2 as a critical target gene in Ewing's sarcoma. Cancer Cell 2006, 9, 405-416. [CrossRef]

20. Barisella, M.; Collini, P.; Orsenigo, M.; Aiello, A.; Paties, C.T.; Dileo, P.; Pilotti, S. Unusual myogenic and melanocytic differentiation of soft tissue pPNETs: An immunohistochemical and molecular study of 3 cases. Am. J. Surg. Pathol. 2010, 34, 1002-1006. [CrossRef] 
21. Thway, K.; Fisher, C. Mesenchymal Tumors with EWSR1 Gene Rearrangements. Surg. Pathol. Clin. 2019, 12, 165-190. [CrossRef]

22. Szuhai, K.; Ijszenga, M.; de Jong, D.; Karseladze, A.; Tanke, H.J.; Hogendoorn, P.C. The NFATc2 gene is involved in a novel cloned translocation in a Ewing sarcoma variant that couples its function in immunology to oncology. Clin. Cancer Res. 2009, 15, 2259-2268. [CrossRef]

23. Koelsche, C.; Kriegsmann, M.; Kommoss, F.K.F.; Stichel, D.; Kriegsmann, K.; Vokuhl, C.; Grünewald, T.G.P.; Romero-Pérez, L.; Kirchner, T.; de Alava, E.; et al. DNA methylation profiling distinguishes Ewing-like sarcoma with EWSR1-NFATc2 fusion from Ewing sarcoma. J. Cancer Res. Clin. Oncol. 2019, 145, 1273-1281. [CrossRef]

24. Le Loarer, F.; Pissaloux, D.; Coindre, J.M.; Tirode, F.; Vince, D.R. Update on Families of Round Cell Sarcomas Other than Classical Ewing Sarcomas. Surg. Pathol. Clin. 2017, 10, 587-620. [CrossRef]

25. Bode-Lesniewska, B.; Fritz, C.; Exner, G.U.; Wagner, U.; Fuchs, B. EWSR1-NFATC2 and FUS-NFATC2 Gene Fusion-Associated Mesenchymal Tumors: Clinicopathologic Correlation and Literature Review. Sarcoma 2019, 2019, 9386390. [CrossRef] [PubMed]

26. Watson, S.; Perrin, V.; Guillemot, D.; Reynaud, S.; Coindre, J.M.; Karanian, M.; Guinebretière, J.M.; Freneaux, P.; Le Loarer, F.; Bouvet, M.; et al. Transcriptomic definition of molecular subgroups of small round cell sarcomas. J. Pathol. 2018, 245, 29-40. [CrossRef]

27. Perret, R.; Escuriol, J.; Velasco, V.; Mayeur, L.; Soubeyran, I.; Delfour, C.; Aubert, S.; Polivka, M.; Karanian, M.; Meurgey, A.; et al. Correction: NFATc2-rearranged sarcomas: Clinicopathologic, molecular, and cytogenetic study of 7 cases with evidence of AGGRECAN as a novel diagnostic marker. Mod. Pathol. 2020, 33, 2087. [CrossRef] [PubMed]

28. Mastrangelo, T.; Modena, P.; Tornielli, S.; Bullrich, F.; Testi, M.A.; Mezzelani, A.; Radice, P.; Azzarelli, A.; Pilotti, S.; Croce, C.M.; et al. A novel zinc finger gene is fused to EWS in small round cell tumor. Oncogene 2000, 19, 3799-3804. [CrossRef]

29. Michal, M.; Rubin, B.P.; Agaimy, A.; Kosemehmetoglu, K.; Rudzinski, E.R.; Linos, K.; John, I.; Gatalica, Z.; Davis, J.L.; Liu, Y.J.; et al. EWSR1-PATZ1-rearranged sarcoma: A report of nine cases of spindle and round cell neoplasms with predilection for thoracoabdominal soft tissues and frequent expression of neural and skeletal muscle markers. Mod. Pathol. 2021, 34, 770-785. [CrossRef]

30. Benini, S.; Gamberi, G.; Cocchi, S.; Righi, A.; Frisoni, T.; Longhi, A.; Gambarotti, M. Identification of a novel fusion transcript EWSR1-VEZF1 by anchored multiplex PCR in malignant peripheral nerve sheath tumor. Pathol. Res. Pract. 2020, 216, 152760. [CrossRef]

31. Tsuda, Y.; Zhang, L.; Meyers, P.; Tap, W.D.; Healey, J.H.; Antonescu, C.R. The clinical heterogeneity of round cell sarcomas with EWSR1/FUS gene fusions: Impact of gene fusion type on clinical features and outcome. Genes Chromosomes Cancer 2020, 59, 525-534. [CrossRef]

32. Siegfried, A.; Rousseau, A.; Maurage, C.A.; Pericart, S.; Nicaise, Y.; Escudie, F.; Grand, D.; Delrieu, A.; Gomez-Brouchet, A.; Le Guellec, S.; et al. EWSR1-PATZ1 gene fusion may define a new glioneuronal tumor entity. Brain Pathol. 2019, 29, 53-62. [CrossRef]

33. Bridge, J.A.; Sumegi, J.; Druta, M.; Bui, M.M.; Henderson-Jackson, E.; Linos, K.; Baker, M.; Walko, C.M.; Millis, S.; Brohl, A.S. Clinical, pathological, and genomic features of EWSR1-PATZ1 fusion sarcoma. Mod. Pathol. 2019, 32, 1593-1604. [CrossRef] [PubMed]

34. Chougule, A.; Taylor, M.S.; Nardi, V.; Chebib, I.; Cote, G.M.; Choy, E.; Nielsen, G.P.; Deshpande, V. Spindle and Round Cell Sarcoma With EWSR1-PATZ1 Gene Fusion: A Sarcoma With Polyphenotypic Differentiation. Am. J. Surg. Pathol. 2019, 43, 220-228. [CrossRef] [PubMed]

35. Yau, D.T.W.; Wong, S.; Chow, C.; To, K.F. Round Cell Sarcoma with EWSR1-PATZ1 Fusion in the Face of a Five-Year-Old Boy: Report of a Case with Unusual Histologic Features. Head Neck Pathol. 2021. [CrossRef] [PubMed]

36. Sumegi, J.; Nishio, J.; Nelson, M.; Frayer, R.W.; Perry, D.; Bridge, J.A. A novel t(4;22)(q31;q12) produces an EWSR1-SMARCA5 fusion in extraskeletal Ewing sarcoma/primitive neuroectodermal tumor. Mod. Pathol. 2011, 24, 333-342. [CrossRef] [PubMed]

37. Sawyer, J.R.; Tryka, A.F.; Lewis, J.M. A novel reciprocal chromosome translocation $\mathrm{t}(11 ; 22)(\mathrm{p} 13 ; \mathrm{q} 12)$ in an intraabdominal desmoplastic small round-cell tumor. Am. J. Surg. Pathol. 1992, 16, 411-416. [CrossRef]

38. Gerald, W.L.; Miller, H.K.; Battifora, H.; Miettinen, M.; Silva, E.G.; Rosai, J. Intra-abdominal desmoplastic small round-cell tumor. Report of 19 cases of a distinctive type of high-grade polyphenotypic malignancy affecting young individuals. Am. J. Surg. Pathol. 1991, 15, 499-513. [CrossRef]

39. Gerald, W.L.; Rosai, J.; Ladanyi, M. Characterization of the genomic breakpoint and chimeric transcripts in the EWS-WT1 gene fusion of desmoplastic small round cell tumor. Proc. Natl. Acad. Sci. USA 1995, 92, 1028-1032. [CrossRef]

40. Ladanyi, M.; Gerald, W. Fusion of the EWS and WT1 genes in the desmoplastic small round cell tumor. Cancer Res. 1994, 54, 2837-2840.

41. Lae, M.E.; Roche, P.C.; Jin, L.; Lloyd, R.V.; Nascimento, A.G. Desmoplastic small round cell tumor: A clinicopathologic, immunohistochemical, and molecular study of 32 tumors. Am. J. Surg. Pathol. 2002, 26, 823-835. [CrossRef]

42. Antonescu, C.R.; Gerald, W.L.; Magid, M.S.; Ladanyi, M. Molecular variants of the EWS-WT1 gene fusion in desmoplastic small round cell tumor. Diagn. Mol. Pathol. 1998, 7, 24-28. [CrossRef]

43. Gerald, W.L.; Ladanyi, M.; de Alava, E.; Cuatrecasas, M.; Kushner, B.H.; LaQuaglia, M.P.; Rosai, J. Clinical, pathologic, and molecular spectrum of tumors associated with $\mathrm{t}(11 ; 22)(\mathrm{p} 13 ; \mathrm{q} 12)$ : Desmoplastic small round-cell tumor and its variants. J. Clin. Oncol. 1998, 16, 3028-3036. [CrossRef]

44. Mora, J.; Modak, S.; Cheung, N.K.; Meyers, P.; de Alava, E.; Kushner, B.; Magnan, H.; Tirado, O.M.; Laquaglia, M.; Ladanyi, M.; et al. Desmoplastic small round cell tumor 20 years after its discovery. Future Oncol. 2015, 11, 1071-1081. [CrossRef] 
45. Lee, J.C.; Villanueva-Meyer, J.E.; Ferris, S.P.; Cham, E.M.; Zucker, J.; Cooney, T.; Gilani, A.; Kleinschmidt-DeMasters, B.K.; Trembath, D.; Mafra, M.; et al. Clinicopathologic and molecular features of intracranial desmoplastic small round cell tumors. Brain Pathol. 2020, 30, 213-225. [CrossRef] [PubMed]

46. Ordóñez, N.G. Desmoplastic small round cell tumor: II: An ultrastructural and immunohistochemical study with emphasis on new immunohistochemical markers. Am. J. Surg. Pathol. 1998, 22, 1314-1327. [CrossRef] [PubMed]

47. Barnoud, R.; Delattre, O.; Péoc'h, M.; Pasquier, D.; Plantaz, D.; Leroux, D.; Pasquier, B. Desmoplastic small round cell tumor: RT-PCR analysis and immunohistochemical detection of the Wilm's tumor gene WT1. Pathol. Res. Pract. 1998, 194, 693-700. [CrossRef]

48. La Starza, R.; Barba, G.; Nofrini, V.; Pierini, T.; Pierini, V.; Marcomigni, L.; Perruccio, K.; Matteucci, C.; Storlazzi, C.T.; Daniele, G.; et al. Multiple EWSR1-WT1 and WT1-EWSR1 copies in two cases of desmoplastic round cell tumor. Cancer Genet. 2013, 206, 387-392. [CrossRef] [PubMed]

49. Dufresne, A.; Cassier, P.; Couraud, L.; Marec-Bérard, P.; Meeus, P.; Alberti, L.; Blay, J.Y. Desmoplastic small round cell tumor: Current management and recent findings. Sarcoma 2012, 2012, 714986. [CrossRef] [PubMed]

50. Alaggio, R.; Rosolen, A.; Sartori, F.; Leszl, A.; d'Amore, E.S.; Bisogno, G.; Carli, M.; Cecchetto, G.; Coffin, C.M.; Ninfo, V. Spindle cell tumor with EWS-WT1 transcript and a favorable clinical course: A variant of DSCT, a variant of leiomyosarcoma, or a new entity? Report of 2 pediatric cases. Am. J. Surg. Pathol. 2007, 31, 454-459. [CrossRef]

51. Din, N.U.; Pekmezci, M.; Javed, G.; Horvai, A.E.; Ahmad, Z.; Faheem, M.; Navarro, A.L.; López-Terrada, D.; Perry, A. Low-grade small round cell tumor of the cauda equina with EWSR1-WT1 fusion and indolent clinical course. Hum. Pathol. 2015, 46, 153-158. [CrossRef]

52. Bolen, J.W.; Thorning, D. Benign lipoblastoma and myxoid liposarcoma: A comparative light- and electron-microscopic study. Am. J. Surg. Pathol. 1980, 4, 163-174. [CrossRef]

53. Haniball, J.; Sumathi, V.P.; Kindblom, L.G.; Abudu, A.; Carter, S.R.; Tillman, R.M.; Jeys, L.; Spooner, D.; Peake, D.; Grimer, R.J. Prognostic factors and metastatic patterns in primary myxoid/round-cell liposarcoma. Sarcoma 2011, 2011, 538085. [CrossRef] [PubMed]

54. Bekers, E.M.; Song, W.; Suurmeijer, A.J.; Bonenkamp, J.J.; van der Geest, I.C.; Braam, P.M.; Ploegmakers, M.J.; Desar, I.M.; Tops, B.B.; van Gorp, J.M.; et al. Myxoid liposarcoma of the foot: A study of 8 cases. Ann. Diagn. Pathol. 2016, 25, 37-41. [CrossRef]

55. Limon, J.; Turc-Carel, C.; Dal Cin, P.; Rao, U.; Sandberg, A.A. Recurrent chromosome translocations in liposarcoma. Cancer Genet. Cytogenet. 1986, 22, 93-94. [CrossRef]

56. Panagopoulos, I.; Höglund, M.; Mertens, F.; Mandahl, N.; Mitelman, F.; Aman, P. Fusion of the EWS and CHOP genes in myxoid liposarcoma. Oncogene 1996, 12, 489-494. [CrossRef]

57. Panagopoulos, I.; Mertens, F.; Isaksson, M.; Mandahl, N. A novel FUS/CHOP chimera in myxoid liposarcoma. Biochem. Biophys. Res. Commun. 2000, 279, 838-845. [CrossRef]

58. Tallini, G.; Akerman, M.; Dal Cin, P.; De Wever, I.; Fletcher, C.D.; Mandahl, N.; Mertens, F.; Mitelman, F.; Rosai, J.; Rydholm, A.; et al. Combined morphologic and karyotypic study of 28 myxoid liposarcomas. Implications for a revised morphologic typing, (a report from the CHAMP Group). Am. J. Surg. Pathol. 1996, 20, 1047-1055. [CrossRef] [PubMed]

59. Knight, J.C.; Renwick, P.J.; Dal Cin, P.; Van den Berghe, H.; Fletcher, C.D. Translocation t(12;16)(q13;p11) in myxoid liposarcoma and round cell liposarcoma: Molecular and cytogenetic analysis. Cancer Res. 1995, 55, 24-27. [PubMed]

60. Evans, H.L. Liposarcoma: A study of 55 cases with a reassessment of its classification. Am. J. Surg. Pathol. 1979, 3, 507-523. [CrossRef] [PubMed]

61. Alaggio, R.; Coffin, C.M.; Weiss, S.W.; Bridge, J.A.; Issakov, J.; Oliveira, A.M.; Folpe, A.L. Liposarcomas in young patients: A study of 82 cases occurring in patients younger than 22 years of age. Am. J. Surg. Pathol. 2009, 33, 645-658. [CrossRef] [PubMed]

62. Fritchie, K.J.; Goldblum, J.R.; Tubbs, R.R.; Sun, Y.; Carver, P.; Billings, S.D.; Rubin, B.P. The expanded histologic spectrum of myxoid liposarcoma with an emphasis on newly described patterns: Implications for diagnosis on small biopsy specimens. Am. J. Clin. Pathol. 2012, 137, 229-239. [CrossRef]

63. Dadone, B.; Refae, S.; Lemarié-Delaunay, C.; Bianchini, L.; Pedeutour, F. Molecular cytogenetics of pediatric adipocytic tumors. Cancer Genet. 2015, 208, 469-481. [CrossRef]

64. Dei Tos, A.P. Liposarcomas: Diagnostic pitfalls and new insights. Histopathology 2014, 64, 38-52. [CrossRef] [PubMed]

65. Estourgie, S.H.; Nielsen, G.P.; Ott, M.J. Metastatic patterns of extremity myxoid liposarcoma and their outcome. J. Surg. Oncol. 2002, 80, 89-93. [CrossRef] [PubMed]

66. De Vreeze, R.S.; de Jong, D.; Tielen, I.H.; Ruijter, H.J.; Nederlof, P.M.; Haas, R.L.; van Coevorden, F. Primary retroperitoneal myxoid/round cell liposarcoma is a nonexisting disease: An immunohistochemical and molecular biological analysis. Mod. Pathol. 2009, 22, 223-231. [CrossRef] [PubMed]

67. Scapa, J.V.; Cloutier, J.M.; Raghavan, S.S.; Peters-Schulze, G.; Varma, S.; Charville, G.W. DDIT3 Immunohistochemistry Is a Useful Tool for the Diagnosis of Myxoid Liposarcoma. Am. J. Surg. Pathol. 2021, 45, 230-239. [CrossRef]

68. Baranov, E.; Black, M.A.; Fletcher, C.D.M.; Charville, G.W.; Hornick, J.L. Nuclear expression of DDIT3 distinguishes high-grade myxoid liposarcoma from other round cell sarcomas. Mod. Pathol. 2021. [CrossRef]

69. Vargas, A.C.; Chan, N.L.; Wong, D.D.; Zaborowski, M.; Fuchs, T.L.; Ahadi, M.; Clarkson, A.; Sioson, L.; Sheen, A.; Maclean, F.; et al. DNA damage-inducible transcript 3 immunohistochemistry is highly sensitive for the diagnosis of myxoid liposarcoma but care is required in interpreting the significance of focal expression. Histopathology 2021. [CrossRef] 
70. Lansu, J.; Bovée, J.; Braam, P.; van Boven, H.; Flucke, U.; Bonenkamp, J.J.; Miah, A.B.; Zaidi, S.H.; Thway, K.; Bruland, Ø.S.; et al. Dose Reduction of Preoperative Radiotherapy in Myxoid Liposarcoma: A Nonrandomized Controlled Trial. JAMA Oncol. 2021, 7, e205865. [CrossRef]

71. Mayr, B.; Montminy, M. Transcriptional regulation by the phosphorylation-dependent factor CREB. Nat. Rev. Mol. Cell Biol. 2001, 2, 599-609. [CrossRef]

72. Yoshida, A.; Wakai, S.; Ryo, E.; Miyata, K.; Miyazawa, M.; Yoshida, K.I.; Motoi, T.; Ogawa, C.; Iwata, S.; Kobayashi, E.; et al. Expanding the Phenotypic Spectrum of Mesenchymal Tumors Harboring the EWSR1-CREM Fusion. Am. J. Surg. Pathol. 2019, 43, 1622-1630. [CrossRef] [PubMed]

73. Enzinger, F.M. Angiomatoid malignant fibrous histiocytoma: A distinct fibrohistiocytic tumor of children and young adults simulating a vascular neoplasm. Cancer 1979, 44, 2147-2157. [CrossRef]

74. Waters, B.L.; Panagopoulos, I.; Allen, E.F. Genetic characterization of angiomatoid fibrous histiocytoma identifies fusion of the FUS and ATF-1 genes induced by a chromosomal translocation involving bands 12q13 and 16p11. Cancer Genet. Cytogenet. 2000, 121, 109-116. [CrossRef]

75. Antonescu, C.R.; Dal Cin, P.; Nafa, K.; Teot, L.A.; Surti, U.; Fletcher, C.D.; Ladanyi, M. EWSR1-CREB1 is the predominant gene fusion in angiomatoid fibrous histiocytoma. Genes Chromosomes Cancer 2007, 46, 1051-1060. [CrossRef]

76. Tornóczky, T.; Bogner, B.; Krausz, T.; Ottóffy, G.; Szuhai, K. Angiomatoid fibrous histiocytoma: Pleomorphic variant associated with multiplication of EWSR1-CREB1 fusion gene. Pathol. Oncol. Res. 2012, 18, 545-548. [CrossRef] [PubMed]

77. Fanburg-Smith, J.C.; Miettinen, M. Angiomatoid "malignant" fibrous histiocytoma: A clinicopathologic study of 158 cases and further exploration of the myoid phenotype. Hum. Pathol. 1999, 30, 1336-1343. [CrossRef]

78. Thway, K.; Fisher, C. Tumors with EWSR1-CREB1 and EWSR1-ATF1 fusions: The current status. Am. J. Surg. Pathol. 2012, 36, e1-e11. [CrossRef] [PubMed]

79. Fletcher, C.D. Angiomatoid "malignant fibrous histiocytoma": An immunohistochemical study indicative of myoid differentiation. Hum. Pathol. 1991, 22, 563-568. [CrossRef]

80. Chen, G.; Folpe, A.L.; Colby, T.V.; Sittampalam, K.; Patey, M.; Chen, M.G.; Chan, J.K. Angiomatoid fibrous histiocytoma: Unusual sites and unusual morphology. Mod. Pathol. 2011, 24, 1560-1570. [CrossRef] [PubMed]

81. Thway, K.; Nicholson, A.G.; Wallace, W.A.; Al-Nafussi, A.; Pilling, J.; Fisher, C. Endobronchial pulmonary angiomatoid fibrous histiocytoma: Two cases with EWSR1-CREB1 and EWSR1-ATF1 fusions. Am. J. Surg. Pathol. 2012, 36, 883-888. [CrossRef]

82. Thway, K.; Fisher, C. Angiomatoid fibrous histiocytoma: The current status of pathology and genetics. Arch. Pathol. Lab. Med. 2015, 139, 674-682. [CrossRef]

83. Bale, T.A.; Oviedo, A.; Kozakewich, H.; Giannini, C.; Davineni, P.K.; Ligon, K.; Alexandrescu, S. Intracranial myxoid mesenchymal tumors with EWSR1-CREB family gene fusions: Myxoid variant of angiomatoid fibrous histiocytoma or novel entity? Brain Pathol. 2018, 28, 183-191. [CrossRef]

84. Kao, Y.C.; Lan, J.; Tai, H.C.; Li, C.F.; Liu, K.W.; Tsai, J.W.; Fang, F.M.; Yu, S.C.; Huang, H.Y. Angiomatoid fibrous histiocytoma: Clinicopathological and molecular characterisation with emphasis on variant histomorphology. J. Clin. Pathol. 2014, 67, 210-215. [CrossRef] [PubMed]

85. Sloan, E.A.; Chiang, J.; Villanueva-Meyer, J.E.; Alexandrescu, S.; Eschbacher, J.M.; Wang, W.; Mafra, M.; Ud Din, N.; Carr-Boyd, E.; Watson, M.; et al. Intracranial mesenchymal tumor with FET-CREB fusion-A unifying diagnosis for the spectrum of intracranial myxoid mesenchymal tumors and angiomatoid fibrous histiocytoma-like neoplasms. Brain Pathol. 2020, e12918. [CrossRef] [PubMed]

86. Schaefer, I.M.; Fletcher, C.D. Myxoid variant of so-called angiomatoid "malignant fibrous histiocytoma": Clinicopathologic characterization in a series of 21 cases. Am. J. Surg. Pathol. 2014, 38, 816-823. [CrossRef]

87. Thway, K.; Nicholson, A.G.; Lawson, K.; Gonzalez, D.; Rice, A.; Balzer, B.; Swansbury, J.; Min, T.; Thompson, L.; Adu-Poku, K.; et al. Primary pulmonary myxoid sarcoma with EWSR1-CREB1 fusion: A new tumor entity. Am. J. Surg. Pathol. 2011, 35, 1722-1732. [CrossRef]

88. Arbajian, E.; Puls, F.; Antonescu, C.R.; Amary, F.; Sciot, R.; Debiec-Rychter, M.; Sumathi, V.P.; Järås, M.; Magnusson, L.; Nilsson, J.; et al. In-depth Genetic Analysis of Sclerosing Epithelioid Fibrosarcoma Reveals Recurrent Genomic Alterations and Potential Treatment Targets. Clin. Cancer Res. 2017, 23, 7426-7434. [CrossRef]

89. Liu, C.; Liu, Y.; Zhao, Y.; Wei, J.; Ma, Y.; Liu, Y.; Huang, J. Primary Intracranial Mesenchymal Tumor with EWSR1-CREM Gene Fusion: A Case Report and Literature Review. World Neurosurg. 2020, 142, 318-324. [CrossRef]

90. Enzinger, F.M. CLEAR-CELL SARCOMA OF TENDONS AND APONEUROSES. AN ANALYSIS OF 21 CASES. Cancer 1965, 18, 1163-1174. [CrossRef]

91. Chung, E.B.; Enzinger, F.M. Malignant melanoma of soft parts. A reassessment of clear cell sarcoma. Am. J. Surg. Pathol. 1983, 7, 405-413. [CrossRef]

92. Bridge, J.A.; Borek, D.A.; Neff, J.R.; Huntrakoon, M. Chromosomal abnormalities in clear cell sarcoma. Implications for histogenesis. Am. J. Clin. Pathol. 1990, 93, 26-31. [CrossRef] [PubMed]

93. Peulvé, P.; Michot, C.; Vannier, J.P.; Tron, P.; Hemet, J. Clear cell sarcoma with t(12;22) (q13-14;q12). Genes Chromosomes Cancer 1991, 3, 400-402. [CrossRef] [PubMed]

94. Fletcher, J.A. Translocation (12;22)(q13-14;q12) is a nonrandom aberration in soft-tissue clear-cell sarcoma. Genes Chromosomes Cancer 1992, 5, 184. [CrossRef] 
95. Zucman, J.; Delattre, O.; Desmaze, C.; Epstein, A.L.; Stenman, G.; Speleman, F.; Fletchers, C.D.; Aurias, A.; Thomas, G. EWS and ATF-1 gene fusion induced by $\mathrm{t}(12 ; 22)$ translocation in malignant melanoma of soft parts. Nat. Genet. 1993, 4, 341-345. [CrossRef]

96. Antonescu, C.R.; Nafa, K.; Segal, N.H.; Dal Cin, P.; Ladanyi, M. EWS-CREB1: A recurrent variant fusion in clear cell sarcomaassociation with gastrointestinal location and absence of melanocytic differentiation. Clin. Cancer Res. 2006, 12, $5356-5362$. [CrossRef]

97. Hisaoka, M.; Ishida, T.; Kuo, T.T.; Matsuyama, A.; Imamura, T.; Nishida, K.; Kuroda, H.; Inayama, Y.; Oshiro, H.; Kobayashi, H.; et al. Clear cell sarcoma of soft tissue: A clinicopathologic, immunohistochemical, and molecular analysis of 33 cases. Am. J. Surg. Pathol. 2008, 32, 452-460. [CrossRef]

98. Coindre, J.M.; Hostein, I.; Terrier, P.; Bouvier-Labit, C.; Collin, F.; Michels, J.J.; Trassard, M.; Marques, B.; Ranchere, D.; Guillou, L. Diagnosis of clear cell sarcoma by real-time reverse transcriptase-polymerase chain reaction analysis of paraffin embedded tissues: Clinicopathologic and molecular analysis of 44 patients from the French sarcoma group. Cancer 2006, 107, 1055-1064. [CrossRef] [PubMed]

99. Clark, M.A.; Johnson, M.B.; Thway, K.; Fisher, C.; Thomas, J.M.; Hayes, A.J. Clear cell sarcoma (melanoma of soft parts): The Royal Marsden Hospital experience. Eur. J. Surg. Oncol. 2008, 34, 800-804. [CrossRef]

100. Wang, W.L.; Mayordomo, E.; Zhang, W.; Hernandez, V.S.; Tuvin, D.; Garcia, L.; Lev, D.C.; Lazar, A.J.; López-Terrada, D. Detection and characterization of EWSR1/ATF1 and EWSR1/CREB1 chimeric transcripts in clear cell sarcoma (melanoma of soft parts). Mod. Pathol. 2009, 22, 1201-1209. [CrossRef]

101. Gonzaga, M.I.; Grant, L.; Curtin, C.; Gootee, J.; Silberstein, P.; Voth, E. The epidemiology and survivorship of clear cell sarcoma: A National Cancer Database (NCDB) review. J. Cancer Res. Clin. Oncol. 2018, 144, 1711-1716. [CrossRef] [PubMed]

102. Lucas, D.R.; Nascimento, A.G.; Sim, F.H. Clear cell sarcoma of soft tissues. Mayo Clinic experience with 35 cases. Am. J. Surg. Pathol. 1992, 16, 1197-1204. [CrossRef] [PubMed]

103. Tirabosco, R.; Lang-Lazdunski, L.; Diss, T.C.; Amary, M.F.; Rodriguez-Justo, M.; Landau, D.; Lorenzi, W.; Flanagan, A.M. Clear cell sarcoma of the mediastinum. Ann. Diagn. Pathol. 2009, 13, 197-200. [CrossRef]

104. Hantschke, M.; Mentzel, T.; Rütten, A.; Palmedo, G.; Calonje, E.; Lazar, A.J.; Kutzner, H. Cutaneous clear cell sarcoma: A clinicopathologic, immunohistochemical, and molecular analysis of 12 cases emphasizing its distinction from dermal melanoma. Am. J. Surg. Pathol. 2010, 34, 216-222. [CrossRef] [PubMed]

105. Krishnan, T.; Menzies, A.M.; Roberts-Thomson, R. Recent advancements in melanoma management. Intern. Med. J. 2021, 51, 327-333. [CrossRef] [PubMed]

106. Ekfors, T.O.; Kujari, H.; Isomäki, M. Clear cell sarcoma of tendons and aponeuroses (malignant melanoma of soft parts) in the duodenum: The first visceral case. Histopathology 1993, 22, 255-259. [CrossRef] [PubMed]

107. Alpers, C.E.; Beckstead, J.H. Malignant neuroendocrine tumor of the jejunum with osteoclast-like giant cells. Enzyme histochemistry distinguishes tumor cells from giant cells. Am. J. Surg. Pathol. 1985, 9, 57-64. [CrossRef] [PubMed]

108. Donner, L.R.; Trompler, R.A.; Dobin, S. Clear cell sarcoma of the ileum: The crucial role of cytogenetics for the diagnosis. Am. J. Surg. Pathol. 1998, 22, 121-124. [CrossRef] [PubMed]

109. Wang, J.; Thway, K. Clear cell sarcoma-like tumor of the gastrointestinal tract: An evolving entity. Arch. Pathol. Lab. Med. 2015, 139, 407-412. [CrossRef]

110. Zambrano, E.; Reyes-Mugica, M.; Franchi, A.; Rosai, J. An osteoclast-rich tumor of the gastrointestinal tract with features resembling clear cell sarcoma of soft parts: Reports of 6 cases of a GIST simulator. Int. J. Surg. Pathol. 2003, 11, 75-81. [CrossRef]

111. Stockman, D.L.; Miettinen, M.; Suster, S.; Spagnolo, D.; Dominguez-Malagon, H.; Hornick, J.L.; Adsay, V.; Chou, P.M.; Amanuel, B.; Vantuinen, P.; et al. Malignant gastrointestinal neuroectodermal tumor: Clinicopathologic, immunohistochemical, ultrastructural, and molecular analysis of 16 cases with a reappraisal of clear cell sarcoma-like tumors of the gastrointestinal tract. Am. J. Surg. Pathol. 2012, 36, 857-868. [CrossRef]

112. Segawa, K.; Sugita, S.; Aoyama, T.; Kubo, T.; Asanuma, H.; Sugawara, T.; Ito, Y.; Tsujiwaki, M.; Fujita, H.; Emori, M.; et al. Detection of specific gene rearrangements by fluorescence in situ hybridization in 16 cases of clear cell sarcoma of soft tissue and 6 cases of clear cell sarcoma-like gastrointestinal tumor. Diagn. Pathol. 2018, 13, 73. [CrossRef]

113. Panagopoulos, I.; Thorsen, J.; Gorunova, L.; Micci, F.; Haugom, L.; Davidson, B.; Heim, S. RNA sequencing identifies fusion of the EWSR1 and YY1 genes in mesothelioma with $\mathrm{t}(14 ; 22)$ (q32;q12). Genes Chromosomes Cancer 2013, 52, 733-740. [CrossRef]

114. Desmeules, P.; Joubert, P.; Zhang, L.; Al-Ahmadie, H.A.; Fletcher, C.D.; Vakiani, E.; Delair, D.F.; Rekhtman, N.; Ladanyi, M.; Travis, W.D.; et al. A Subset of Malignant Mesotheliomas in Young Adults Are Associated With Recurrent EWSR1/FUS-ATF1 Fusions. Am. J. Surg. Pathol. 2017, 41, 980-988. [CrossRef]

115. Argani, P.; Harvey, I.; Nielsen, G.P.; Takano, A.; Suurmeijer, A.J.H.; Voltaggio, L.; Zhang, L.; Sung, Y.S.; Stenzinger, A.; Mechtersheimer, G.; et al. EWSR1/FUS-CREB fusions define a distinctive malignant epithelioid neoplasm with predilection for mesothelial-lined cavities. Mod. Pathol. 2020, 33, 2233-2243. [CrossRef]

116. Stout, A.P.; Gorman, J.G. Mixed tumors of the skin of the salivary gland type. Cancer 1959, 12, 537-543. [CrossRef]

117. De Pinieux, G.; Beabout, J.W.; Unni, K.K.; Sim, F.H. Primary mixed tumor of bone. Skeletal Radiol 2001, 30, 534-536. [CrossRef] [PubMed]

118. Dabska, M. Parachordoma: A new clinicopathologic entity. Cancer 1977, 40, 1586-1592. [CrossRef]

119. Limon, J.; Babińska, M.; Denis, A.; Ryś, J.; Niezabitowski, A. Parachordoma: A rare sarcoma with clonal chromosomal changes. Cancer Genet. Cytogenet. 1998, 102, 78-80. [CrossRef] 
120. Tihy, F.; Scott, P.; Russo, P.; Champagne, M.; Tabet, J.C.; Lemieux, N. Cytogenetic analysis of a parachordoma. Cancer Genet. Cytogenet. 1998, 105, 14-19. [CrossRef]

121. Pauwels, P.; Dal Cin, P.; Roumen, R.; van den Berghe, H.; Sciot, R. Intramuscular mixed tumour with clonal chromosomal changes. Virchows Arch. 1999, 434, 167-171. [CrossRef]

122. Van den Berg, E.; Zorgdrager, H.; Hoekstra, H.J.; Suurmeijer, A.J. Cytogenetics of a soft tissue malignant myoepithelioma. Cancer Genet. Cytogenet. 2004, 151, 87-89. [CrossRef]

123. Hallor, K.H.; Teixeira, M.R.; Fletcher, C.D.; Bizarro, S.; Staaf, J.; Domanski, H.A.; von Steyern, F.V.; Panagopoulos, I.; Mandahl, N.; Mertens, F. Heterogeneous genetic profiles in soft tissue myoepitheliomas. Mod. Pathol. 2008, 21, 1311-1319. [CrossRef]

124. Rekhi, B.; Amare, P.; Gulia, A.; Baisane, C.; Patil, A.; Agarwal, S.; Puri, A.; Jambhekar, N.A. Primary intraosseous myoepithelioma arising in the iliac bone and displaying trisomies of 11, 15, 17 with del (16q) and del (22q11) - A rare case report with review of literature. Pathol. Res. Pract. 2011, 207, 780-785. [CrossRef] [PubMed]

125. Gleason, B.C.; Fletcher, C.D. Myoepithelial carcinoma of soft tissue in children: An aggressive neoplasm analyzed in a series of 29 cases. Am. J. Surg. Pathol. 2007, 31, 1813-1824. [CrossRef] [PubMed]

126. Brandal, P.; Panagopoulos, I.; Bjerkehagen, B.; Gorunova, L.; Skjeldal, S.; Micci, F.; Heim, S. Detection of a t(1;22)(q23;q12) translocation leading to an EWSR1-PBX1 fusion gene in a myoepithelioma. Genes Chromosomes Cancer 2008, 47, 558-564. [CrossRef]

127. Brandal, P.; Panagopoulos, I.; Bjerkehagen, B.; Heim, S. t(19;22)(q13;q12) Translocation leading to the novel fusion gene EWSR1ZNF444 in soft tissue myoepithelial carcinoma. Genes Chromosomes Cancer 2009, 48, 1051-1056. [CrossRef] [PubMed]

128. Antonescu, C.R.; Zhang, L.; Chang, N.E.; Pawel, B.R.; Travis, W.; Katabi, N.; Edelman, M.; Rosenberg, A.E.; Nielsen, G.P.; Dal Cin, P.; et al. EWSR1-POU5F1 fusion in soft tissue myoepithelial tumors. A molecular analysis of sixty-six cases, including soft tissue, bone, and visceral lesions, showing common involvement of the EWSR1 gene. Genes Chromosomes Cancer 2010, 49, 1114-1124. [CrossRef]

129. Flucke, U.; Palmedo, G.; Blankenhorn, N.; Slootweg, P.J.; Kutzner, H.; Mentzel, T. EWSR1 gene rearrangement occurs in a subset of cutaneous myoepithelial tumors: A study of 18 cases. Mod. Pathol. 2011, 24, 1444-1450. [CrossRef]

130. Puls, F.; Arbajian, E.; Magnusson, L.; Douis, H.; Kindblom, L.G.; Mertens, F. Myoepithelioma of bone with a novel FUS-POU5F1 fusion gene. Histopathology 2014, 65, 917-922. [CrossRef] [PubMed]

131. Agaram, N.P.; Chen, H.W.; Zhang, L.; Sung, Y.S.; Panicek, D.; Healey, J.H.; Nielsen, G.P.; Fletcher, C.D.; Antonescu, C.R. EWSR1-PBX3: A novel gene fusion in myoepithelial tumors. Genes Chromosomes Cancer 2015, 54, 63-71. [CrossRef]

132. Huang, S.C.; Chen, H.W.; Zhang, L.; Sung, Y.S.; Agaram, N.P.; Davis, M.; Edelman, M.; Fletcher, C.D.; Antonescu, C.R. Novel FUS-KLF17 and EWSR1-KLF17 fusions in myoepithelial tumors. Genes Chromosomes Cancer 2015, 54, 267-275. [CrossRef]

133. Antonescu, C.R.; Zhang, L.; Shao, S.Y.; Mosquera, J.M.; Weinreb, I.; Katabi, N.; Fletcher, C.D. Frequent PLAG1 gene rearrangements in skin and soft tissue myoepithelioma with ductal differentiation. Genes Chromosomes Cancer 2013, 52, 675-682. [CrossRef]

134. Pairet, G.; Tilman, G.; Sciot, R.; Schubert, T.; Perlepe, V.; Poirel, H.A.; Galant, C. Case Reports in Oncological Medicine Myoepithelioma: A New Rearrangement Involving the LPP Locus in a Case of Multiple Bone and Soft Tissue Lesions. Case Rep. Oncol. Med. 2018, 2018, 3512847. [CrossRef]

135. Hornick, J.L.; Fletcher, C.D. Myoepithelial tumors of soft tissue: A clinicopathologic and immunohistochemical study of 101 cases with evaluation of prognostic parameters. Am. J. Surg. Pathol. 2003, 27, 1183-1196. [CrossRef]

136. Thway, K.; Fisher, C. Myoepithelial tumor of soft tissue: Histology and genetics of an evolving entity. Adv. Anat. Pathol. 2014, 21, 411-419. [CrossRef]

137. Gleason, B.C.; Hornick, J.L. Myoepithelial tumours of skin and soft tissue: An update. Diagn. Histopathol. 2008, 14, 552-562. [CrossRef]

138. Song, W.; Flucke, U.; Suurmeijer, A.J.H. Myoepithelial Tumors of Bone. Surg. Pathol. Clin. 2017, 10, 657-674. [CrossRef]

139. Jo, V.Y.; Antonescu, C.R.; Zhang, L.; Dal Cin, P.; Hornick, J.L.; Fletcher, C.D. Cutaneous syncytial myoepithelioma: Clinicopathologic characterization in a series of 38 cases. Am. J. Surg. Pathol. 2013, 37, 710-718. [CrossRef] [PubMed]

140. Tirabosco, R.; Mangham, D.C.; Rosenberg, A.E.; Vujovic, S.; Bousdras, K.; Pizzolitto, S.; De Maglio, G.; den Bakker, M.A.; Di Francesco, L.; Kalil, R.K.; et al. Brachyury expression in extra-axial skeletal and soft tissue chordomas: A marker that distinguishes chordoma from mixed tumor/myoepithelioma/parachordoma in soft tissue. Am. J. Surg. Pathol. 2008, 32, 572-580. [CrossRef] [PubMed]

141. Guillou, L.; Benhattar, J.; Gengler, C.; Gallagher, G.; Ranchère-Vince, D.; Collin, F.; Terrier, P.; Terrier-Lacombe, M.J.; Leroux, A.; Marquès, B.; et al. Translocation-positive low-grade fibromyxoid sarcoma: Clinicopathologic and molecular analysis of a series expanding the morphologic spectrum and suggesting potential relationship to sclerosing epithelioid fibrosarcoma: A study from the French Sarcoma Group. Am. J. Surg. Pathol. 2007, 31, 1387-1402. [CrossRef] [PubMed]

142. Antonescu, C.R.; Rosenblum, M.K.; Pereira, P.; Nascimento, A.G.; Woodruff, J.M. Sclerosing epithelioid fibrosarcoma: A study of 16 cases and confirmation of a clinicopathologically distinct tumor. Am. J. Surg. Pathol. 2001, 25, 699-709. [CrossRef]

143. Evans, H.L. Low-grade fibromyxoid sarcoma. A report of two metastasizing neoplasms having a deceptively benign appearance. Am. J. Clin. Pathol. 1987, 88, 615-619. [CrossRef] [PubMed]

144. Meis-Kindblom, J.M.; Kindblom, L.G.; Enzinger, F.M. Sclerosing epithelioid fibrosarcoma. A variant of fibrosarcoma simulating carcinoma. Am. J. Surg. Pathol. 1995, 19, 979-993. [CrossRef] 
145. Reid, R.; de Silva, M.V.; Paterson, L.; Ryan, E.; Fisher, C. Low-grade fibromyxoid sarcoma and hyalinizing spindle cell tumor with giant rosettes share a common $\mathrm{t}(7 ; 16)(\mathrm{q} 34 ; \mathrm{p} 11)$ translocation. Am. J. Surg. Pathol. 2003, 27, 1229-1236. [CrossRef]

146. Storlazzi, C.T.; Mertens, F.; Nascimento, A.; Isaksson, M.; Wejde, J.; Brosjo, O.; Mandahl, N.; Panagopoulos, I. Fusion of the FUS and BBF2H7 genes in low grade fibromyxoid sarcoma. Hum. Mol. Genet. 2003, 12, 2349-2358. [CrossRef]

147. Mertens, F.; Fletcher, C.D.; Antonescu, C.R.; Coindre, J.M.; Colecchia, M.; Domanski, H.A.; Downs-Kelly, E.; Fisher, C.; Goldblum, J.R.; Guillou, L.; et al. Clinicopathologic and molecular genetic characterization of low-grade fibromyxoid sarcoma, and cloning of a novel FUS/CREB3L1 fusion gene. Lab. Investig. 2005, 85, 408-415. [CrossRef]

148. Lau, P.P.; Lui, P.C.; Lau, G.T.; Yau, D.T.; Cheung, E.T.; Chan, J.K. EWSR1-CREB3L1 gene fusion: A novel alternative molecular aberration of low-grade fibromyxoid sarcoma. Am. J. Surg. Pathol. 2013, 37, 734-738. [CrossRef]

149. Arbajian, E.; Puls, F.; Magnusson, L.; Thway, K.; Fisher, C.; Sumathi, V.P.; Tayebwa, J.; Nord, K.H.; Kindblom, L.G.; Mertens, F. Recurrent EWSR1-CREB3L1 gene fusions in sclerosing epithelioid fibrosarcoma. Am. J. Surg. Pathol. 2014, 38, 801-808. [CrossRef]

150. Evans, H.L. Low-grade fibromyxoid sarcoma: A clinicopathologic study of 33 cases with long-term follow-up. Am. J. Surg. Pathol. 2011, 35, 1450-1462. [CrossRef] [PubMed]

151. Evans, H.L. Low-grade fibromyxoid sarcoma. A report of 12 cases. Am. J. Surg. Pathol. 1993, 17, 595-600. [CrossRef]

152. Mok, Y.; Pang, Y.H.; Sanjeev, J.S.; Kuick, C.H.; Chang, K.T. Primary Renal Hybrid Low-grade Fibromyxoid Sarcoma-Sclerosing Epithelioid Fibrosarcoma: An Unusual Pediatric Case With EWSR1-CREB3L1 Fusion. Pediatr. Dev. Pathol. 2018, 21, 574-579. [CrossRef] [PubMed]

153. Kosemehmetoglu, K.; Ardic, F.; Kilpatrick, S.E.; Aydingoz, U.; Sumathi, V.P.; Michal, M. Sclerosing epithelioid fibrosarcoma of bone: Morphological, immunophenotypical, and molecular findings of 9 cases. Virchows Arch. 2021, 478, 767-777. [CrossRef] [PubMed]

154. Doyle, L.A.; Möller, E.; Dal Cin, P.; Fletcher, C.D.; Mertens, F.; Hornick, J.L. MUC4 is a highly sensitive and specific marker for low-grade fibromyxoid sarcoma. Am. J. Surg. Pathol. 2011, 35, 733-741. [CrossRef]

155. Doyle, L.A.; Wang, W.L.; Dal Cin, P.; Lopez-Terrada, D.; Mertens, F.; Lazar, A.J.; Fletcher, C.D.; Hornick, J.L. MUC4 is a sensitive and extremely useful marker for sclerosing epithelioid fibrosarcoma: Association with FUS gene rearrangement. Am. J. Surg. Pathol. 2012, 36, 1444-1451. [CrossRef]

156. Stout, A.P.; Verner, E.W. Chondrosarcoma of the extraskeletal soft tissues. Cancer 1953, 6, 581-590. [CrossRef]

157. Enzinger, F.M.; Shiraki, M. Extraskeletal myxoid chondrosarcoma. An analysis of 34 cases. Hum. Pathol. 1972, 3, 421-435. [CrossRef]

158. Labelle, Y.; Zucman, J.; Stenman, G.; Kindblom, L.G.; Knight, J.; Turc-Carel, C.; Dockhorn-Dworniczak, B.; Mandahl, N.; Desmaze, C.; Peter, M.; et al. Oncogenic conversion of a novel orphan nuclear receptor by chromosome translocation. Hum. Mol. Genet. 1995, 4, 2219-2226. [CrossRef] [PubMed]

159. Hinrichs, S.H.; Jaramillo, M.A.; Gumerlock, P.H.; Gardner, M.B.; Lewis, J.P.; Freeman, A.E. Myxoid chondrosarcoma with a translocation involving chromosomes 9 and 22. Cancer Genet. Cytogenet. 1985, 14, 219-226. [CrossRef]

160. Hisaoka, M.; Hashimoto, H. Extraskeletal myxoid chondrosarcoma: Updated clinicopathological and molecular genetic characteristics. Pathol. Int. 2005, 55, 453-463. [CrossRef] [PubMed]

161. Flucke, U.; Tops, B.B.; Verdijk, M.A.; van Cleef, P.J.; van Zwam, P.H.; Slootweg, P.J.; Bovée, J.V.; Riedl, R.G.; Creytens, D.H.; Suurmeijer, A.J.; et al. NR4A3 rearrangement reliably distinguishes between the clinicopathologically overlapping entities myoepithelial carcinoma of soft tissue and cellular extraskeletal myxoid chondrosarcoma. Virchows Arch. 2012, 460, 621-628. [CrossRef] [PubMed]

162. Meis-Kindblom, J.M.; Bergh, P.; Gunterberg, B.; Kindblom, L.G. Extraskeletal myxoid chondrosarcoma: A reappraisal of its morphologic spectrum and prognostic factors based on 117 cases. Am. J. Surg. Pathol. 1999, 23, 636-650. [CrossRef]

163. Hachitanda, Y.; Tsuneyoshi, M.; Daimaru, Y.; Enjoji, M.; Nakagawara, A.; Ikeda, K.; Sueishi, K. Extraskeletal myxoid chondrosarcoma in young children. Cancer 1988, 61, 2521-2526. [CrossRef]

164. Demicco, E.G.; Wang, W.L.; Madewell, J.E.; Huang, D.; Bui, M.M.; Bridge, J.A.; Meis, J.M. Osseous myxochondroid sarcoma: A detailed study of 5 cases of extraskeletal myxoid chondrosarcoma of the bone. Am. J. Surg. Pathol. 2013, 37, 752-762. [CrossRef] [PubMed]

165. Drilon, A.D.; Popat, S.; Bhuchar, G.; D’Adamo, D.R.; Keohan, M.L.; Fisher, C.; Antonescu, C.R.; Singer, S.; Brennan, M.F.; Judson, I.; et al. Extraskeletal myxoid chondrosarcoma: A retrospective review from 2 referral centers emphasizing long-term outcomes with surgery and chemotherapy. Cancer 2008, 113, 3364-3371. [CrossRef]

166. Kao, Y.C.; Flucke, U.; Eijkelenboom, A.; Zhang, L.; Sung, Y.S.; Suurmeijer, A.J.H.; Antonescu, C.R. Novel EWSR1-SMAD3 Gene Fusions in a Group of Acral Fibroblastic Spindle Cell Neoplasms. Am. J. Surg. Pathol. 2018, 42, 522-528. [CrossRef] [PubMed]

167. Michal, M.; Berry, R.S.; Rubin, B.P.; Kilpatrick, S.E.; Agaimy, A.; Kazakov, D.V.; Steiner, P.; Ptakova, N.; Martinek, P.; Hadravsky, L.; et al. EWSR1-SMAD3-rearranged Fibroblastic Tumor: An Emerging Entity in an Increasingly More Complex Group of Fibroblastic/Myofibroblastic Neoplasms. Am. J. Surg. Pathol. 2018, 42, 1325-1333. [CrossRef] [PubMed]

168. Zhao, L.; Sun, M.; Lao, I.W.; Yu, L.; Wang, J. EWSR1-SMAD3 positive fibroblastic tumor. Exp. Mol. Pathol. $2019,110,104291$. [CrossRef]

169. Foot, O.; Hallin, M.; Jones, R.L.; Sumathi, V.P.; Thway, K. EWSR1-SMAD3-Positive Fibroblastic Tumor. Int. J. Surg. Pathol. 2020. [CrossRef] [PubMed] 
170. Habeeb, O.; Korty, K.E.; Azzato, E.M.; Astbury, C.; Farkas, D.H.; Ko, J.S.; Billings, S.D. EWSR1-SMAD3 rearranged fibroblastic tumor: Case series and review. J. Cutan. Pathol. 2021, 48, 255-262. [CrossRef]

171. De Noon, S.; Flanagan, A.M.; Tirabosco, R.; O’Donnell, P.; Amary, F. EWSR1-SMAD3 fibroblastic tumour of bone: Expanding the clinical spectrum. Skelet. Radiol. 2021, 50, 445-450. [CrossRef]

172. Le Loarer, F.; Cleven, A.H.G.; Bouvier, C.; Castex, M.P.; Romagosa, C.; Moreau, A.; Salas, S.; Bonhomme, B.; Gomez-Brouchet, A.; Laurent, C.; et al. A subset of epithelioid and spindle cell rhabdomyosarcomas is associated with TFCP2 fusions and common ALK upregulation. Mod. Pathol. 2020, 33, 404-419. [CrossRef]

173. Dashti, N.K.; Wehrs, R.N.; Thomas, B.C.; Nair, A.; Davila, J.; Buckner, J.C.; Martinez, A.P.; Sukov, W.R.; Halling, K.C.; Howe, B.M.; et al. Spindle cell rhabdomyosarcoma of bone with FUS-TFCP2 fusion: Confirmation of a very recently described rhabdomyosarcoma subtype. Histopathology 2018, 73, 514-520. [CrossRef]

174. Agaram, N.P.; Zhang, L.; Sung, Y.S.; Cavalcanti, M.S.; Torrence, D.; Wexler, L.; Francis, G.; Sommerville, S.; Swanson, D.; Dickson, B.C.; et al. Expanding the Spectrum of Intraosseous Rhabdomyosarcoma: Correlation Between 2 Distinct Gene Fusions and Phenotype. Am. J. Surg. Pathol. 2019, 43, 695-702. [CrossRef] [PubMed]

175. Chrisinger, J.S.A.; Wehrli, B.; Dickson, B.C.; Fasih, S.; Hirbe, A.C.; Shultz, D.B.; Zadeh, G.; Gupta, A.A.; Demicco, E.G. Epithelioid and spindle cell rhabdomyosarcoma with FUS-TFCP2 or EWSR1-TFCP2 fusion: Report of two cases. Virchows Arch. 2020, 477, 725-732. [CrossRef]

176. Tagami, Y.; Sugita, S.; Kubo, T.; Iesato, N.; Emori, M.; Takada, K.; Tsujiwaki, M.; Segawa, K.; Sugawara, T.; Kikuchi, T.; et al. Spindle cell rhabdomyosarcoma in a lumbar vertebra with FUS-TFCP2 fusion. Pathol. Res. Pract. 2019, 215, 152399. [CrossRef] [PubMed]

177. Panagopoulos, I.; Gorunova, L.; Bjerkehagen, B.; Heim, S. Novel KAT6B-KANSL1 fusion gene identified by RNA sequencing in retroperitoneal leiomyoma with $\mathrm{t}(10 ; 17)(\mathrm{q} 22 ; \mathrm{q} 21)$. PLOS ONE 2015, 10, e0117010. [CrossRef] [PubMed]

178. Panagopoulos, I.; Gorunova, L.; Bjerkehagen, B.; Heim, S. Fusion of the genes EWSR1 and PBX3 in retroperitoneal leiomyoma with $\mathrm{t}(9 ; 22)(\mathrm{q} 33 ; \mathrm{q} 12)$. PLoS ONE 2015, 10, e0124288. [CrossRef]

179. Noordin, S.; Allana, S.; Umer, M.; Jamil, M.; Hilal, K.; Uddin, N. Unicameral bone cysts: Current concepts. Ann. Med. Surg. 2018, 34, 43-49. [CrossRef]

180. Hung, Y.P.; Fisch, A.S.; Diaz-Perez, J.A.; Iafrate, A.J.; Lennerz, J.K.; Nardi, V.; Bredella, M.A.; Raskin, K.A.; Lozano-Calderon, S.A.; Rosenberg, A.E.; et al. Identification of EWSR1-NFATC2 fusion in simple bone cysts. Histopathology 2020. [CrossRef]

181. Virchow, R. On the formation of bony cysts. Über die Bildung von Knochencysten 1876, 369-381.

182. Pižem, J.; Šekoranja, D.; Zupan, A.; Boštjančič, E.; Matjašič, A.; Mavčič, B.; Contreras, J.A.; Gazič, B.; Martinčič, D.; Snoj, Ž.; et al. FUS-NFATC2 or EWSR1-NFATC2 Fusions Are Present in a Large Proportion of Simple Bone Cysts. Am. J. Surg. Pathol. 2020, 44, 1623-1634. [CrossRef]

183. Richkind, K.E.; Mortimer, E.; Mowery-Rushton, P.; Fraire, A. Translocation (16;20)(p11.2;q13). sole cytogenetic abnormality in a unicameral bone cyst. Cancer Genet. Cytogenet. 2002, 137, 153-155. [CrossRef]

184. Mulliken, J.B.; Glowacki, J. Hemangiomas and vascular malformations in infants and children: A classification based on endothelial characteristics. Plast. Reconstr. Surg. 1982, 69, 412-422. [CrossRef] [PubMed]

185. Steele, L.; Zbeidy, S.; Thomson, J.; Flohr, C. How is the term haemangioma used in the literature? An evaluation against the revised ISSVA classification. Pediatr. Dermatol. 2019, 36, 628-633. [CrossRef] [PubMed]

186. Enjolras, O.; Mulliken, J.B. Vascular tumors and vascular malformations (new issues). Adv. Dermatol. 1997, 13, 375-423. [PubMed]

187. Flucke, U.; Karanian, M.; Broek, R.W.T.; Thway, K. Soft Tissue Special Issue: Perivascular and Vascular Tumors of the Head and Neck. Head Neck Pathol. 2020, 14, 21-32. [CrossRef] [PubMed]

188. Arbajian, E.; Magnusson, L.; Brosjö, O.; Wejde, J.; Folpe, A.L.; Nord, K.H.; Mertens, F. A benign vascular tumor with a new fusion gene: EWSR1-NFATC1 in hemangioma of the bone. Am. J. Surg. Pathol. 2013, 37, 613-616. [CrossRef] [PubMed] 